Portland State University

PDXScholar

$1-1-2012$

\title{
Reservoir Evolution Following the Removal of Marmot Dam on the Sandy River, Oregon
}

Mackenzie Karli Keith

Portland State University

Follow this and additional works at: https://pdxscholar.library.pdx.edu/open_access_etds Let us know how access to this document benefits you.

\section{Recommended Citation}

Keith, Mackenzie Karli, "Reservoir Evolution Following the Removal of Marmot Dam on the Sandy River, Oregon" (2012). Dissertations and Theses. Paper 532.

https://doi.org/10.15760/etd.532

This Thesis is brought to you for free and open access. It has been accepted for inclusion in Dissertations and Theses by an authorized administrator of PDXScholar. Please contact us if we can make this document more accessible: pdxscholar@pdx.edu. 
Reservoir Evolution Following the Removal of

Marmot Dam on the Sandy River, Oregon

by

Mackenzie Karli Keith

A thesis submitted in partial fulfillment of the requirements for the degree of

\author{
Master of Science \\ in \\ Geology
}

Thesis Committee:

Andrew Fountain, Chair

Scott Burns

Jon Major

James O’Connor

Portland State University

(C) 2012 


\begin{abstract}
The October 2007 removal of Marmot Dam, a 14.3-m-tall dam on the Sandy River in northwestern Oregon storing approximately 730,000 $\mathrm{m}^{3}$ of impounded sediment, provided an opportunity to study short- and long-term geomorphic effects of dam removal. Monitoring reservoir morphology during the two years following dam decommissioning yields a timeline of reservoir channel change. Comparison of a predam survey in 1911 with post-removal surveys provides a basis from which to gage the Reservoir Reach evolution in the context of pre-dam conditions. Analyses of time-lapse photography, topographic surveys, and repeat LiDAR data sets provide detailed spatial and temporal documentation of a release of sediment from the reservoir following dam removal.
\end{abstract}

The majority of morphologic changes to the reservoir largely took place during the first few days and weeks following removal. Channel incision and widening, along with gradient changes through the Reservoir Reach, exhibit diminishing changes with time. Channel incision rates of up to $13 \mathrm{~m} / \mathrm{hr}$ and widening rates of up to $26 \mathrm{~m} / \mathrm{hr}$ occurred within the first 24 hours following breaching of the coffer dam. Although channel position through the Reservoir Reach has remained relatively stable due to valley confinement, its width increased substantially. The channel reached an average width of $45 \mathrm{~m}$ within two weeks of breaching, but then erosion rates slowed and the channel width reached about 70 to $80 \mathrm{~m}$ after one and two years, respectively. Diminishing volumes of evacuated sediment were measured over time through quantitative analysis of survey 
datasets. About 15 percent of the initial impounded sediment was eroded from the Reservoir Reach within 60 hours of breaching; after one and two years, 50 and 58 percent was eroded, respectively. Grain-size analysis of terraces cut into reservoir fill following dam removal show that bed material coarsened over time at fixed elevations and vertically downward as the channel incised.

Overall, these findings indicate valley morphology and local in-channel bedrock topography controlled the spatial distribution of sediment within the reservoir reach while variability in river discharge determined the timing of episodic sediment release. Changes within the Reservoir Reach shortly after dam removal and subsequent evolution over the two years following removal are likely attributable to 1 ) the timing and intensity of flow events, 2) the longitudinal and stratigraphic spatial variations in deposit grain-size distributions initially and over time, and 3) the pre-dam topography and existing valley morphology. 


\section{Acknowledgements}

I would like to express my gratitude to all those who gave me the possibility to complete this thesis. First and foremost, I would like to thank God for His source of strength and for providing challenges and the tools to address those challenges.

I would like to acknowledge and thank my advisers and committee, Andrew Fountain, Jim O’Connor, Jon Major, and Scott Burns, for their direction and support throughout my project. Jim and Jon shared their wisdom and provided invaluable guidance through their mentoring. Andrew provided valuable feedback that has improved this thesis.

I would like to thank Portland General Electric, especially David Heintzman and John Esler, for allowing unlimited site access and providing data about Marmot Dam.

I would like to thank Rose Wallick and Chuck Podolak for their knowledgeable advice during the many phases of this project.

This thesis would not have been possible without the time of energy of those who have contributed to field-based data collection including: Jon Major, Jim O’Connor, Rose Wallick, Kurt Spicer, Tami Christianson, Becca Collins, Abbey Rhode, JoJo Mangano, Charlie Cannon, Dan Polette , Cole Kingsbury, Dwight Tanner, and Krista Jones (USGS); Barbara Burkholder (Oregon State University); Chuck Podolak (Johns Hopkins University); a team of 2009 NCED undergraduate interns, especially Diana DiLeonardo; Paul Pedone (NRCS); and Xavi Rodriguez Lloveras (National Museum of Natural Science, Spanish Research Council, Spain).

I would also like to thank my family for their love and encouragement. 


\section{Table of Contents}

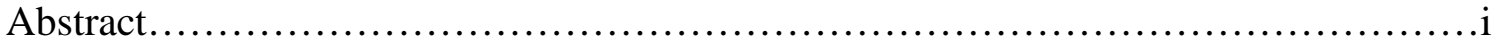

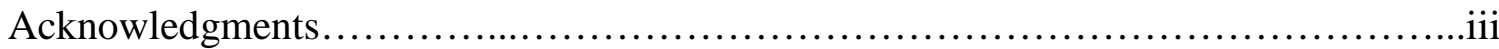

List of Tables.........................................................................

List of Figures.....................................................................

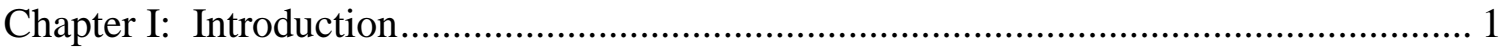

U.S. dam removal and the consequences and benefits of dam removal .......................2

Previous work on the upstream changes following dam removal ..............................5

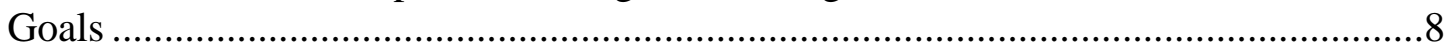

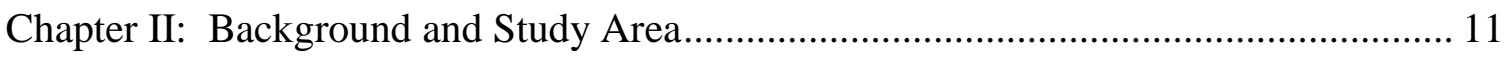

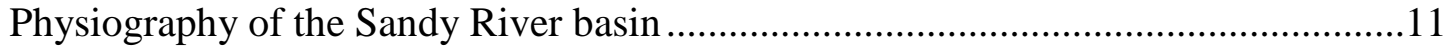

Hydrology and climate of the Sandy River basin .................................................13

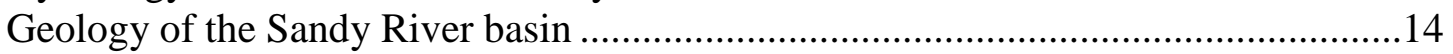

Sedimentation in the Sandy River.......................................... 18

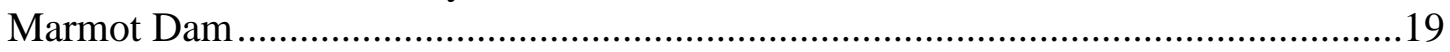

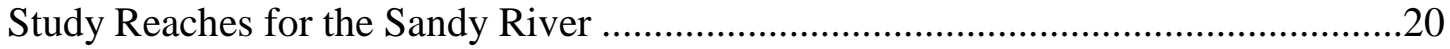

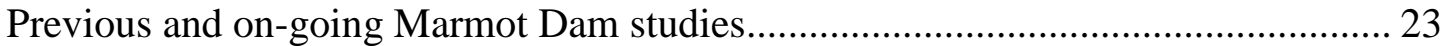

Chapter III: Pre-dam Channel Morphology .................................................................. 25

Chapter IV: Post-dam Vertical and Horizontal Changes in Channel Morphology ......... 34

Methods to measure channel changes during and immediately following breaching .34

Methods to measure channel changes 2 weeks to 2 years following dam removal.....40

Channel changes during and immediately following breaching ............................... 43

Channel changes 2 weeks to 2 years following dam removal .................................47

Reservoir Reach erosion volume change and rate ................................................ 56

Chapter V: Reservoir Erosion and Volume Change...............................53

Chapter VI: Changes in Bed Material and Bar Morphology ........................................ 62

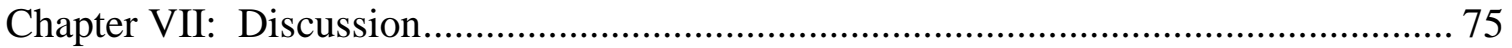

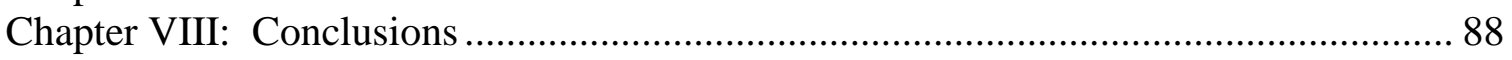

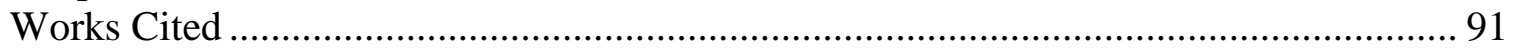

Appendix A. Resources and links to other Marmot Dam related studies..................... 102

Appendix B. Photogrammetry model results obtained with PhotoModeler and repeat

time lapse photography of the Marmot Dam reservoir............................................ 104

Appendix C. Grain sizes and statistics obtained from transects in the vicinity of Marmot

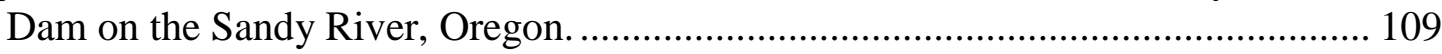




\section{List of Tables}

Table 1. Examples of dams that have been removed or are pending removal including dam height and stored sediment volume........................................................................ 3

Table 2. Summary of geologic events impacting the Sandy River, 50 Ma to present...... 15

Table 3. Reservoir and Beaver Island reach conditions prior to the removal of Marmot

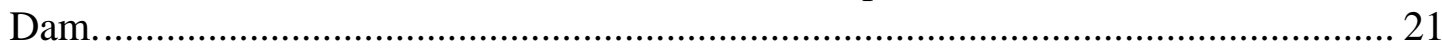

Table 4. Summary of data used to detect changes upstream of the former Marmot Dam on the Sandy River, Oregon, including sources, collection dates, scales, and mean daily discharges at collection dates.......................................................................... 41

Table 5. Reservoir erosion volumes following the removal of Marmot Dam on the Sandy

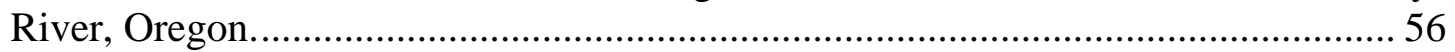

Table 6. Grain size classes used to bin particle count data.......................................... 64

Table 7. Attributes of the Stronach Dam on the Pine River, Michigan and Marmot Dam on the Sandy River, Oregon that may explain different post-removal reservoir evolution. 


\section{List of Figures}

Figure 1. Photograph of Marmot Dam, Sandy River, Oregon (courtesy of Portland

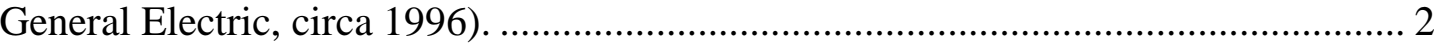

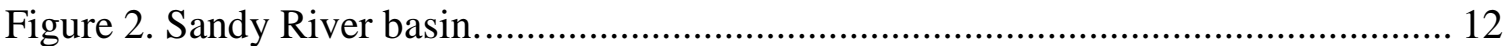

Figure 3. Peak discharge record at USGS streamflow-gaging station 14137000 Sandy

River near Marmot, Oregon, and flood frequency data (Cooper, 2005).................... 14

Figure 4. Aerial photograph of study area in the vicinity of Marmot Dam, Sandy River,

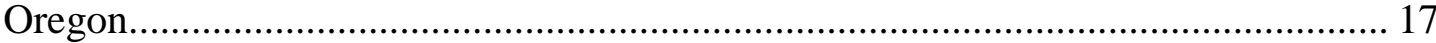

Figure 5. Major components of the Bull Run Hydroelectric Project operated by Portland General Electric. The project was decommissioned and Roslyn Lake was drained by 2008.

Figure 6. Schematic of the Marmot Dam reservoir deposit stratigraphy on the Sandy River, Oregon, extending about $1.5 \mathrm{~km}$ upstream of the dam site. Adapted from Squier Associates (2000). Not to scale.

Figure 7. A) Mosaic of 1911 pre-dam topographic planning map (unknown datum) for Marmot Dam on the Sandy River, Oregon. B) Area of detail at Beaver Island. (PGE, 1911)

Figure 8. Surface created from 1911 historical topographic map of the Sandy River, Oregon, in the vicinity of Marmot Dam.

Figure 9. Longitudinal profiles extracted from 1911 interpolated TIN surface, the top of Squier Associates’ (2000) Unit 3 (pre-dam bed surface), and the 2007 and 2008 LiDAR digital elevation models of the Sandy River reservoir area.

Figure 10. Comparison of 1911 pre-dam surface cross-sections with those of pre- and post-removal cross sections within the reservoir surveyed by David Evans and Associates. Locations at A) 850 m, B) 620 m, C) 180 m, and D) 20 m upstream of the coffer dam location.

Figure 11. Notes (A) and map (B) from a General Land Office survey conducted in 1860 and (C) a 2009 aerial photograph with red dot denoting the location referred to in the notes.

Figure 12. Locations of camera stations and points of view from these locations. Orange targets visible in photographs were used to provide control in PhotoModeler processing. Arrows indicate direction of camera view. A) Camera 1, view downstream from left bank in reservoir, B) Camera 2, view downstream from left bank in reservoir with dam-hazard sign visible in lower right-hand corner of photograph, C) Camera 3, view upstream near pedestrian bridge below the dam site, D) Camera 5, view upstream from right bank in reservoir with dam-hazard sign visible near center of photograph, and E) Camera 4, view downstream from right bank in reservoir.

Figure 13. PhotoModeler creates a model based on coincident points between photographs. This example shows where rays from cameras 2 and 5 would intersect the orange photograph targets. Yellow circles indicate the location of targets within the terrestrial photographs 
Figure 14. Mean daily discharge from USGS streamflow-gaging station 14137000, Sandy River near Marmot, Oregon and timing of USGS topographic surveys over the twoyear period following the removal of Marmot Dam on 19 October, 2007.

Figure 15. Sandy River water-surface profiles for the lower reservoir derived from photogrammetry for about A) 2 hours, B) 1 day, and C) 3 days following coffer dam breaching which occurred at 1700 PST on 19 October 2007.

Figure 16. Hydrograph at USGS streamflow-gaging station 14137000 following coffer dam breaching on the Sandy River, Oregon (USGS, 2009b).

Figure 17. Net change in elevation at four locations measured from time lapse photography following the removal of Marmot Dam on the Sandy River, Oregon. Dates represent the end of the day unless noted. Due to camera station moves, the stations $56 \mathrm{~m}$ downstream and $8 \mathrm{~m}$ upstream of the dam site were only measured through 25 October, 2007, while those at $43 \mathrm{~m}$ and $81 \mathrm{~m}$ upstream of the dam site were monitored through 5 November.

Figure 18. Channel width measured photogrammetrically following breaching of the coffer dam $8 \mathrm{~m}$ upstream the dam site. The initial width is the un-channeled, wetted width prior to coffer dam breaching.

Figure 19. Longitudinal profiles of water-surface elevation in the vicinity of the former Marmot Dam on the Sandy River, Oregon, as measured from LiDAR and field surveys.

Figure 20. Water-surface elevation during the 2 years following the removal of Marmot Dam on the Sandy River, Oregon.

Figure 21. Active channel width within the Reservoir Reach following the removal of Marmot Dam. 50 Figure 22. Cumulative reservoir erosion and downstream deposition two years following the removal of Marmot Dam including variation in discharge and collection dates for USGS and LiDAR surveys used to measure the change in volume. 57

Figure 23. Select annual David Evans and Associates cross sections at A) 20 m, B) 410 $\mathrm{m}$, C) $620 \mathrm{~m}$, D) $850 \mathrm{~m}$, E) 1,290 m, and F) 2,180 m upstream of the coffer dam site. Data from DEA (2005, 2006, 2007, 2008, 2009, 2010).

Figure 24. Outline of distinct reservoir bar surfaces mapped from aerial photography and LiDAR for A) pre-removal of Marmot Dam in 2007 and B) post-removal, about one year later in 2008. Reservoir bed-material surface sampling sites are shown on B and colored by median grain size. The point locations represents the upstream coordinate of transect.

Figure 25. Median grain size of bed-material samples collected in the Reservoir Reach relative to height above the 2008 LiDAR water surface in the Reservoir Reach of the Sandy River. See appendix C for sample location.

Figure 26. Pre- and post-removal LiDAR cross sections in the Reservoir Reach at about $250 \mathrm{~m}$ upstream of the dam site. These sections illustrate terrace development and bed-material coarsening following dam removal. Terraces are also labeled on Figure 27 
Figure 27. Photograph of bedrock and remaining sediment relative to channel position in the Reservoir Reach of the Sandy River following dam removal. Terrace locations

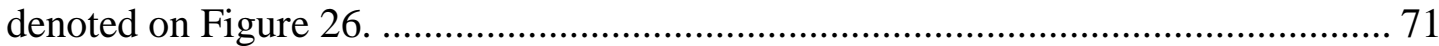
Figure 28. Particle-size distributions of bed-material samples collected in the Reservoir Reach of the Sandy River following removal of Marmot Dam. See appendix C for sample location. 


\section{Chapter I: Introduction}

On 19 October 2007, a temporary coffer dam constructed to aid the removal of the Marmot Dam on the Sandy River, Oregon, was breached. Consequently, the Sandy River rapidly incised and widened a channel through approximately 730,000 $\mathrm{m}^{3}$ of impounded sand and gravel which had nearly filled the reservoir to the dam's crest. Exposed reservoir sediment was subject to further erosion, transport, and downstream deposition in the months and years after breaching. After 94 years of obstruction, flow on the Sandy River was once again unimpeded, allowing the river to follow a more natural course.

The14.3-m-tall, approximately 60-m-wide Marmot Dam (Figure 1) was a diversion dam completed in 1913 and utilized as part of Portland General Electric’s (PGE) Bull Run Hydroelectric Project. In May 1999, a decision was made to surrender the Federal Energy Regulatory Commission (FERC) operating license prior to its expiration in 2004 and remove the dam (PGE, 1999; Esler, 2009). Approximately 750,000 $\mathrm{m}^{3}$ uncontaminated sediment filled the reservoir, and concerns arose regarding

how that sediment would migrate downstream. PGE opted to remove the dam rapidly, within a few months and with minimal sediment excavation, a scenario informally termed the "blow and go" option. This option minimized the environmental impacts of working in the river with construction equipment to remove the sediment over multiple seasons. In terms of dam size and sediment volume retained, Marmot Dam is one of the largest dams to be removed in the United States and was the largest in the Pacific Northwest at 
the time of removal. Most other removals nationwide had reservoir sediment volumes of less than 125,000 $\mathrm{m}^{3}$ (Heinz Center, 2002).

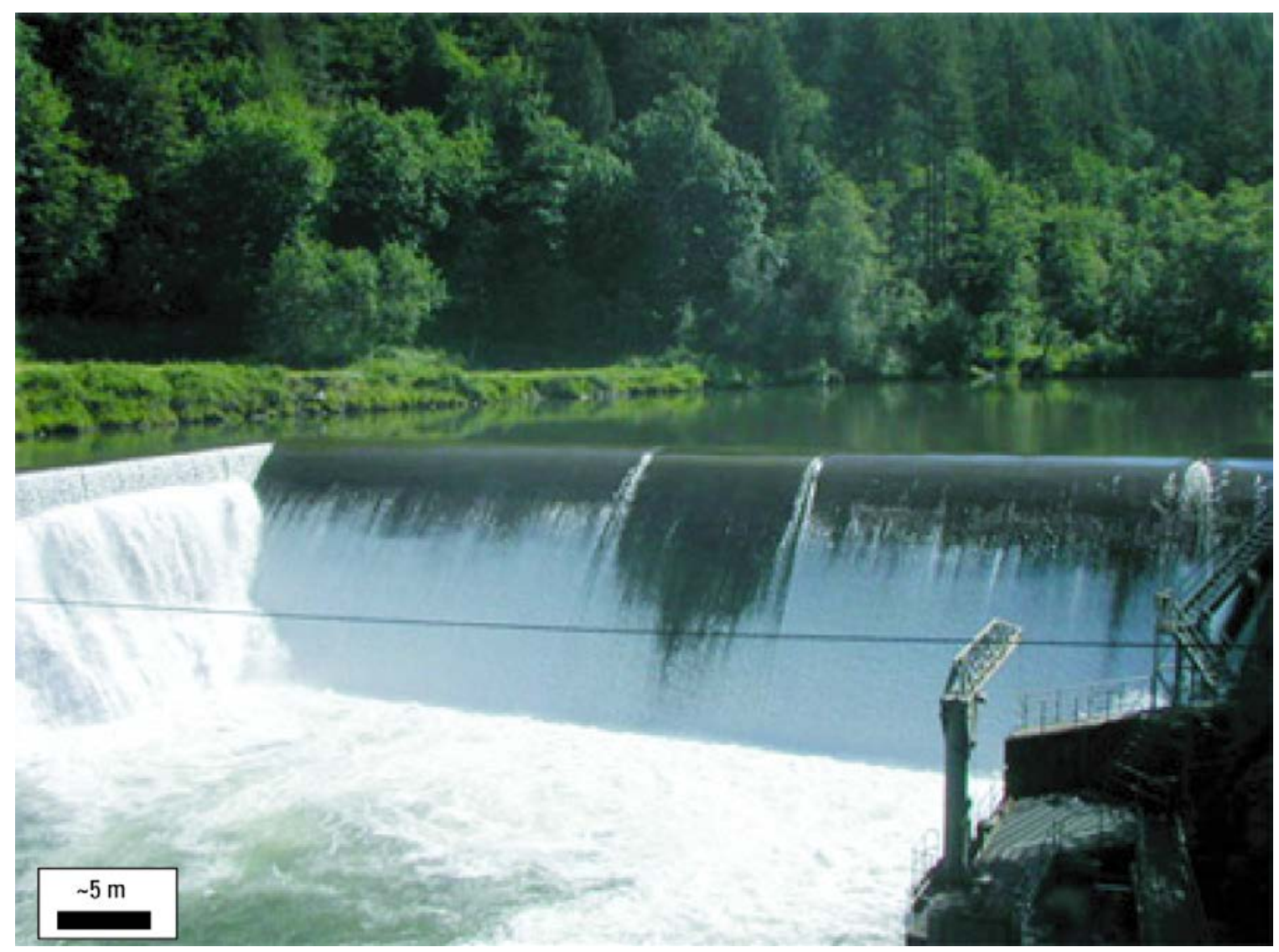

Figure 1. Photograph of Marmot Dam, Sandy River, Oregon (courtesy of Portland General Electric, circa 1996).

U.S. dam removal and the consequences and benefits of dam removal

An increasing number of medium to large dams, categorized as having stored sediment volumes of 125,000 $\mathrm{m}^{3}$ to $12,000,000 \mathrm{~m}^{3}$, (Heinz Center, 2002) are being considered for removal. At the time of its removal, the reservoir at Marmot Dam stored more sediment than most dams that had been removed. However, proposed 
decommissioning for removal of larger dams (in terms of sediment stored) were already planned (e.g. Glines Canyon Dam, Washington) or imminent (e.g. Milltown Dam, Montana; Table 1).

Table 1. Examples of dams that have been removed or are pending removal including dam height and stored sediment volume. [Abbreviations: m, meters; $\mathbf{m}^{3}$, cubic meters]

\begin{tabular}{|c|c|c|c|c|c|}
\hline Dam & River & $\begin{array}{l}\text { Construction } \\
\text { Date }\end{array}$ & $\begin{array}{l}\text { Removal } \\
\text { Date }\end{array}$ & $\begin{array}{l}\text { Dam } \\
\text { Height } \\
\text { (m) }\end{array}$ & $\begin{array}{c}\text { Stored } \\
\text { Sediment } \\
\text { Volume }\left(\mathrm{m}^{3}\right)\end{array}$ \\
\hline Rockdale & Koshkonong, Wisconsin & 1846 & 2000 & 2.4 & 290,000 \\
\hline LaValle & Baraboo River, Wisconsin & 1848 & 2000 & 3.3 & 140,000 \\
\hline Stronach & Pine River, Michigan & 1912 & 2003 & 4.6 & 790,000 \\
\hline Marmot Dam & Sandy River, Oregon & 1913 & 2007 & 14.3 & 750,000 \\
\hline Chiloquin & Sprague River, Oregon & 1914 & 2008 & 3.4 & $61,000 *$ \\
\hline Gold Hill & Rogue River, Oregon & 1944 & 2008 & 4.3 & 0 \\
\hline Milltown & $\begin{array}{l}\text { Black Foot and Clark } \\
\text { Fork Rivers, Montana }\end{array}$ & 1907 & 2008 & 9.1 & 230,000 \\
\hline Savage Rapids & Rogue River, Oregon & 1921 & 2009 & 11.9 & 150,000 \\
\hline Gold Ray & Rogue River, Oregon & 1904 & 2010 & 11.6 & 310,000 \\
\hline Elwha & Elwha River, Washington & 1913 & 2011 & 32.0 & $3,000,000$ \\
\hline Condit & $\begin{array}{l}\text { White Salmon River, } \\
\text { Washington }\end{array}$ & 1913 & 2011 & 38.1 & $2,060,000$ \\
\hline Glines Canyon & Elwha River, Washington & 1927 & 2011 & 64.0 & $15,600,000$ \\
\hline Copco No. 2 & Klamath River, California & 1925 & Pending & 10.1 & 0 \\
\hline J.C. Boyle & Klamath River, Oregon & 1958 & Pending & 20.7 & 490,000 \\
\hline Copco No. 1 & Klamath River, California & 1918 & Pending & 38.4 & $8,320,000$ \\
\hline Iron Gate & Klamath River, California & 1962 & Pending & 52.7 & $6,790,000$ \\
\hline Matijila & Matilija Creek, California & 1947 & Pending & 60.3 & $4,590,000$ \\
\hline
\end{tabular}

*Value in metric tons

More than 83,000 dams (USACE, 2009) in the United States meet one or more of the following criteria: 1) a high hazard classification where the loss of one human life is likely if the dam fails, 2) a significant hazard classification where there is possible loss of human life and likely significant property or environmental damage, 3) is taller than $2 \mathrm{~m}$ and has a reservoir storage capacity of more than $62,000 \mathrm{~m}^{3}$, or 4 ) is taller than $8 \mathrm{~m}$ and has a reservoir storage capacity of more than 19,000 $\mathrm{m}^{3}$ (Graf, 1999). Inventories show 
that the number of medium to large removals in the United States was minimal prior to the 1970’s, but has jumped considerably in the following decades (Pohl, 2003).

The decision to decommission a dam can be motivated by many factors, including: relicensing; dam safety; maintenance and upgrade costs; economic, social and political reasons; or biological concerns (Aspen Institute, 2000; Doyle and others, 2000; Heinz Center, 2002; Poff and Hart, 2002; American Rivers and Trout Unlimited, 2002; Graf, 2005). PGE opted to remove Marmot Dam, at a cost of 17 million dollars (PGE, 2002), prior to relicensing because anticipated project operation, maintenance, and fish passage upgrade costs outweighed projected operational revenue (Esler, 2009). The dominant concerns surrounding any dam removal typically revolve around the biophysical and social consequences (Doyle and others, 2000; Heinz Center, 2002), and the potential physical changes to the fluvial system associated with altering the sediment and hydrologic regime (Pizzuto, 2002; Heinz Center, 2002). Possible consequences associated with dam removal may include reduction of channel complexity in reaches downstream of the dam negatively affecting ecosystem function (Doyle and others, 2000), changes in geomorphic conditions such as altered grain sizes and channel geometry (Heinz Center, 2002; Graf, 2003; Grant and others, 2003) and flash flooding (Heinz Center, 2002).

In the case of Marmot Dam, the principal concerns identified by government agencies, non-governmental organizations, and the public included potential reduction in channel complexity and channel and habitat connectivity due to sedimentation (PGE, 
2002; FERC, 2003). Temporal and spatial patterns of sediment evacuation from the reservoir could affect anadromous salmonid passage and habitat. Flooding was not a principal concern for the removal of Marmot Dam because of the small volume of water retained, basin topography, and absence of residential property immediately downstream of the dam site (Stillwater Sciences, 2000a,b; FERC, 2003).

Monitoring the fluvial adjustments and associated physical processes following dam removal can help make informed decisions about future dam removals. An increased understanding of how the fluvial system evolves following removal will likely improve future decisions with regard to biological, economic, and social impacts. Little research has been done to document a river's response to large removals, and little quantitative information is available concerning the rate of erosional processes that occur within a reservoir reach following dam removal.

Previous work on the upstream changes following dam removal

Documented changes associated with reservoir erosion following dam removal come chiefly from observations following small, relative to the height of or volume of sediment retained by Marmot Dam, dam removals, which can vary in hydrologic, sediment, physiographic, or climatic regime. Because the geomorphic processes that follow a dam's removal occur in all river systems (Pizzuto, 2002), an understanding of fundamental geomorphic principles (e.g., Leopold and others, 1964; Charlton, 2008) can be used to develop conceptual models of potential responses to dam removal. Doyle and others (2002) suggest the use of channel-evolution models when addressing reach-scale 
channel changes resulting from dam removal. They describe five stages in which a reservoir reach may respond to dam removal: water lowering, incision, incision and widening, aggradation and widening, and quasi-equilibrium.

For example, Doyle and others (2003a) observed that fluvial responses following removal of two dams on Wisconsin rivers included bed degradation, channel incision downstream of a headcut, deposition of incised material on the marginal floodplain downstream of incision, and bank erosion that was limited by the deposition on the marginal floodplain or by cohesive banks. They also showed that erosion of impounded sediment upstream of a dam removal can be rapid, but the rates are largely dependent upon grain-size characteristics of the impounded sediment. Knickpoint migration following the removal of two small dams in Oregon showed that upstream retreat was largely determined by river discharge and the grain size of the impounded sediment (Stewart and Grant, 2005; Stewart, 2006).

Expected channel evolution following dam removal can also be drawn from studies of geomorphic analogies, such as sediment loading due to landslides, hillslope erosion, or floods (Madej and Ozaki, 1996; Sutherland and others 2002; Brummer and Montgomery, 2006; Hoffman and Gabet, 2007; Lancaster and others, 2010) or volcanic eruptions (Simon, 1999; Major and others, 1996; Major and others, 2004; Gran and Montgomery, 2005; Pierson and others, 2011). For example, Hoffman and Gabet (2007) observed that incision through debris-flow sediment deposited in a channel developed 
coarse-grained terraces. After removal, coarsening is likely to occur in the reservoir as finer particles are more readily transported downstream.

Physical modeling of dam removal using scaled flume experiments or field-based, larger scale controlled dam breaches can offer insights that may be useful for a specific case study. Flume experiments show channel incision and widening through impounded sediment following dam removal can happen quickly (Cantelli and others, 2004). A scaled physical model of Marmot Dam showed that the knickpoint retreat might be controlled by the position of the notch cut into the coffer dam to allow breaching and that positioning of the notch affected erosion rates and patterns (Marr and others, 2007; Grant and others, 2008).

Numerical modeling is useful for examining conditions not easily or inexpensively replicated in nature. However, numerical models are limited to our understanding of the underlying physics and the assumptions associated with a particular model. Modeling has proven to be an effective means of assessing potential temporal and spatial variation of sediment transport (Cui and Wilcox, 2008). For Marmot Dam, Stillwater Sciences (2000a,b) used a one-dimensional model to predict change in reservoir sediment thickness and stream gradient. Results showed reservoir erosion of 3 m, $4 \mathrm{~m}$, and $5 \mathrm{~m}$ after 30 days, 60 days and 1 year following removal. The stream gradient was expected to reach an average of $0.007 \mathrm{~m} / \mathrm{m}$ in the lower $1 \mathrm{~km}$ of the Reservoir Reach after one year (Stillwater Sciences, 2000a,b; Cui and Wilcox, 2008; Cui and others, 2011) and an average of 0.005 to $0.006 \mathrm{~m} / \mathrm{m}$ after ten years. 
The physical and numerical modeling and case studies of dam removal suggest the following sequence of events occur in the reservoir reach following dam removal. 1) The river incises a channel through the unconsolidated deposit. 2) The longitudinal profile of the stream adjusts as the knickpoint retreats and sediment is transported from upstream to downstream. 3) Bank collapse follows deep incision resulting in channel widening. 4) The grain-size distribution of the reservoir sediment coarsens. I recognize that these processes will occur in some form with the removal of Marmot Dam. However, given the large sediment deposit in place, the magnitude and rates of change may differ significantly from earlier smaller dam removal events.

\section{Goals}

The research goal for this project is to characterize, quantitatively and qualitatively, the changes that occurred upstream of the Marmot Dam following removal and to define the underlying factors that drive those changes. Results of this research are applicable not only to dam removal, but also to a broad range of fluvial responses including natural dam breaks, rapid adjustments to local base level, and floods.

The study of the response of the Sandy River to the Marmot Dam removal was a large collaborative effort of several government agencies, universities, and private consulting firms. Collaborators include the U.S. Geological Survey, Johns Hopkins University, Stillwater Sciences, U.S. Forest Service, Oregon State University, Graham Matthews and Associates, U.S. Bureau of Reclamation, and other private firms commissioned by PGE. See Appendix A for references and links to other and ongoing 
Marmot Dam related research. My research focuses on the processes and morphologic changes occurring in two reaches of the river, mainly the 'Reservoir Reach,' defined as extending approximately $3.5 \mathrm{~km}$ upstream of the dam. The 'Beaver Island Reach,' extending $2 \mathrm{~km}$ downstream of the dam site, is briefly discussed in the pre-dam context (Chapter III) and as a depositional system related to reservoir erosion (Chapter V). To support the overall research goal, six objectives were identified to document channel response:

1. Reconstruct pre-dam conditions from historical data. This includes qualitative descriptions of the pre-dam channel as well as physical records of topography within the study area.

2. Measure the temporal and spatial evolution of the horizontal and vertical channel-pattern adjustments as well as bar formation following dam removal in the Reservoir Reach.

3. Characterize post-removal changes in the grain-size distributions of surface and subsurface bed material throughout the study area and relate the textural variation to changes in reservoir morphology.

4. Calculate the volume of sediment eroded from the reservoir impoundment following dam removal and the amount deposited in the reach immediately downstream of the dam site over time. 
5. Compare changes in channel condition to historical form and address how these changes compare to changes predicted by a one-dimensional sediment transport model.

6. Identify dominant controls on the system that explain the nature of the physical changes and the implications these controls might have for other dam removals.

My field work included topographic surveying between January 2008 and September 2009 and collecting surface and subsurface bulk sediment samples. I processed five of the eight topographic surveys collected by the U.S. Geological Survey and one of three bulk sediment samples collected by National Center for Earth-surface Dynamics (NCED) interns and the U.S. Geological Survey. Evolution of the Reservoir Reach following dam removal is quantified by repeat photogrammetry, repeat groundbased surveys, light detection and ranging (LiDAR) topographic data, and sediment grain-size analysis of bed material. Historical data was used to place post-dam-removal channel development into context with its pre-dam state.

This project is divided into three distinct temporal stages: 1) the pre-dam era and time shortly after dam construction, 2) the first two weeks following dam removal, and 3) the two year period following removal. Dividing the study into these time periods clarifies how the river has changed and may continue to change. It allows for better identification, description, and explanation of the distinct phases of evolution, and permits a linkage of river changes to driving factors. 


\section{Chapter II: Background and Study Area}

Physiography of the Sandy River basin

The Sandy River originates on the west-southwest slopes of Mount Hood (elevation 3,642 m) with its headwaters located at 1,800 m elevation near the Reid and Sandy glaciers. The river drains 1,300 $\mathrm{km}^{2}$ (Figure 2) and traverses $90 \mathrm{~km}$ of the High and Western Cascades physiographic provinces (Orr and Orr, 2000) before reaching its confluence with the Columbia River (elevation $\sim 3 \mathrm{~m}$ ). The drainage area is $680 \mathrm{~km}^{2}$ at the Marmot Dam site.

From its source, the Sandy River flows about $4 \mathrm{~km}$ through steep, narrow canyons cut into a debris fan on the flanks of Mount Hood. At $4 \mathrm{~km}$, the river valley broadens to over 800 meters in most places, and river gradient decreases to $0.05 \mathrm{~m} / \mathrm{m}$ through Old Maid Flats, near the confluence with Clear Creek and Zigzag River. The Holocene floodplain narrows slightly to an average of 200 m near Brightwood, where the Salmon River joins the Sandy River. Downstream of Alder Creek at about $35 \mathrm{~km}$ from its headwaters, the channel valley again becomes constricted, and the confluence with Whisky Creek marks the approximate upstream extent of Marmot Dam Reservoir Reach. Below the dam site, the Sandy River valley widens for a short distance before entering the steep $(0.008 \mathrm{~m} / \mathrm{m})$, and narrow 6.4-km-long Sandy River gorge where floodplain widths average $35 \mathrm{~m}$. Between the gorge and the confluence of the Bull Run River at Dodge Park, the floodplain once again widens to an average $190 \mathrm{~m}$ and channel gradient decreases $(0.007 \mathrm{~m} / \mathrm{m})$. The Sandy River flows through confined and unconfined reaches 


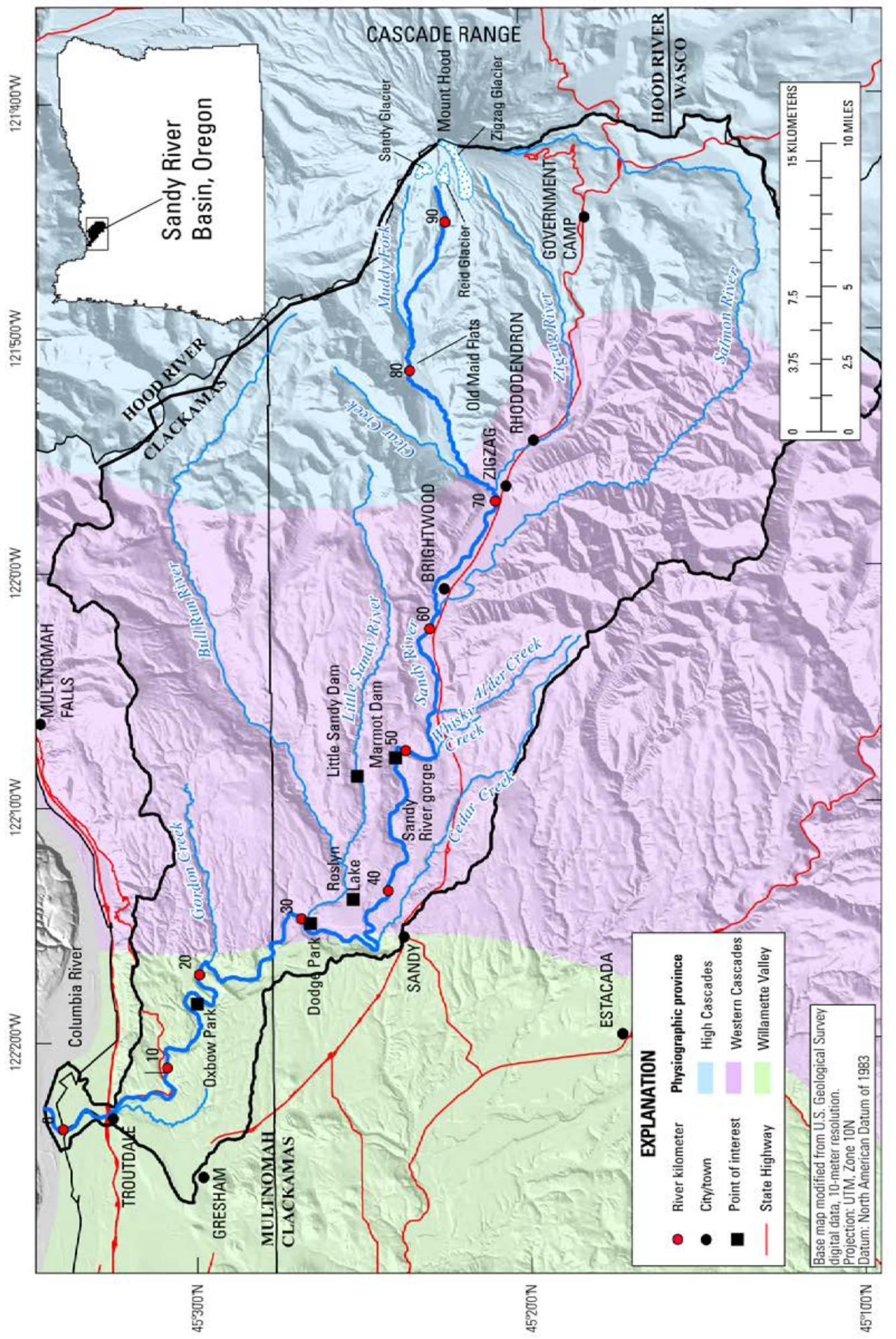

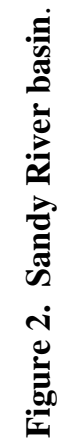


(average floodplain width is $240 \mathrm{~m}$ ) below Dodge Park to its confluence with the Columbia River. At the Sandy River’s mouth near Troutdale, a $10 \mathrm{~km}^{2}$ prograding delta protrudes into the Columbia River (Figure 2).

Hydrology and climate of the Sandy River basin

The Sandy River basin has a Mediterranean climate with cool, moist winters and warm, dry summers. Mean annual high and low temperatures near the dam site are 15.6 ${ }^{\circ} \mathrm{C}$ and $5{ }^{\circ} \mathrm{C}$, respectively (PRISM, 2009). Mean annual precipitation ranges from 2,700 $\mathrm{mm}$ at the headwaters to $700 \mathrm{~mm}$ at the mouth. Mean annual precipitation is about 1,970 mm near the dam site (PRISM, 2009). Peak annual discharges (Figure 3) are typically produced by winter rain-on-snow events or by spring snow melt. The mean annual flow at the dam site is approximately $40 \mathrm{~m}^{3} / \mathrm{s}$ (USGS, 2009b) and the 5-year recurrence interval discharge is $632 \mathrm{~m}^{3} / \mathrm{s}$ (Cooper, 2005). The maximum recorded discharge for the Sandy River at USGS streamflow-gaging station 14137000 Sandy River near Marmot, Oregon was 1,739 m³ $/ \mathrm{s}$ on 22 December, 1964. While the Bull Run Hydroelectric Project was operational, PGE diverted 11 to $17 \mathrm{~m}^{3} / \mathrm{s}$ of flow from the Sandy River at Marmot Dam; however, this amount varied with seasonal discharge and minimum instream flow requirements (PGE, 1999). 


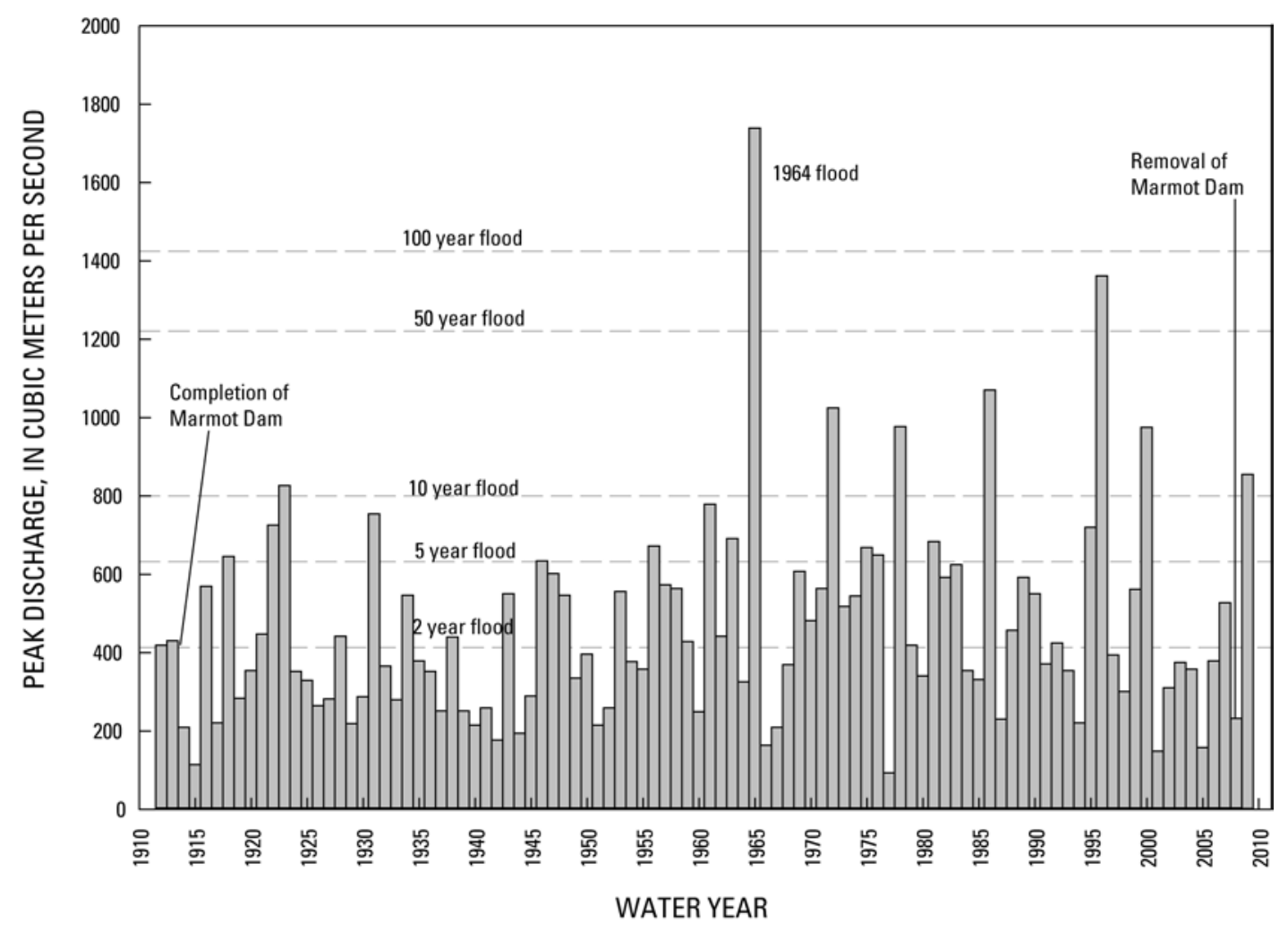

Figure 3. Peak discharge record at USGS streamflow-gaging station 14137000 Sandy River near Marmot, Oregon, and flood frequency data (Cooper, 2005).

Geology of the Sandy River basin

During the late Miocene (14 to $11 \mathrm{Ma}$ ) a series of volcaniclastic rich lahars, now composing the Rhododendron Formation, were deposited in the Western Cascades (Table 2). The Rhododendron Formation is present through the Reservoir and Beaver Island reaches and forms steep canyon walls (Barnes and Butler, 1930; Wise, 1969; Scott and others, 1997). The Rhododendron Formation is highly erodible where few clasts are present but fairly resistant where abundant andesitic clasts, varying in size, shield ashy matrix material from erosion, such as at dam site (Scott and others, 1997). Later Pliocene (2 to $5 \mathrm{Ma}$ ) andesitic flows (Table 2) are also present throughout the study area. 


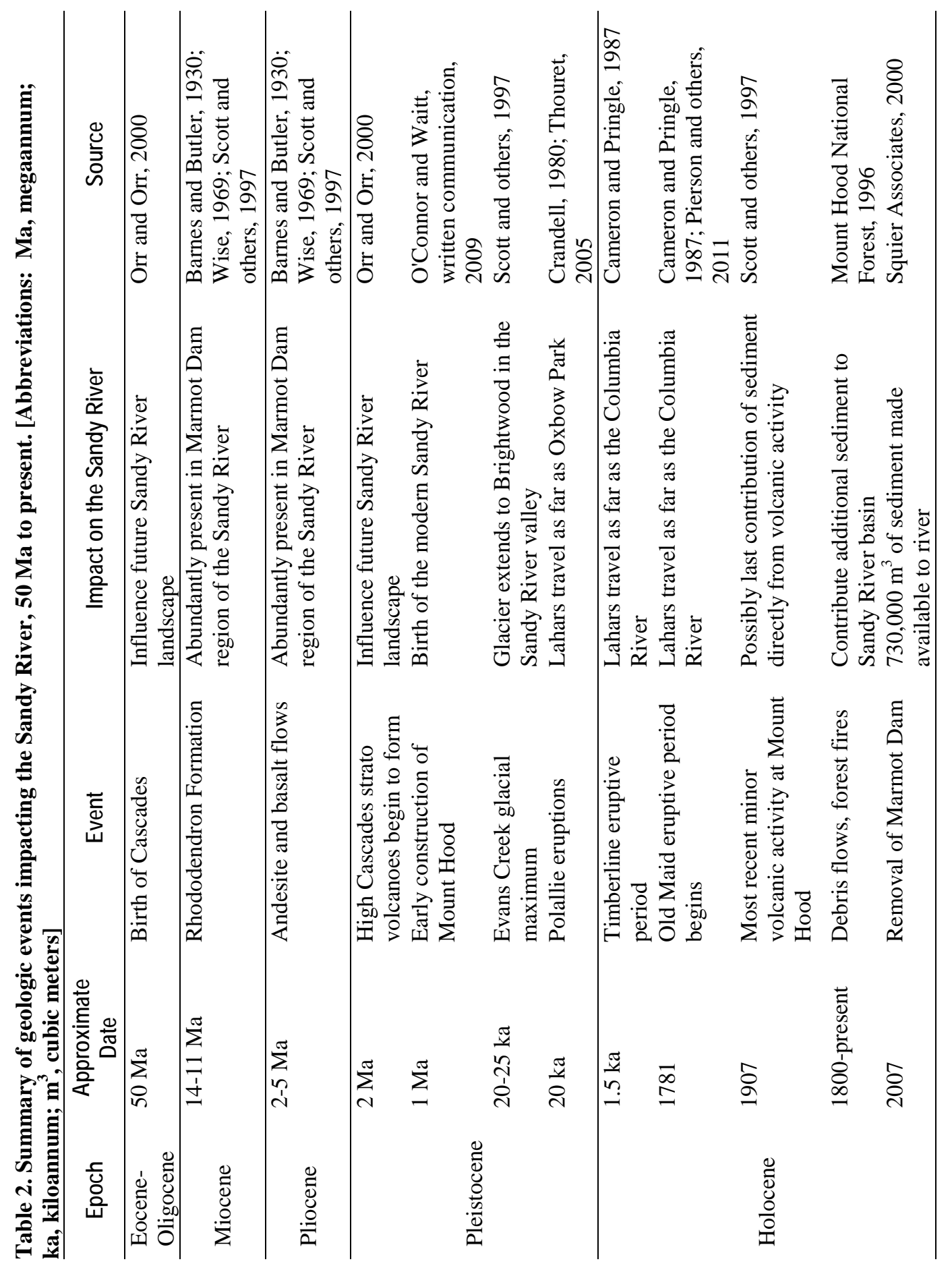


Three eruptive cycles at Mount Hood contributed abundant pyroclastic and laharic material to the Sandy River channel (Table 2). The Pollalie eruptions (15-22 ka), (Crandell, 1980; Thouret, 2005) produced pyroclastic flows and sent lahars as far downstream as the Columbia River. Similarly during the Timberline eruptive period (1.4-1.8 ka), sequences of pyroclastic flows and lahars entered the Sandy River and Zigzag River basins (Crandell, 1980; Cameron and Pringle, 1986). The most recent large-scale sedimentation event started in 1781, when the Old Maid eruptive episode produced lahars that again reached the Columbia River (Pierson and others, 2011). Terraces of Old Maid sand are preserved in the Beaver Island Reach between the former dam site and the Sandy River gorge (Figure 4), and reach a thickness of up to $15 \mathrm{~m}$ (Cameron and Pringle, 1987). Pierson and others (2009; 2011) describe the aggradation of the Timberline and Old Maid lahars as reaching $28 \mathrm{~m}$ and $23 \mathrm{~m}$ thick in the lower reaches of the Sandy River near Oxbow Park (Figure 2).

The Fraser glaciation (10-21 ka), specifically the Evans Creek stade (19-21 ka), is interspersed with the Pollalie volcanic activity at Mount Hood. However, the lowest moraine deposits found in the Sandy River valley are likely from an earlier glaciation, possibly during the same period as the [Mount Rainier] Hayden Creek Drift (0.14 Ma), which extended at least to the town of Brightwood (Crandell, 1980), about $13 \mathrm{~km}$ upstream of Marmot Dam. 


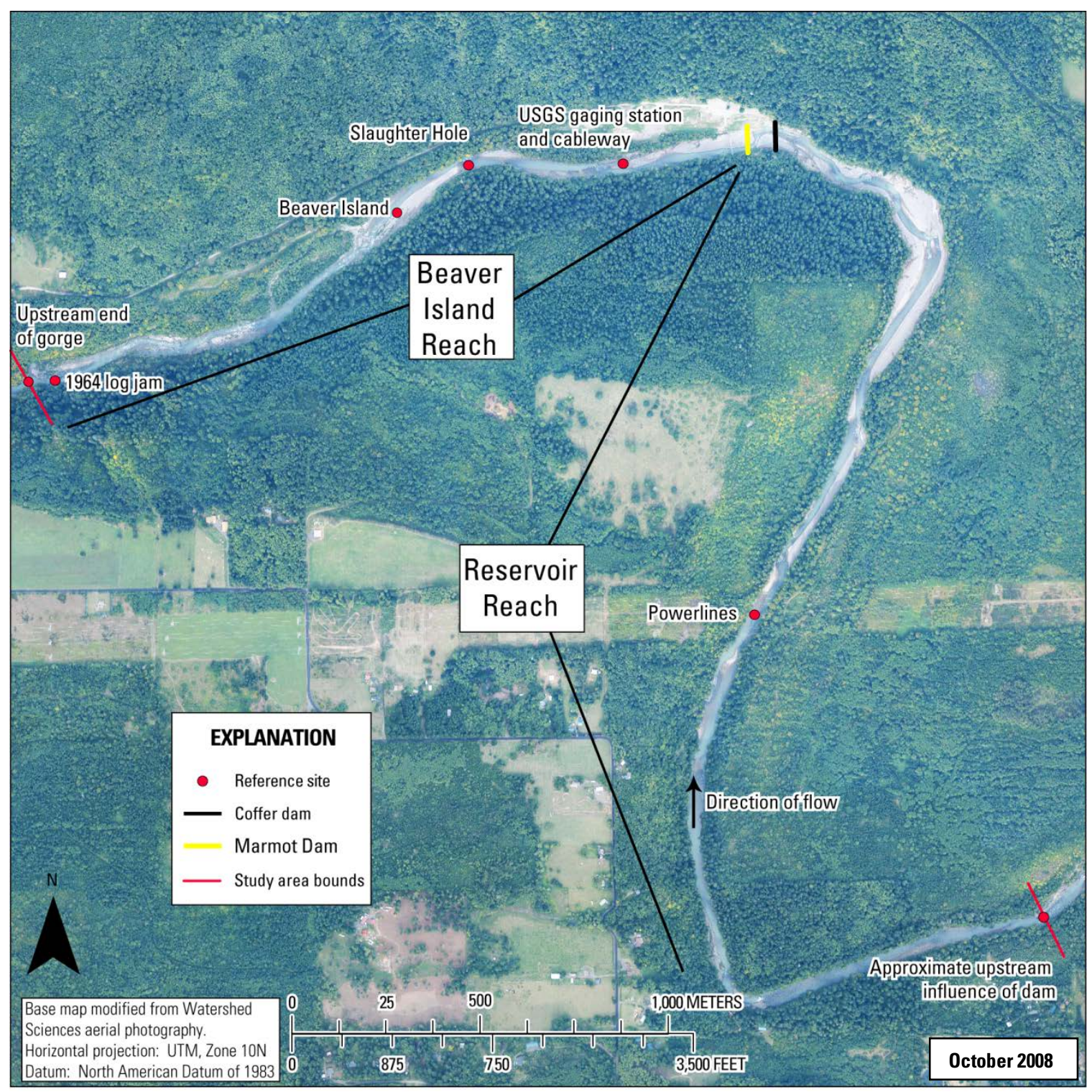

Figure 4. Aerial photograph of study area in the vicinity of Marmot Dam, Sandy River, Oregon. 


\section{Sedimentation in the Sandy River}

High sediment loads in the Sandy River are a legacy of extensive volcanism and glaciations at Mount Hood. Typical annual sediment yield at the Marmot Dam site is approximately $37,000-150,000 \mathrm{~m}^{3} /$ year, calculated by assuming the $750,000 \mathrm{~m}^{3}$ of sediment stored in the reservoir (Squier Associates, 2000) accumulated over a 5 to 20 year period (Stillwater Sciences, 2000a; FERC, 2003).

In addition to volcanism and glaciations, debris flows in the Sandy River corridor and its tributary drainages have contributed to the naturally high sediment load. Recent debris flows occurred in the Sandy River basin in 2000, 2003, and 2005 and in the Muddy Fork, a tributary to the Sandy River, in 2000 and 2002 (Pirot, 2009). Landslides are likely another source contributing to high sediment loads. Twenty-one percent of the upper Sandy River watershed has a high potential for landslides and 19 percent of the area has a moderate potential (Mount Hood National Forest, 1996). Furthermore, about 62 percent of the Salmon River watershed and 20 percent of the Zigzag River watersheds have a high potential for landslides (Mount Hood National Forest, 1996).

Additional sediment contributions during the late $19^{\text {th }}$ and early $20^{\text {th }}$ centuries may be derived from floods and debris flows following forest fires that destroyed vegetation in the upper watersheds. Estimates suggest nearly 75 percent of the upper Sandy River watershed was burned between 1873 and 1920 (Mount Hood National Forest, 1996). Extensive and unregulated logging throughout the basin in the late $19^{\text {th }}$ 
and early $20^{\text {th }}$ centuries, more restrictive logging in the mid to late $20^{\text {th }}$ century, and associated road building also have contributed sediment to the river (Taylor, 1998). Marmot Dam

Marmot Dam was located at river kilometer 48 on the Sandy River in Clackamas County, Oregon (Figure 2). An original timber crib diversion dam was completed in 1913 as part of the Bull Run Hydroelectric Project (Figure 5) and operated by the Portland Railroad, Light, and Power Company, which is now PGE. The dam was upgraded and replaced by a roller-compacted concrete structure 14.3-m-high with an Lshaped crest length of 105 m (about 60 m channel width) in 1989 (EBASCO, 1989; Esler, 2009). An estimated $750,000 \mathrm{~m}^{3}$ of gravel and sand filled the reservoir to nearly the top of the dam crest (Squier Associates, 2000). The extent of reservoir deposit was inferred as being approximately $3 \mathrm{~km}$ to $3.5 \mathrm{~km}$ upstream of the dam (Squier Associates, 2000); although, the extent of backwater effects are difficult to define. 


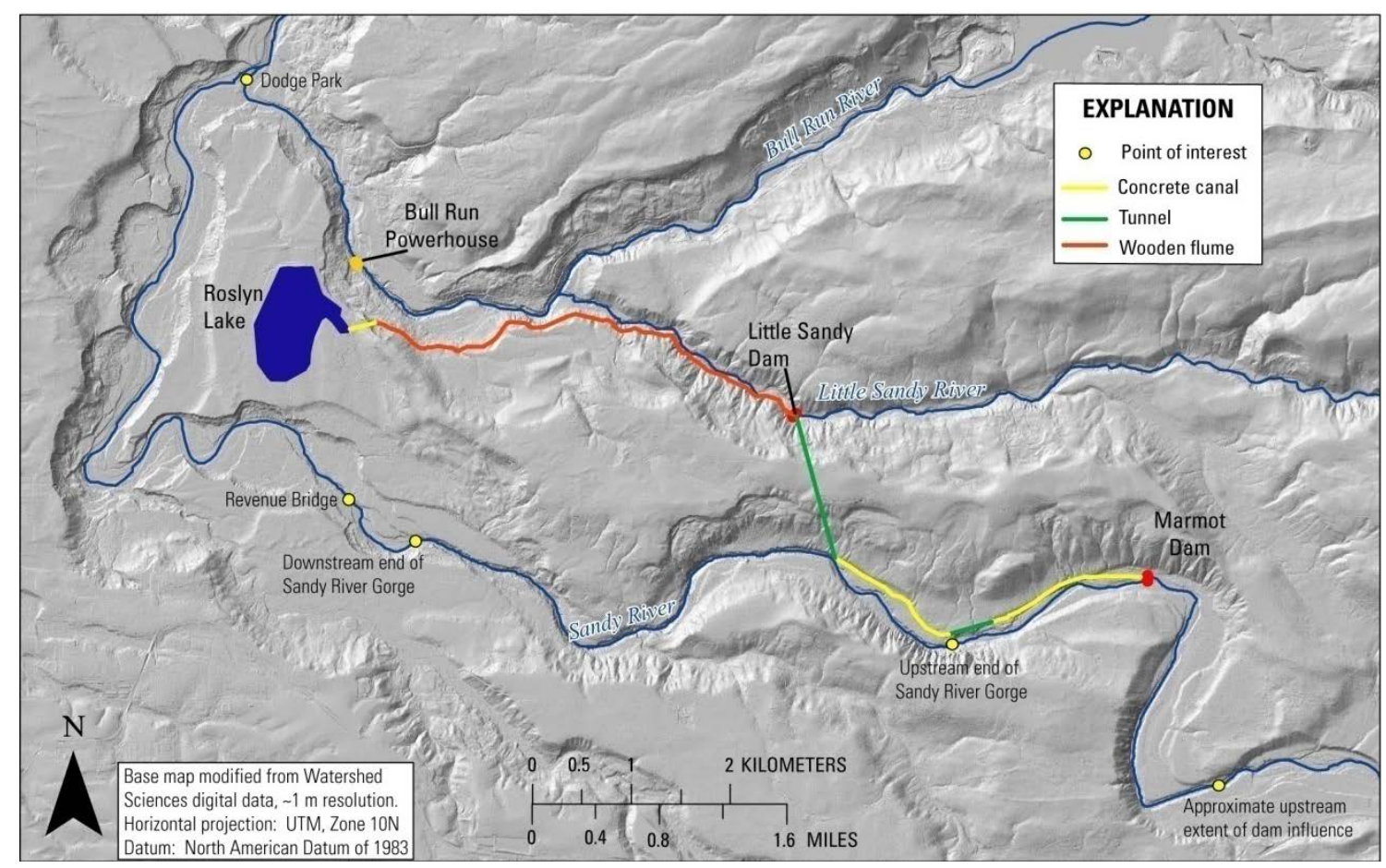

Figure 5. Major components of the Bull Run Hydroelectric Project operated by Portland General Electric. The project was decommissioned and Roslyn Lake was drained by 2008.

Study Reaches for the Sandy River

This project's focus is on the changes occurring within the $3.5 \mathrm{~km}$ Reservoir Reach upstream of the Marmot Dam and the Beaver Island Reach extending $2 \mathrm{~km}$ below the dam site (Table 3; Figure 4). Prior to the removal of Marmot Dam, the Reservoir Reach had a gradient of $0.0020 \mathrm{~m} / \mathrm{m}$ measured from LiDAR topography acquired in September 2007. Construction of the dam altered local base level of this reach, which is confined by steep, bedrock walls, and caused abundant sediment deposition. As a result, the reach changed from one that was steep and continual to one having alluvial morphology subject to backwater. Prior to dam removal, the long and narrow reservoir was bordered by intermittent bedrock outcrops and small local gravel bars in the upper 
parts. As the reservoir widened near the dam site, larger gravel bars formed. Average valley width in the Reservoir Reach is $40 \mathrm{~m}$. The sediment in the reservoir formed a wedge-shaped deposit assumed to pinch out approximately 3 to $3.5 \mathrm{~km}$ upstream of the dam (Squier Associates, 2000). Squier Associates (2000) detected two post-dam depositional units within the Reservoir Reach (Figure 6). Samples of an upper gravel unit (Unit 1, Figure 6) generally contained 0 to 10 percent sand and 60 to 90 percent gravel by weight. Samples of a sandy unit (Unit 2, Figure 6) generally contained less than 10 percent gravel but local lenses of more than 55 percent gravel were present. The composition of the sand (Unit 2) and gravel (Unit 1) units contained 0 to 23 percent and 30 to 45 percent gravel by weight, respectively. A basal layer, presumed to be the predam channel-bed (Unit 3, Figure 6) consisted of more than 50 percent gravel, cobbles, and boulders overlying a paleochannel deposit and bedrock (Figure 6). The total volume of the $750,000 \mathrm{~m}^{3}$ reservoir deposit was estimated to be approximately 2/3 gravel and 1/3 sand (Squier Associates, 2000), although uncertainty in the grain-size distribution of the impoundment could yield a distribution of approximately 1/2 gravel and 1/2 sand.

Table 3. Reservoir and Beaver Island reach conditions prior to the removal of Marmot Dam.

\begin{tabular}{|c|c|c|c|c|}
\hline Reach & $\begin{array}{c}\text { River } \\
\text { Kilometer }\end{array}$ & $\begin{array}{c}\text { Pre- } \\
\text { removal } \\
\text { Gradient }\end{array}$ & $\begin{array}{l}\text { Average } \\
\text { Floodplain } \\
\text { Width (m) }\end{array}$ & General Character \\
\hline $\begin{array}{l}\text { Reservoir } \\
\text { Reach }\end{array}$ & $\begin{array}{l}48 \text { to } \\
51.5\end{array}$ & 0.002 & 40 & $\begin{array}{l}\text { Long, narrow reservoir filled with sediment, few } \\
\text { small gravel bars in the upper } 2 \mathrm{~km} \text {, more expansive } \\
\text { bars present near the dam site, pool depth near the } \\
\text { dam site is roughly } 1 \mathrm{~m} \text { to } 1.5 \mathrm{~m} \text {, intermittent } \\
\text { bedrock outcrops }\end{array}$ \\
\hline $\begin{array}{l}\text { Beaver } \\
\text { Island } \\
\text { Reach }\end{array}$ & 46 to 48 & 0.008 & 85 & $\begin{array}{l}\text { Coarse bed with boulders present in channel, large } \\
\text { coarse bars present throughout, side channels } \\
\text { present }\end{array}$ \\
\hline
\end{tabular}




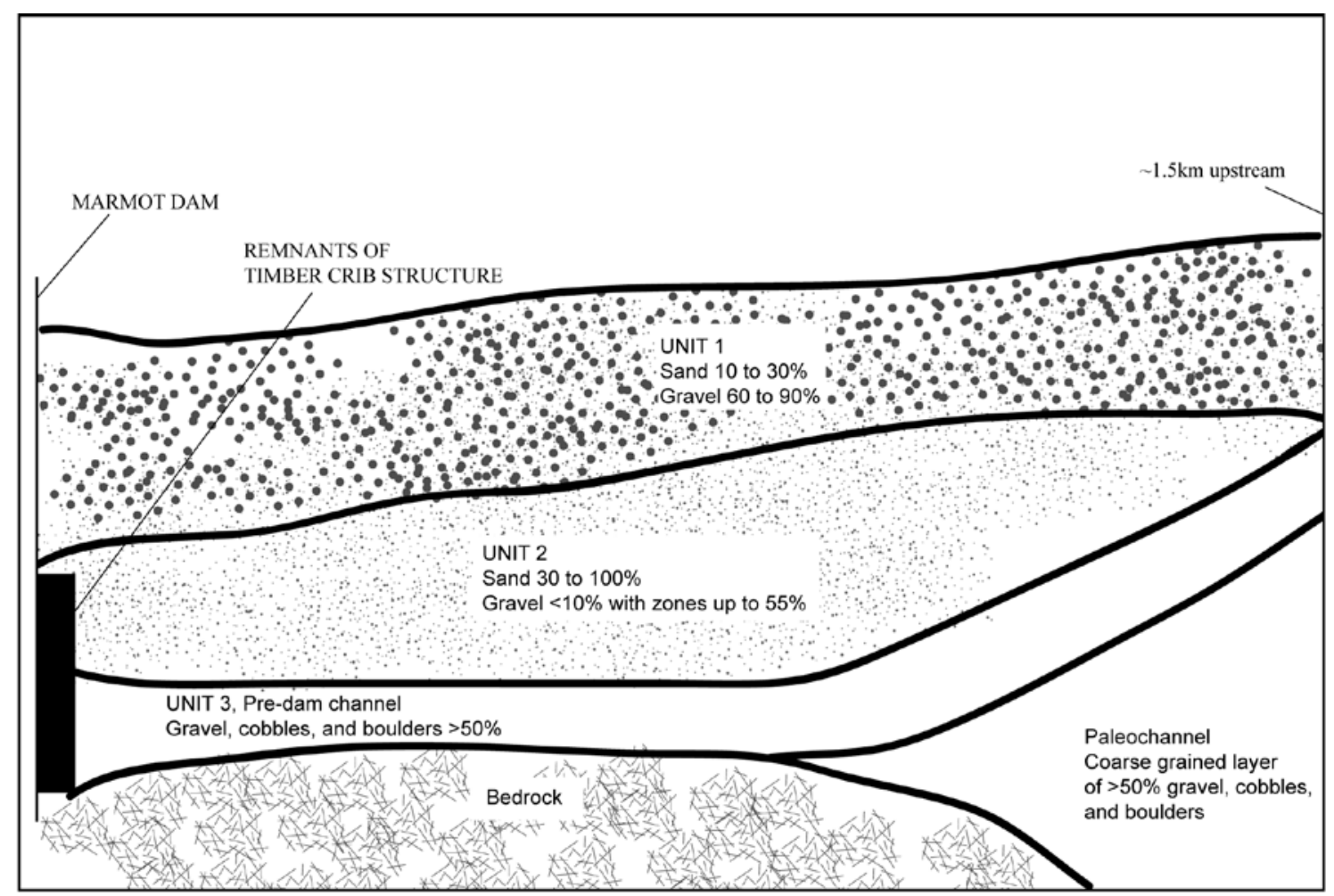

Figure 6. Schematic of the Marmot Dam reservoir deposit stratigraphy on the Sandy River, Oregon, extending about $1.5 \mathrm{~km}$ upstream of the dam site. Adapted from Squier Associates (2000). Not to scale.

The Beaver Island Reach, between the dam and the Sandy River gorge, traverses a relatively wider $(85 \mathrm{~m})$, alluvial reach for about $2 \mathrm{~km}$. This pool-riffle reach had a dam-era gradient of $0.006 \mathrm{~m} / \mathrm{m}$ (Table 3), and the river flowed over coarse gravel-toboulder sized bed material past a USGS streamflow-gaging station (14137000) before reaching a deep pool locally known as the slaughter hole (Figure 5). The channel then split around a sparsely vegetated, boulder bar known as Beaver Island. Downstream of Beaver Island, a larger, densely forested bar, bounded by a side channel fed mainly by 
seasonal hillslope runoff, occupies the right side of the valley. Just upstream of the entrance to the Sandy River gorge, a large log jam, likely created during the 1964 floods, obstructs most of channel. This log jam is aligned with another relatively large gravel bar bounded by an ephemeral channel on its right side (Figure 5).

Previous and on-going Marmot Dam studies

Pre-removal physical and chemical sediment analyses from borings, hand excavations, and test pits samples were examined to characterize grain size, reservoir stratigraphy, and impounded sediment volume (Squier Associates, 2000). Similar data were collected by EBASCO (1989) as part of their geotechnical investigations prior to dam upgrades in 1989. Stillwater Sciences (2000a, b) used reservoir-sediment composition data, channel gradient, and channel width to model sediment transport under different dam removal scenarios. They predicted that a 4-m-thick fan of sediment would deposit in the reach downstream of the dam within the first year, with continued, but decreasing, aggradation of up to $1 \mathrm{~m}$ over the subsequent decade.

Immediately following breaching of the coffer dam, erosion in the lower Reservoir Reach took place as a series of headcuts (Wallick and others, 2008). A 2-mhigh knickpoint developed at the coffer dam during the breach and quickly split into two separate knickpoints, one migrating directly upstream and a second migrating towards the right bank. While the location of the lateral knickpoint became fixed, erosion propagated rapidly upstream as the other knickpoint migrated through the unconsolidated sediment at 
rates as high as 480 to 4,800 m/day (Wallick and others, 2008, Major and others, in press).

Following dam removal, several private, governmental, and university personnel have conducted various analyses and contributed to research on the Sandy River's response to the removal. Data regarding channel morphology, sediment transport, and other variables contribute to the analysis included in this report. LiDAR topographic data, cross-section surveys commissioned by PGE through David Evans and Associates (DEA), pre- and post-removal topographic surveys by the U.S. Geological Survey, and time-lapse photography collected by the U.S. Geological Survey are the principal data used in this project. Appendix A summarizes post-removal monitoring and research efforts. 


\section{Chapter III: Pre-dam Channel Morphology}

Pre-dam reservoir basin topography was derived from a historical dam planning and construction map (PGE, 1911). The map consisted of contours with 1.5- to 3-meter contour intervals spanning a reach from $1,000 \mathrm{~m}$ upstream to $1,500 \mathrm{~m}$ downstream of the dam site and included generalized channel cross sections depicting bedrock walls and bed material. The contour map was converted to a digital elevation model by first mosaicking digital pieces of the original paper map (Figure 7). Eighteen control points were used to georeference the map utilizing a first order polynomial transformation in ArcGIS 9.3. These control points were derived from distinct topographic and near-channel bedrock outcrops on the 2006 LiDAR image. Additionally, the center and east and west quarter section locations for sec. 13, T. 2 S., R. 5 E. were labeled on the construction map. These locations were spatially referenced to the digital Public Land Survey System (PLSS) lines derived from U.S. Geological Survey digital line graphs and downloaded from the Oregon Geospatial Enterprise Office (2009). The pre-dam map was then rectified using the nearest neighbor resampling technique. I digitized the contours at a minimum scale of 1:500, from which surface interpolation was derived from a triangulated irregular network (TIN) surface creation in ArcGIS 9.3. 

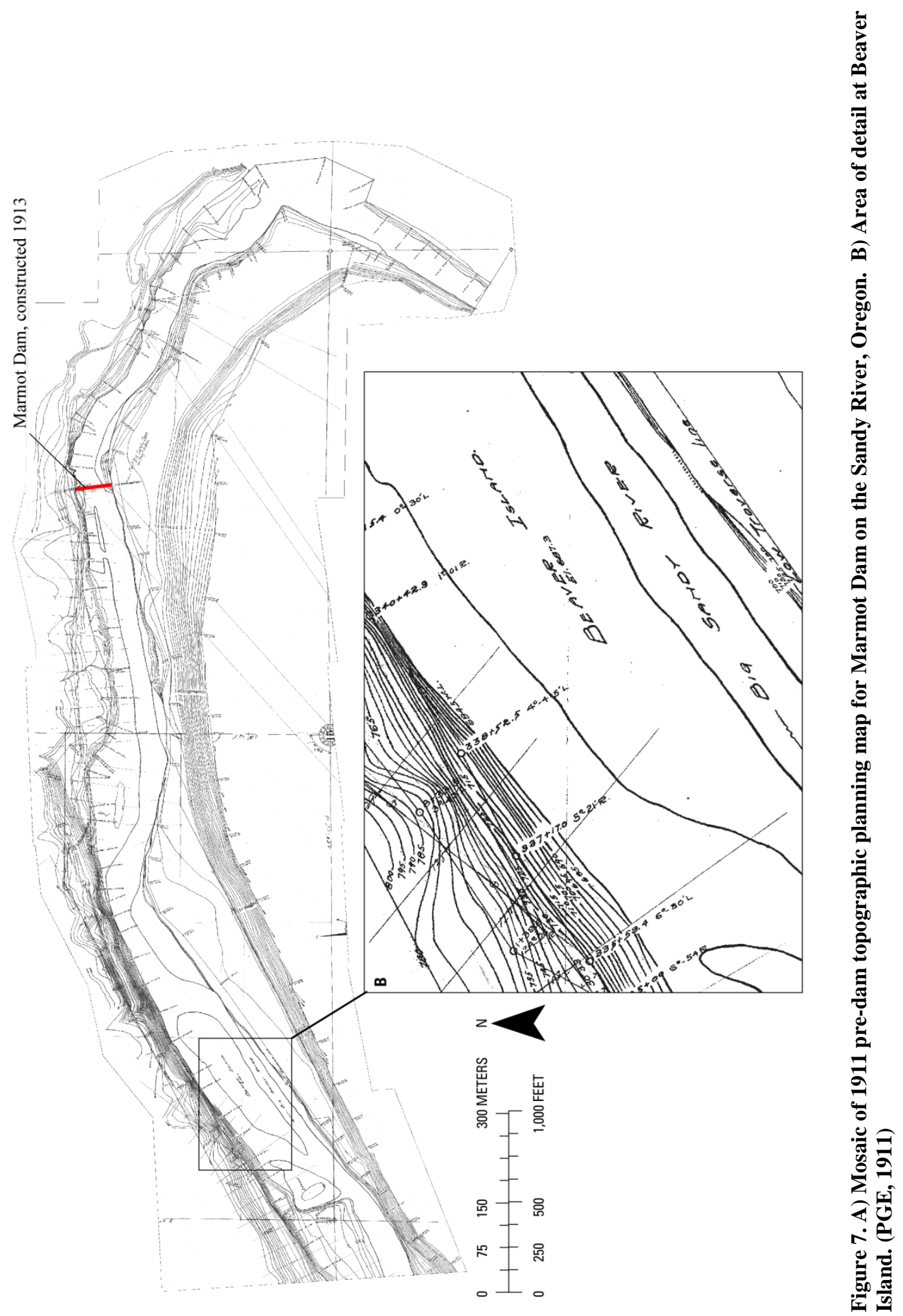
Channel elevations were extracted at 1-meter increments longitudinally along the channel centerline. Noise in the longitudinal profile extracted from the TIN surface, a consequence of the interpolation methods and variable contour data within the original map, was smoothed by 50-point moving average. Gradients for the upstream and downstream reaches were estimated through a linear fit to smoothed data point elevations. Cross-sectional data were also extracted at locations coinciding with more recent surveys, as discussed in Chapter IV.

Horizontal and vertical errors associated with the original topographic map are unknown, but are likely within the limits associated with georeferencing and interpolation error. The overall horizontal root mean square error obtained from control points used in georeferencing was $9.6 \mathrm{~m}$; therefore $10 \mathrm{~m}$ is considered to be the approximate horizontal error. The maximum error of 15.4 m occurred near the map boundary, away from the area of interest and where the control points were concentrated near the channel. Vertical errors measured between the 1911 surface and LiDAR topography are typically less than $3 \mathrm{~m}$ near the channel and increase towards the edges of the pre-dam surface. No vertical datum was provided on the 1911 map, so no adjustment of the map to North American Vertical Datum of 1988 (NAVD 88) was made during processing. Differences between early mean sea level datum and the National Geodetic Vertical Datum of 1929 (NGDV 29) are about $0.15 \mathrm{~m}$, whereas those between NGVD 29 and NAVD 88 can range up to $2.2 \mathrm{~m}$ (NOAA, 2010). It is likely that the difference between the 1911 surface and NAVD 88 is within $1.5 \mathrm{~m}$ and $2.0 \mathrm{~m}$, a magnitude typical of the western United States 
(Zilkoski and others, 1992). Estimated vertical error likely lies within this range. Therefore, a constant $2.0 \mathrm{~m}$ was subtracted from the systematically high pre-dam longitudinal profile values to best approximate a NAVD 88 vertical datum.

General Land Office (GLO) cadastral surveys completed in the late $19^{\text {th }}$ and early $20^{\text {th }}$ century, downloaded from the Bureau of Land Management (BLM, 2009), provide additional context for the early character of the Sandy River before and soon after the construction of Marmot Dam. GLO surveys completed in May 1860 in the downstream $\sim 1 \mathrm{~km}$ of the reservoir were used to qualitatively assess the pre-dam nature of the Sandy River (Burnett, 1860). Notes from a 1918 GLO resurvey (Rodolf, 1918), USGS profile surveys completed in 1913 (USGS, 1914), and Squier Associates (2000) reservoir stratigraphy were used to estimate upstream channel change in the early years following construction of Marmot Dam.

The 1911 pre-dam cross sections depict the Sandy River flowing over boulders and other coarse material between bedrock canyon walls in the lower part of the Reservoir Reach. The overall planform of the pre-dam Sandy River (Figure 8) is similar to that of its dam-era and post-dam form largely because channel location is controlled by valley topography and bedrock outcrops. Expectedly, features such as Beaver Island and gravel bars in the lower Reservoir Reach closely resemble of what the 1911 map displays (Figure 7).

Channel gradient varies within reaches according to local topography. Pre-dam longitudinal profiles (Figure 8, Figure 9) yield a Reservoir Reach gradient of $0.006 \mathrm{~m} / \mathrm{m}$ 


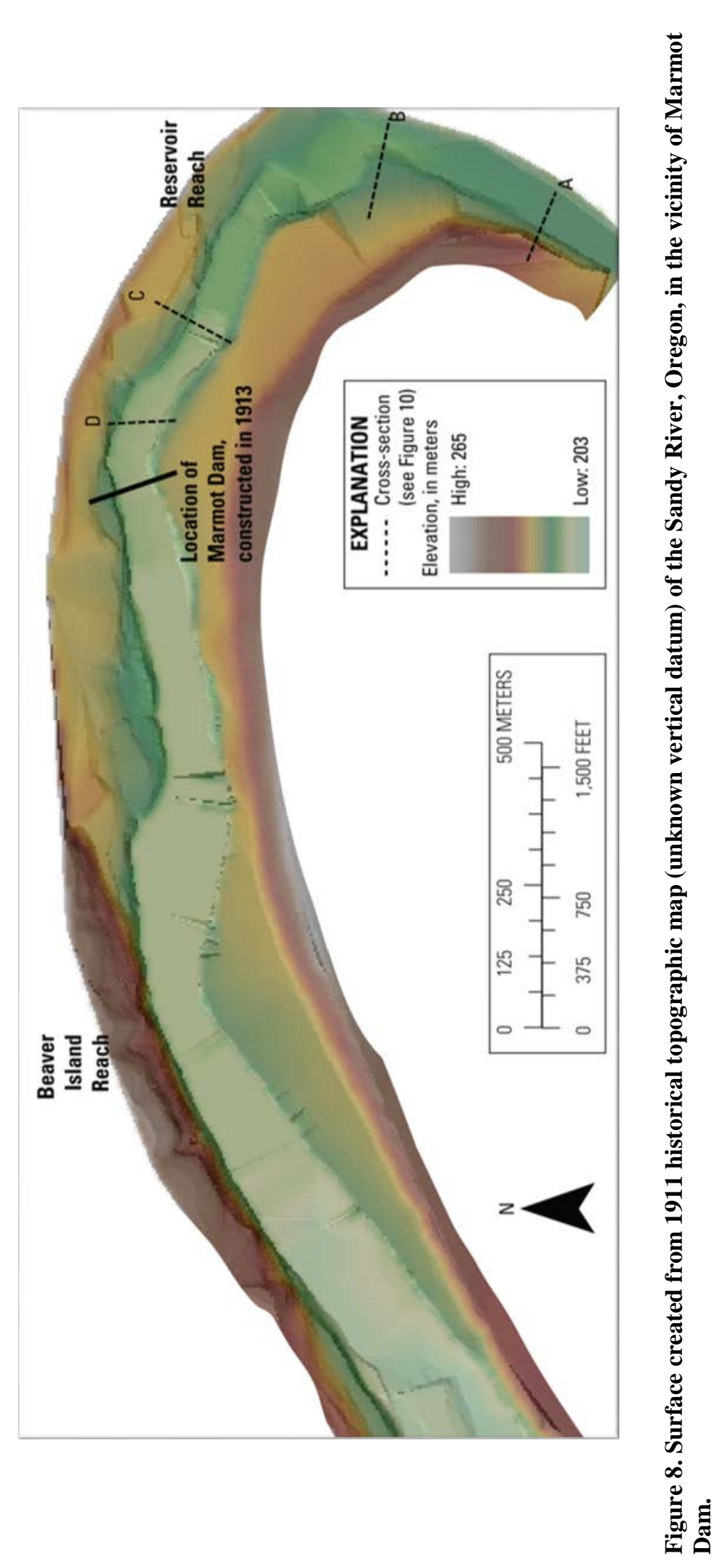


in the first kilometer upstream. The average pre-dam channel gradient in the Beaver Island Reach, from the dam site to $1.5 \mathrm{~km}$ downstream, was 0.004 to $0.005 \mathrm{~m} / \mathrm{m}$.

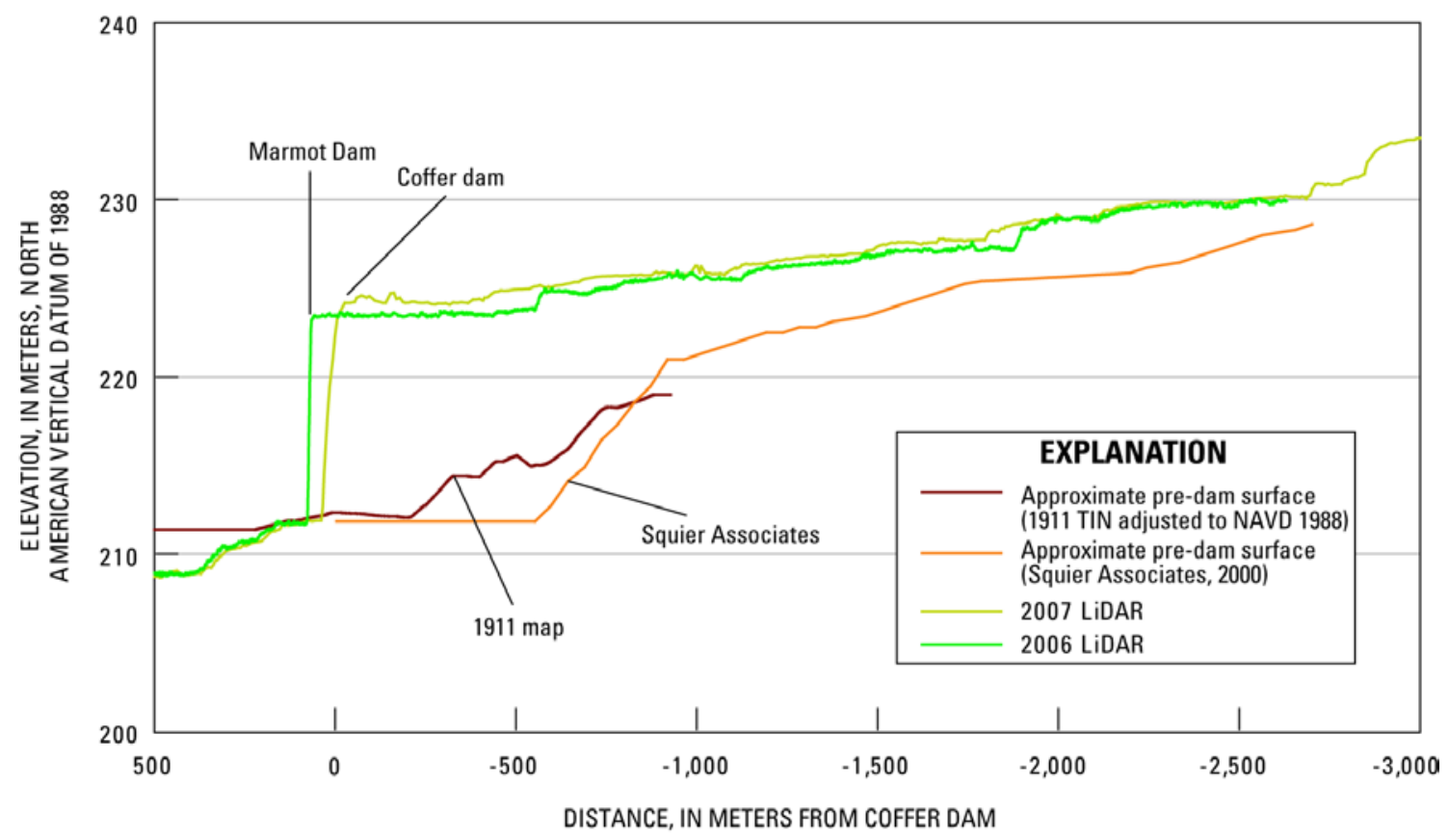

Figure 9. Longitudinal profiles extracted from 1911 interpolated TIN surface, the top of Squier Associates' (2000) Unit 3 (pre-dam bed surface), and the 2007 and 2008 LiDAR digital elevation models of the Sandy River reservoir area.

Discrepancies between the 1911 pre-dam profile and the Squier Associates (2000) pre-dam bed-surface profile (Figure 9) may be due to sparse data collection of Squier Associates within the Reservoir Reach. An anomalously flat stretch directly downstream of the dam site, and extending $0.8 \mathrm{~km}$ through the upstream end of the Beaver Island Reach, may be due to limited historical topographic information.

Cross sections through the Reservoir Reach (Figure 10A-D) indicate pre-dam channel widths may have approached $60 \mathrm{~m}$ (Figure 10A), although the channel through 
most of the Reservoir Reach typically ranged between 40 and 50 m wide. The pre-dam channel width and location are similar to that imaged by the 2008 LiDAR. Differences in cross-sectional form in 1911 and those profiled in 2010 after dam breaching show how the eroded reservoir deposit is approaching geometry similar to that of the pre-dam channel.
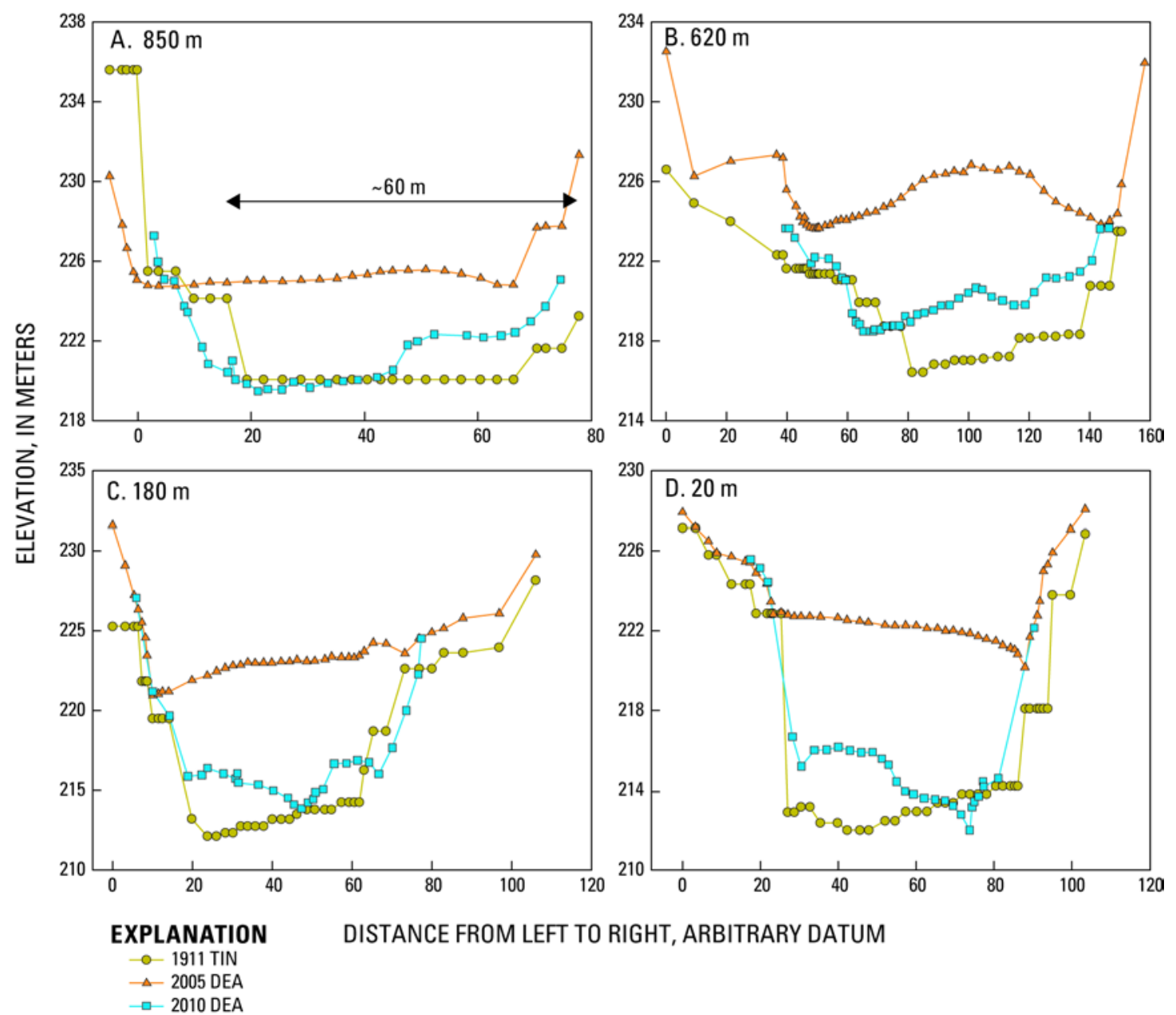

Figure 10. Comparison of 1911 pre-dam surface cross-sections with those of pre- and post-removal cross sections within the reservoir surveyed by David Evans and Associates. Locations at A) $850 \mathrm{~m}$, B) $620 \mathrm{~m}$, C) $180 \mathrm{~m}$, and D) $20 \mathrm{~m}$ upstream of the coffer dam location. 
Burnett’s (1860) historical survey notes from a General Land Office (GLO) cadastral survey upstream of the dam location describe the Sandy River as "Right bank of Sandy River deep, rapid current, stoney bed....” The description is similar to that which one would see today from that location as the water is channeled around a bedrock controlled bend (Figure 11).
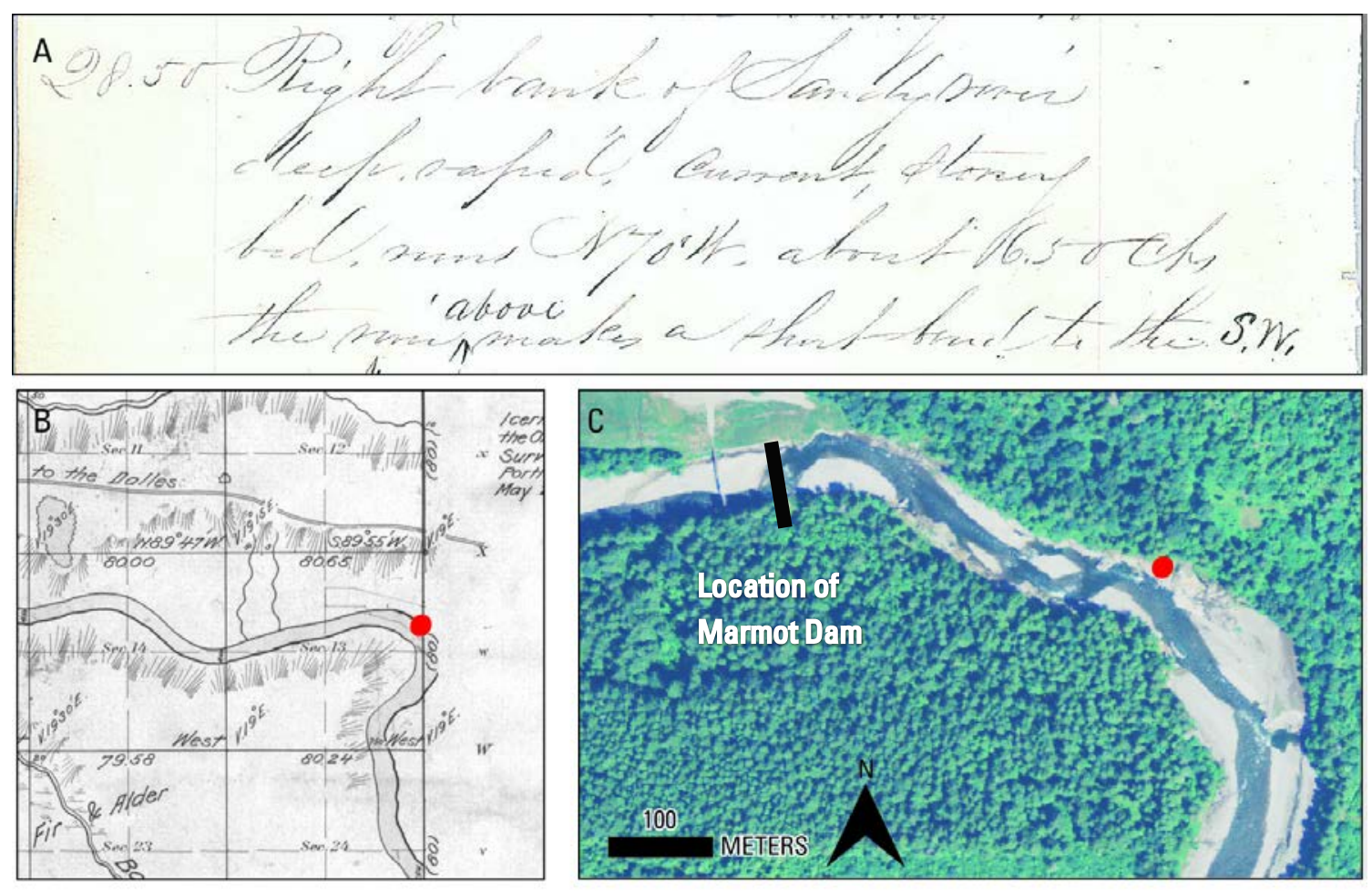

Figure 11. Notes (A) and map (B) from a General Land Office survey conducted in 1860 and (C) a 2009 aerial photograph with red dot denoting the location referred to in the notes.

Surveys completed prior to and after the construction of Marmot Dam describe a transformation in the landscape. In 1860 Burnett claimed, “..the place for $1 / 4$ sec [corner] will be in the river.” Prior to dam construction, the Sandy River in the study reach was a high-energy, gravel-bed stream flowing through reaches of incised bedrock and slightly 
wider alluvial sections. The GLO resurvey of the east boundary of T. 2 S., R. 5 W. was completed in 1918, about four years after Marmot Dam’s construction. Within a few years of damming, the Reservoir Reach had shallowed in gradient and aggraded sufficiently to change the channel conditions at the true west $1 / 4$ section corner from being in the river to land subject to overflow suggesting a typically high sediment yield for the Sandy River. Rodolf (1918) describes the, “True point for $1 / 4$ sec. [corner] falls on land subject to overflow,” indicating that the channel had filled with sediment at that location.

In the years following completion of Marmot Dam, Reservoir Reach surveys depict how much the channel had responded to the dam's presence. Profile surveys completed by the USGS (1914) in 1913 document a water-surface gradient of 0.0014 m/m between $800 \mathrm{~m}$ and 2,200 m above Marmot Dam, a roughly 75 percent decrease in gradient compared to pre-dam conditions. This water-surface profile is probably not a good proxy for the channel-bed profile because it is unlikely the reach had filled with sediment in the first year following dam completion. The 1913 water-surface gradient is similar to gradients measured in 2007 prior to dam removal, $0.002 \mathrm{~m} / \mathrm{m}$, extending 3,200 m upstream of the dam site. 


\section{Chapter IV: Post-dam Vertical and Horizontal Changes in Channel Morphology}

Changes in channel form were measured in various ways for two time frames: 1) by time-lapse photography for rapid initial change (19 October to 5 November 2007) in the lower $\sim 100 \mathrm{~m}$ of the Reservoir Reach and 2) by channel and LiDAR surveys for longer term change (5 November 2007 to September 2009).

Methods to measure channel changes during and immediately following breaching

Oblique time-lapse terrestrial photography at 10 to 30 minute intervals was

recorded by five Canon EOS Rebel XTi digital SLR cameras surrounding the lower 430 $\mathrm{m}$ of the reservoir. The photographs captured changes within the lower $100 \mathrm{~m}$ of the reach (Major and others 2010b; Figure 12). Photographs on 19 October 2007, taken during breaching with a Nikon D80 camera supplemented photographic documentation. Photographs taken at ten minute intervals were processed beginning at 1700 PDT through 1840 PDT, 19 October 2007, and again between 0710 PDT through 0900 PDT, 20 October. The processing interval was reduced to thirty minutes starting 0900 PDT, 20 October until 1200 PDT, 21 October after which it was reduced to one hour intervals until 1800 PDT, 24 October and finally to once a day until 5 November 2007. Imagery obtained at night, between 1850 PDT and 0700 PDT, was often too dark to be used. 


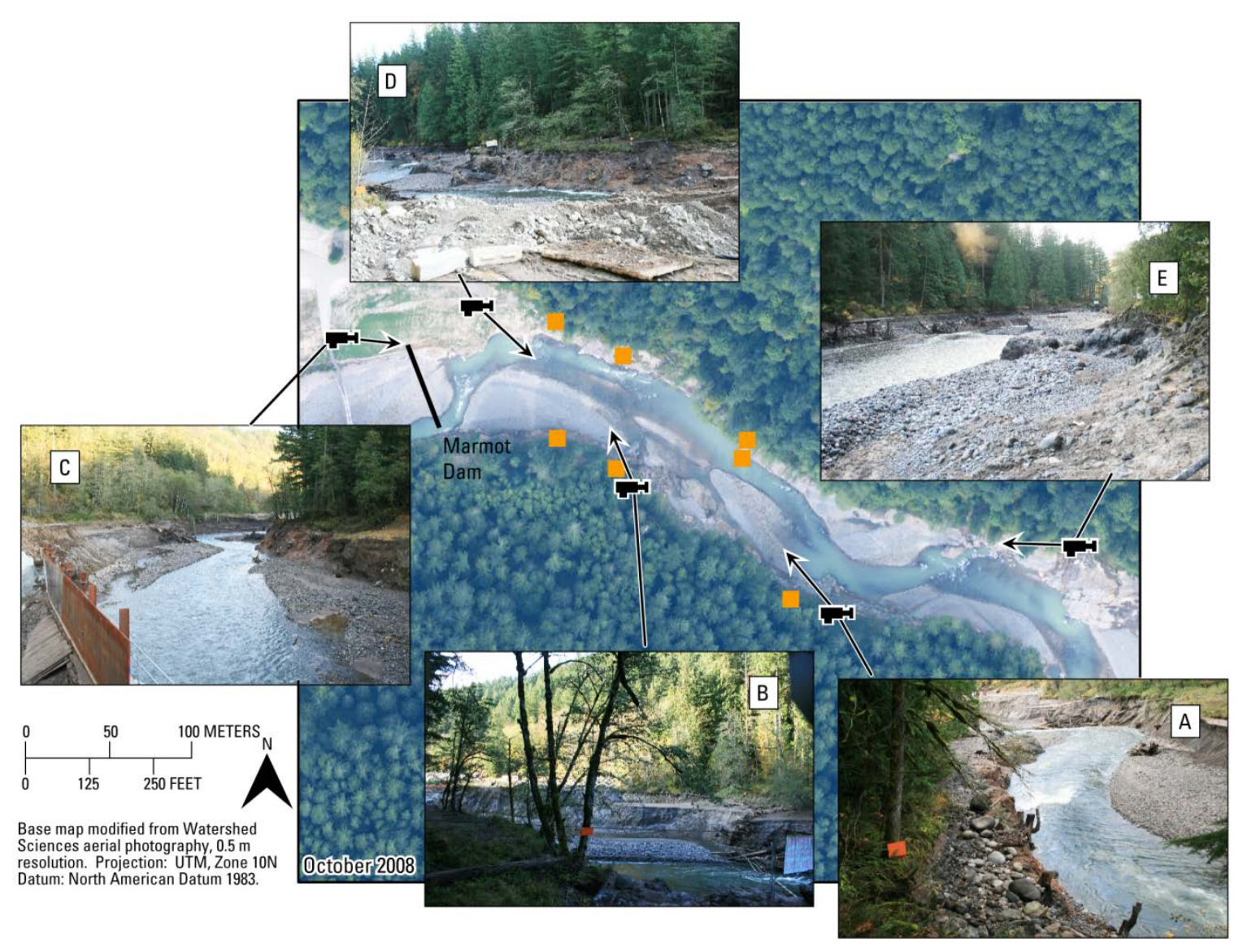

Figure 12. Locations of camera stations and points of view from these locations. Orange targets visible in photographs were used to provide control in PhotoModeler processing. Arrows indicate direction of camera view. A) Camera 1, view downstream from left bank in reservoir, B) Camera 2, view downstream from left bank in reservoir with dam-hazard sign visible in lower right-hand corner of photograph, C) Camera 3, view upstream near pedestrian bridge below the dam site, D) Camera 5, view upstream from right bank in reservoir with dam-hazard sign visible near center of photograph, and E) Camera 4, view downstream from right bank in reservoir.

PhotoModeler 5.2 photogrammetric software was used to quantify temporal changes in elevation and width of the Sandy River. PhotoModeler uses collinear equations to compute the intersection of light rays for three-dimensional points to calculate the position and angle of each camera, and a spatial model is constructed from this information. The model is based on vectors which are tied to the camera location 
(EOS, 2004). Spatial controls on imagery were provided by camera calibration and ground control points within the field of view. Camera calibrations define the focal length, lens distortion, format aspect ratio, and principal point for each camera and were computed within the PhotoModeler software to provide internal control for the models. Ground control points were fixed, orange targets measuring about $35 x 50 \mathrm{~cm}$. A preexisting dam-hazard sign of known location was also used as a control (Figure 12). Figure 13 illustrates how rays from cameras 2 and 5 intersect the orange photograph targets present in multiple photographs. Coordinates of the photograph targets were initially collected with a total station tied to a base station located by GPS and provide a constraint on modeled spatial data.

The control points were used to spatially register each photograph within the PhotoModeler software. Three to five photographs with overlapping, but not stereoscopic, imagery were chosen for each time interval (Table B1) on the basis of photograph clarity and identifiable control points in multiple images. A minimum of six tie points between each set of photographs were assigned to match photographs. Tie points could consist of any object visible in multiple photographs. Tie points are important in construction of the three-dimensional model and are best utilized by the software when distributed across photographs with about 60 percent overlap, although, some of the photograph sets used had less overlap. In some instances, weather obscured the control and tie points and thus, other identifiable features were used to register the photographs, such as bedrock outcrops, stumps, and construction equipment. 


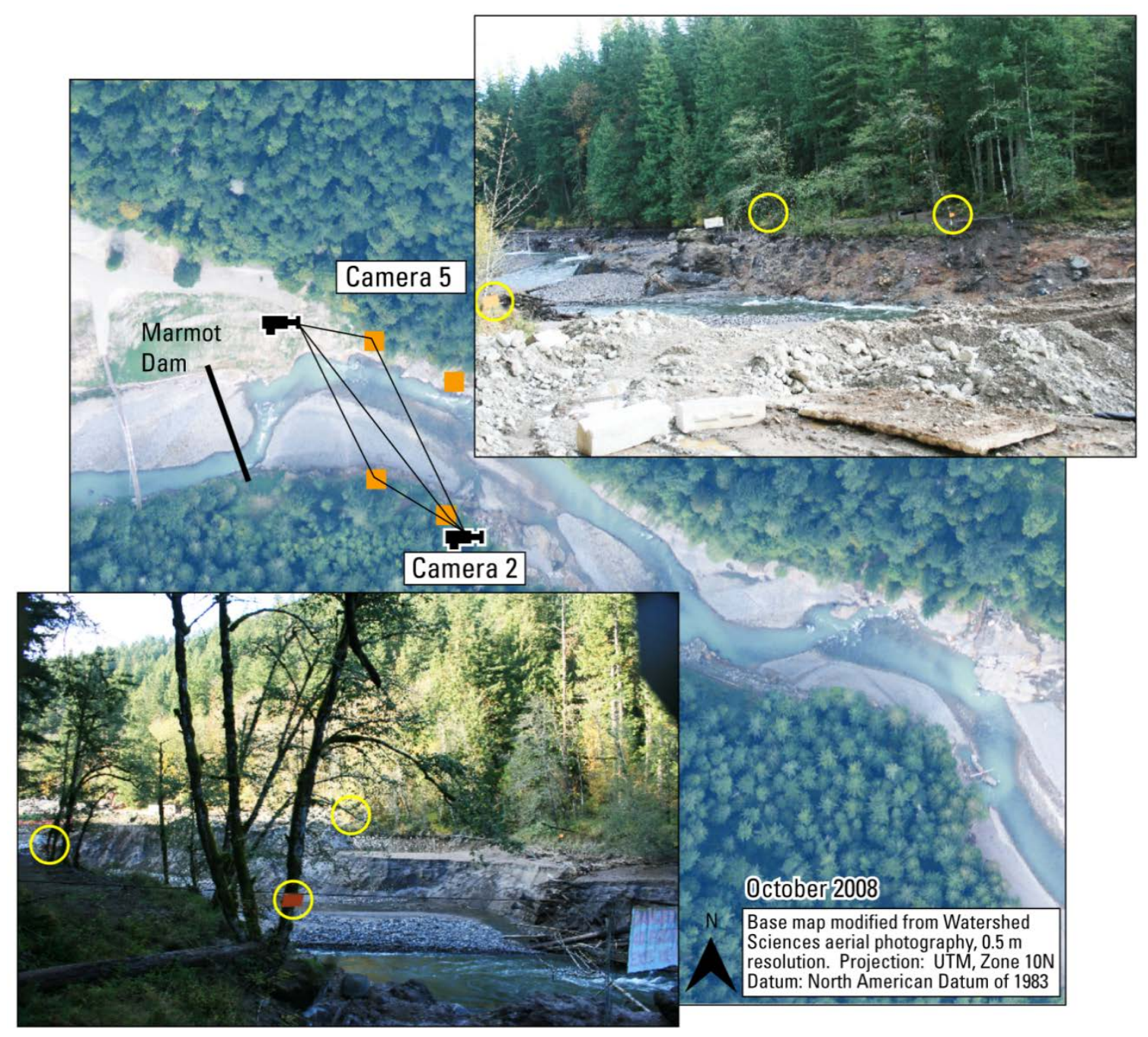

Figure 13. PhotoModeler creates a model based on coincident points between photographs. This example shows where rays from cameras 2 and 5 would intersect the orange photograph targets. Yellow circles indicate the location of targets within the terrestrial photographs.

Once photographs are registered, additional common points are marked to better identify spatial coordinates within the zones of channel modification to measure changes in water surface elevation and channel width. The spatial data were exported from PhotoModeler to ArcGIS 9.2/9.3 for measurement. The standard measuring tool in 
ArcGIS was used to measure reservoir elevation and width changes between photograph processing intervals. Channel measurements were recorded at $56 \mathrm{~m}$ downstream of the coffer dam crest, near the base of the coffer dam, and at $8 \mathrm{~m}, 43 \mathrm{~m}$, and $81 \mathrm{~m}$ upstream of the coffer dam crest. These locations were chosen for making repeat measurements because of the proximity to stationary objects, such as tree stumps or bedrock knobs which helped identify those locations as the river landscape evolved.

The accuracy of the photogrammetric model depends on the quality of the camera calibration, ground control points, and photographs, photograph overlap, point marking accuracy, placement of points, and number of common points tagged. The accuracy of the camera calibration likely introduces smaller errors than the accuracy of the ground control points and error introduced by mismatched points (Major and others, 2009).

Errors associated with PhotoModeler processing are reported as error in processing and as a point marking residuals (in pixels). The PhotoModeler user manual recommends the total error be less than 1 (unitless value) and the root mean square of residual error to be less than 5 pixels (EOS, 2004). Models with errors greater than these values likely have poor point matching or constraint quality. However, these values are difficult to attain when modeling complex surfaces in dynamic landscapes as few tie points between photographs are stable among photographs. Therefore, an arbitrary upper limit of 10 for total error value and 10 pixels for overall root mean square error point marking residual were used in photograph analysis. Several other measures of quality assessment, such as point tightness and precision which are estimates of the offset of 
point placement expected by the model, are also provided as part of the processing report; however, these were generally ignored because the total and residual error appeared to provide the meaningful measures of model accuracy. To assess accuracy, coordinates of stable points such as bedrock knobs were compared among models; these generally varied by less than about $0.6 \mathrm{~m}$. For example, at one location repeatedly measured between 26 October and 5 November, the maximum difference in elevation was $0.27 \mathrm{~m}$ while the average was less than $0.01 \mathrm{~m}$.

Eighty-nine models were produced in PhotoModeler at time steps ranging from 10 minutes to 1 day over the first two weeks following dam breach. Typically, a model was processed using three photographs and had an average total error of \pm 5.46 and average overall RMS point marking residual of \pm 5.54 pixels. All models had total error and overall RMS values less than 10 (Table B1). The errors associated with models generated from photograph analysis early in the time sequence likely stem chiefly from the operator error owing to challenges matching reference points under rapidly changing conditions. Furthermore, reference points in one model may have been eroded and are absent in a consecutive model. The error associated with models after 25 October changed when two cameras were relocated farther upstream, due to the reduced number of ground control points within the photographs and the decreased overlap among all photographs. 
Methods to measure channel changes 2 weeks to 2 years following dam removal

Eight ground-based topographic surveys of the river channel (Table 4) conducted after dam removal allowed for more expansive spatial and temporal monitoring compared to the photographic analyses. The surveys began 2.5 weeks after breaching and continued episodically for two years. The objective of the surveys was to capture channel changes associated with erosion and deposition following high-flow events (Figure 14). Bar features, bases and tops of banks, edges of water, and local cross sections were surveyed using a WILD Heerbrugg TC1000 total station. ASCII output was processed in Excel to convert distances and angles to three-dimensional spatial coordinates that were imported into ArcGIS 9.2/9.3 for analysis.

Changes in channel width were documented at cross sections spaced $250 \mathrm{~m}$ apart through the Reservoir Reach. The width was measured from the left to right bank, defined in field notes as 'top of cut bank'. Where no survey data were available for a particular site, locations from the previous survey were used, and positions were assumed to be unchanged. A minimum average rate of widening was calculated between the starting dates of the respective surveys. Actual widening rates are likely greater than average values because channel widening likely occurred episodically at high discharges and not constantly over the time between surveys.

Longitudinal profiles of water-surface elevation, measured along the edge of the channel, are assumed to approximate the profile of the channel thalweg. Linear fits to the 
Table 4. Summary of data used to detect changes upstream of the former Marmot Dam on the Sandy River, Oregon, including sources, collection dates, scales, and mean daily discharges at collection dates. [Abbreviations: $\mathrm{m}^{3} / \mathrm{s}$, cubic meters per second; LiDAR, Light Detection and Ranging; WS, Watershed Sciences and refers to reports by Watershed Sciences (2006, 2008, 2009); DEA, David Evans and Associates and refers to reports by DEA (2005, 2006, 2007, 2008, 2009); USGS, U.S. Geological Survey; NAIP, National Agricultural Imagery Program; m, meter; -, no data or unknown]

\begin{tabular}{|c|c|c|c|c|}
\hline Item & Source & Collection Date & $\begin{array}{l}\text { Original } \\
\text { Scale }\end{array}$ & $\begin{array}{c}\text { Mean Daily } \\
\text { Discharge, } \mathrm{m}^{3} / \mathrm{s}\end{array}$ \\
\hline 2006 LiDAR & WS & Oct. 22, 2006 & $\begin{array}{l}1 \mathrm{~m}=1 \\
\text { pixel }\end{array}$ & 8.8 \\
\hline 2007 LiDAR & WS & $\begin{array}{l}\text { Sept. 29-Oct. 7, } \\
2007\end{array}$ & $\begin{array}{l}1 \mathrm{~m}=1 \\
\text { pixel }\end{array}$ & $13.3-28.6$ \\
\hline 2008 LiDAR & WS & $\begin{array}{l}\text { Sept. 29-Oct. 1, } \\
2008\end{array}$ & $\begin{array}{l}1 \mathrm{~m}=1 \\
\text { pixel }\end{array}$ & $11.9-12.2$ \\
\hline 2005 cross-section survey & DEA & - & - & - \\
\hline 2006 cross-section survey & DEA & - & - & - \\
\hline 2007 cross-section survey & DEA & - & - & - \\
\hline 2008 cross-section survey & DEA & Sept. 2008 & - & - \\
\hline 2009 cross-section survey & DEA & Sept. 2009 & - & - \\
\hline $\begin{array}{l}\text { November 2007a topographic } \\
\text { survey }\end{array}$ & USGS & Nov. 5-7, 2007 & - & $11.1-11.4$ \\
\hline $\begin{array}{l}\text { November 2007b topographic } \\
\text { survey }\end{array}$ & USGS & Nov. 23, 2007 & - & 29.7 \\
\hline $\begin{array}{l}\text { December } 2007 \text { topographic } \\
\text { survey }\end{array}$ & USGS & Dec 11-12, 2007 & - & 31.4-34.5 \\
\hline January 2008 topographic survey & USGS & $\begin{array}{l}\text { Jan. 16, 18,13 24, } \\
2008\end{array}$ & - & $27.0-57.2$ \\
\hline May 2008 topographic survey & USGS & May 7-9, 2008 & - & $63.9-81.0$ \\
\hline $\begin{array}{l}\text { September } 2008 \text { topographic } \\
\text { survey }\end{array}$ & USGS & $\begin{array}{l}\text { Sept. 10-12, 16-18, } \\
2008\end{array}$ & - & $12.8-13.8$ \\
\hline January 2009 topographic survey & USGS & $\begin{array}{l}\text { Jan. 21-23, 30, } \\
2009\end{array}$ & - & 31.1-43.6 \\
\hline $\begin{array}{l}\text { September } 2009 \text { topographic } \\
\text { survey }\end{array}$ & USGS & $\begin{array}{l}\text { Sept. 8-11, 15, } \\
2009\end{array}$ & - & $8.2-9.5$ \\
\hline 2005 aerial photography & NAIP & July 20, 2005 & $\begin{array}{l}1 \mathrm{~m}=1 \\
\text { pixel }\end{array}$ & 12.4 \\
\hline 2008 aerial photography & WS & Oct. 1, 2008 & $\begin{array}{l}1 \mathrm{~m}=0.5 \\
\text { pixel }\end{array}$ & 12.0 \\
\hline 2009 aerial photography & NAIP & June 23-24, 2009 & $\begin{array}{l}1 \mathrm{~m}=1 \\
\text { pixel }\end{array}$ & $26.8-27.4$ \\
\hline 2007 time-lapse photography & USGS & $\begin{array}{l}\text { Sept. 2007-May } \\
2008\end{array}$ & - & 23.3-62.3* \\
\hline 1860 GLO survey & BLM & $\begin{array}{l}\text { May 23-June 4, } \\
1860\end{array}$ & $1: 31,680$ & - \\
\hline 1918 GLO survey & BLM & Apr. 3-11, 1918 & $1: 31,680$ & $36.0-51.5$ \\
\hline 1911 Topographic survey & PGE & 1911 & - & - \\
\hline 1914 Plan and profile survey & USGS & 1913 & $1: 31,680$ & - \\
\hline
\end{tabular}

*Mean daily discharge for photographs used in this study, 19 through 25 October, 2007. 


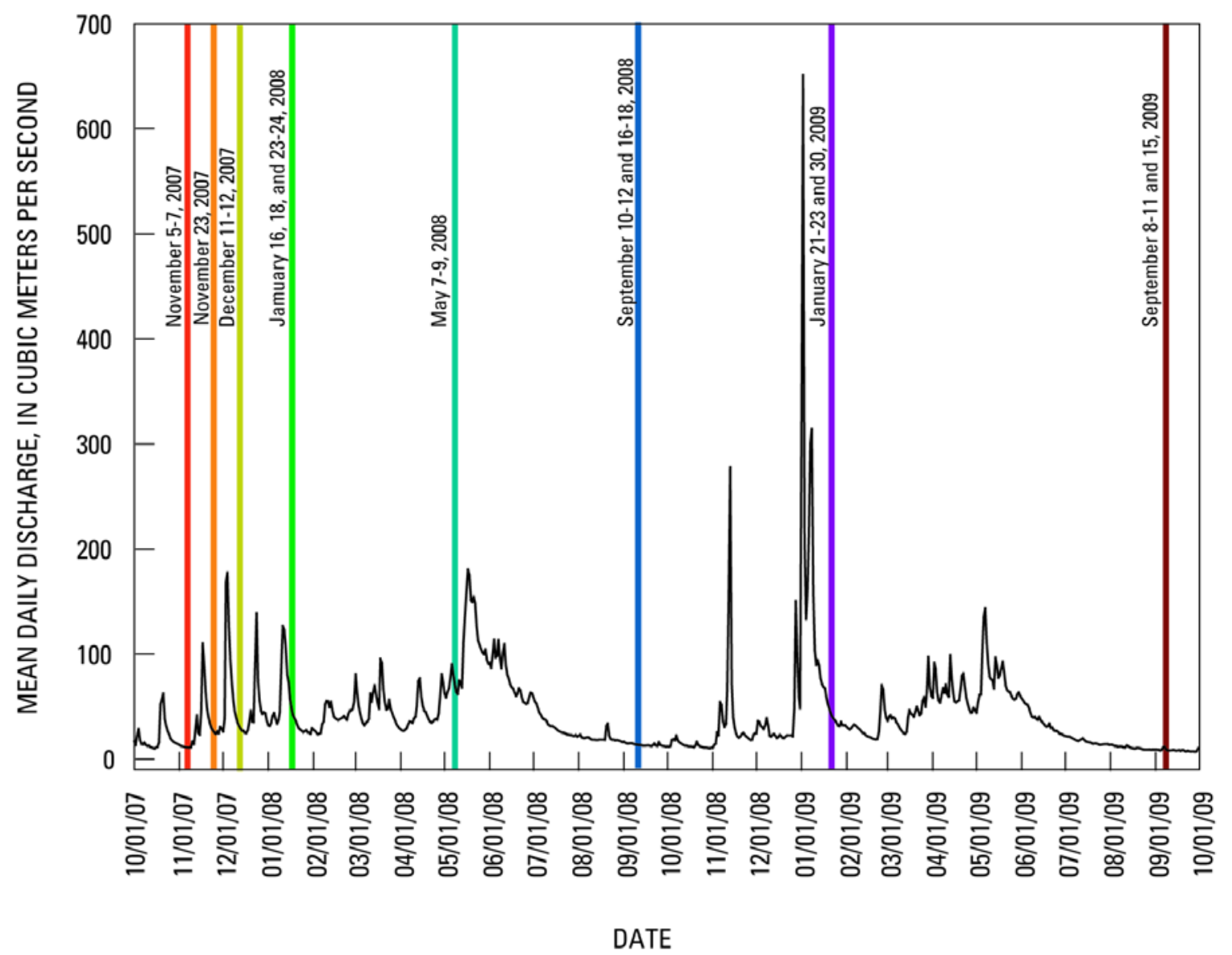

Figure 14. Mean daily discharge from USGS streamflow-gaging station 14137000, Sandy River near Marmot, Oregon and timing of USGS topographic surveys over the two-year period following the removal of Marmot Dam on 19 October, 2007.

profiles along the Reservoir and Beaver Island reaches were used to calculate average channel gradients. Similar to the calculation of widening rates, minimum average incision rates were calculated for each of the $250 \mathrm{~m}$ intervals between the starting dates of consecutive surveys.

Survey errors are estimated to be a function of total station precision $( \pm 1 \mathrm{~cm})$ and accuracy of survey control point coordinates $( \pm 100 \mathrm{~cm})$.Errors associated with 
calculation of gradient and incision rates result from changes in river stage due to variations in river discharge over the survey period (Table 4). The minimum and maximum discharge at streamflow-gaging station 14137000 for water-year 2010 varied from $6.7 \mathrm{~m}^{3} / \mathrm{s}$ to $216.6 \mathrm{~m}^{3} / \mathrm{s}$ (a difference of $209.9 \mathrm{~m}^{3} / \mathrm{s}$ ) translating to an overall stage difference of $4.47 \mathrm{~m}$. The mean daily discharge for surveys used in my analysis range from $8.8 \mathrm{~m}^{3} / \mathrm{s}$ to $81.0 \mathrm{~m}^{3} / \mathrm{s}$ (Table 4 ) which have a maximum difference in stage of about $0.9 \mathrm{~m}$.

Channel changes during and immediately following breaching

Early stages of post-dam-removal channel evolution reveal rapid incision through the reservoir deposit and subsequent widening in the lower reservoir within the first few hours and days following breaching of the coffer dam (Figure 15). Rates of initial incision through the unconsolidated impounded sediment ranged from $1.8 \mathrm{~m} / \mathrm{hr}$ to 12.6 $\mathrm{m} / \mathrm{hr}$ over the first hours. Rates within the lower $100 \mathrm{~m}$ of the Reservoir Reach slowed to an average daily rate of $0.2 \mathrm{~m} / \mathrm{hr}$ on 20 October, the day after the breach, but still attained rates of up to $4.8 \mathrm{~m} / \mathrm{hr}$ at a distance $8 \mathrm{~m}$ upstream of the coffer dam. Incision continued to slow throughout the first 3 days following breaching of the coffer dam. The slowing incision rate coincides with increasing river discharge and is followed by a period, after 22 October, with decreasing discharge (Figure 16) when changes became undetectable from photogrammetry (Figure 17). Two weeks following breaching, bed elevation $8 \mathrm{~m}$ upstream of the coffer dam site had lowered by $7.7 \mathrm{~m}$, and at 49 and $81 \mathrm{~m}$ upstream, it lowered 7.5 and 6.8 m, respectively (Figure 15; Figure 17). 


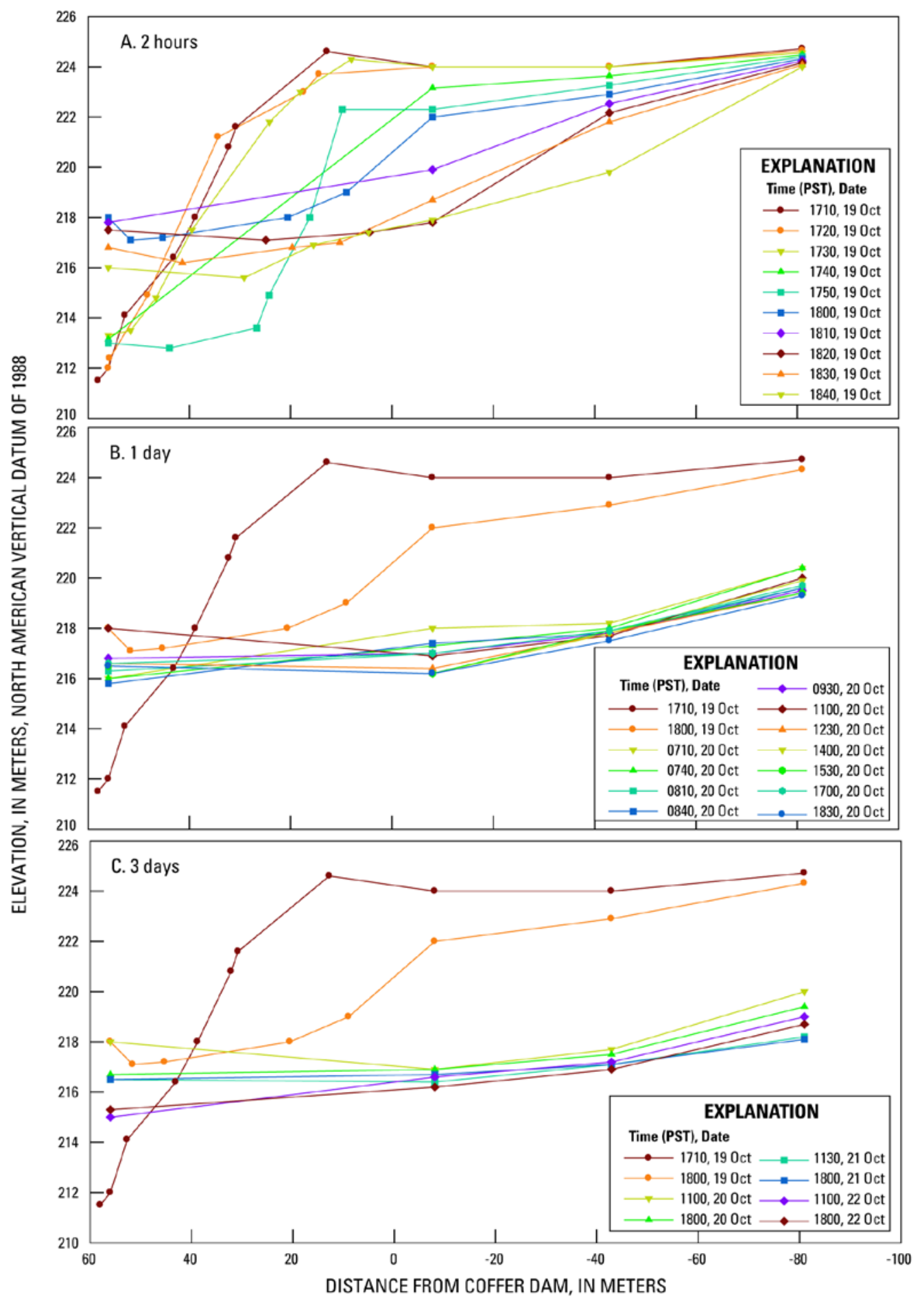

Figure 15. Sandy River water-surface profiles for the lower reservoir derived from photogrammetry for about A) 2 hours, B) 1 day, and C) 3 days following coffer dam breaching which occurred at 1700 PST on 19 October 2007. 


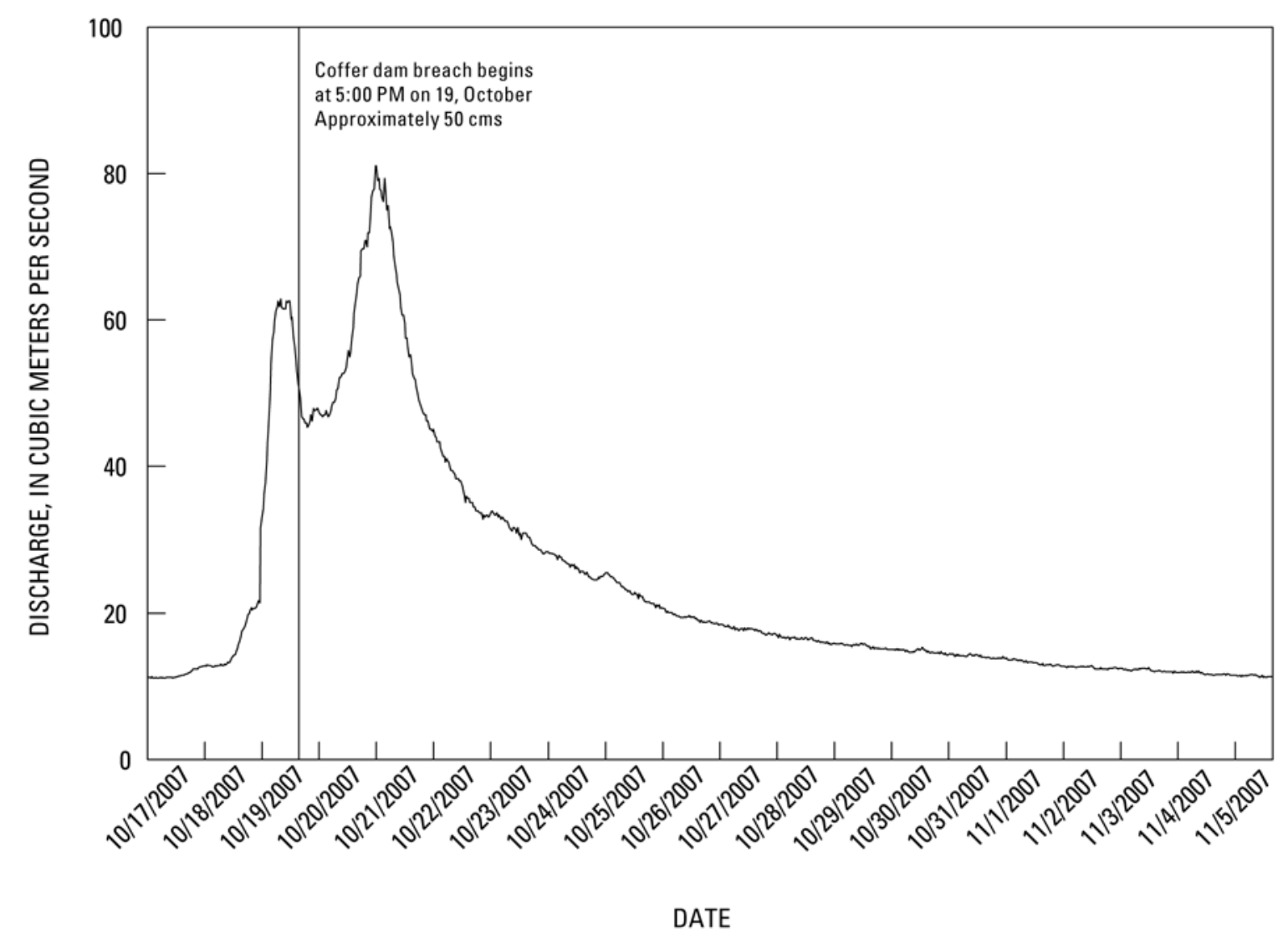

Figure 16. Hydrograph at USGS streamflow-gaging station 14137000 following coffer dam breaching on the Sandy River, Oregon (USGS, 2009b). 


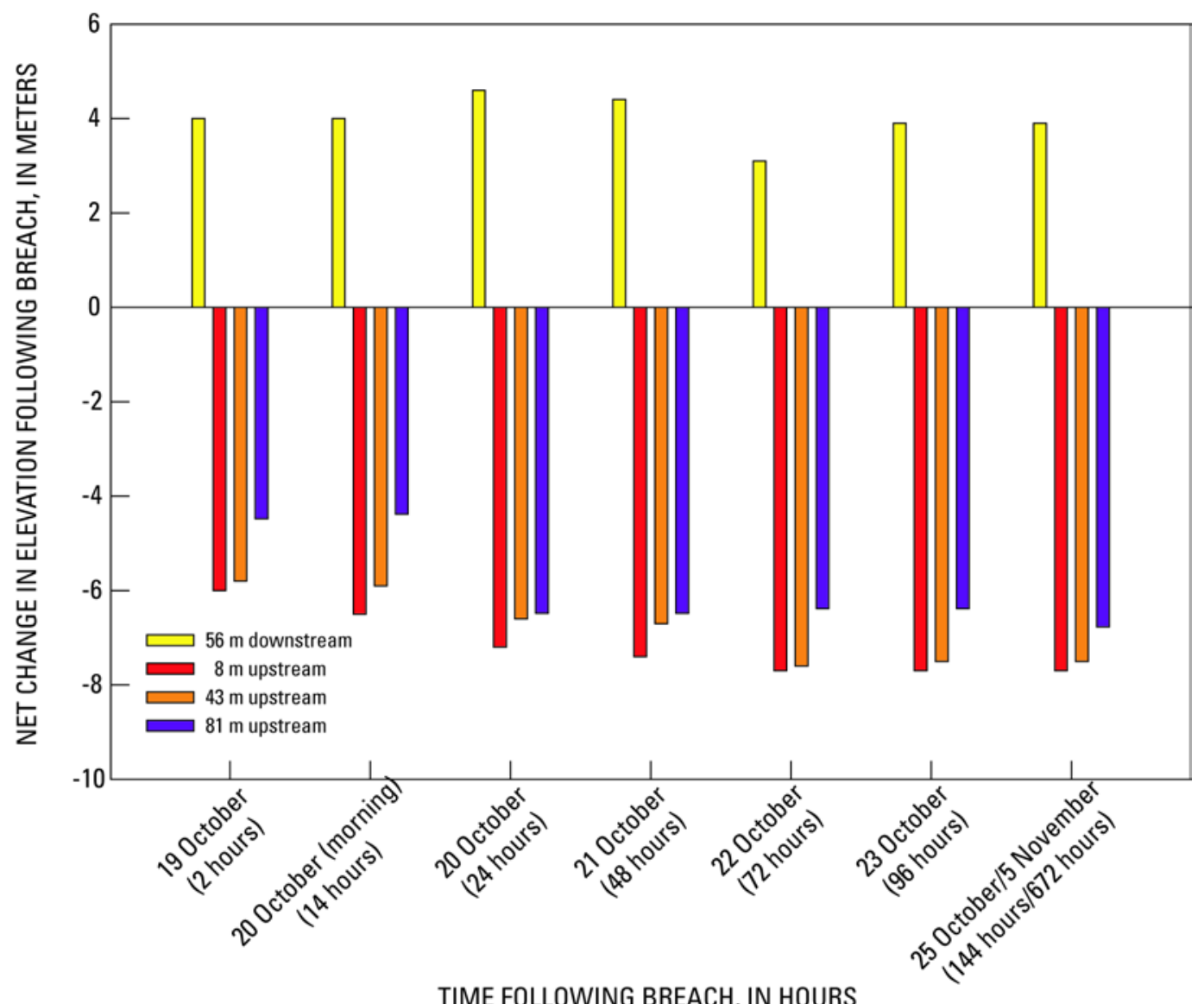

Figure 17. Net change in elevation at four locations measured from time lapse photography following the removal of Marmot Dam on the Sandy River, Oregon. Dates represent the end of the day unless noted. Due to camera station moves, the stations $56 \mathrm{~m}$ downstream and $8 \mathrm{~m}$ upstream of the dam site were only measured through 25 October, 2007, while those at $43 \mathrm{~m}$ and $81 \mathrm{~m}$ upstream of the dam site were monitored through 5 November.

Channel widths $8 \mathrm{~m}$ upstream of the dam decreased sharply from the unchanneled pre-breach width by more than $50 \mathrm{~m}$ in the first 2 hours following breaching and widened approximately $25 \mathrm{~m}$ by the next morning (Figure 18). Widening rates reached $26 \mathrm{~m} / \mathrm{hr}$ in the first day following breaching, slowed to an average $0.4 \mathrm{~m} /$ hour within 3 days, and continued to slow through 5 November 2007. Channel widening 
following dam breaching occurred chiefly through bank collapse as steep banks formed through rapid channel incision.

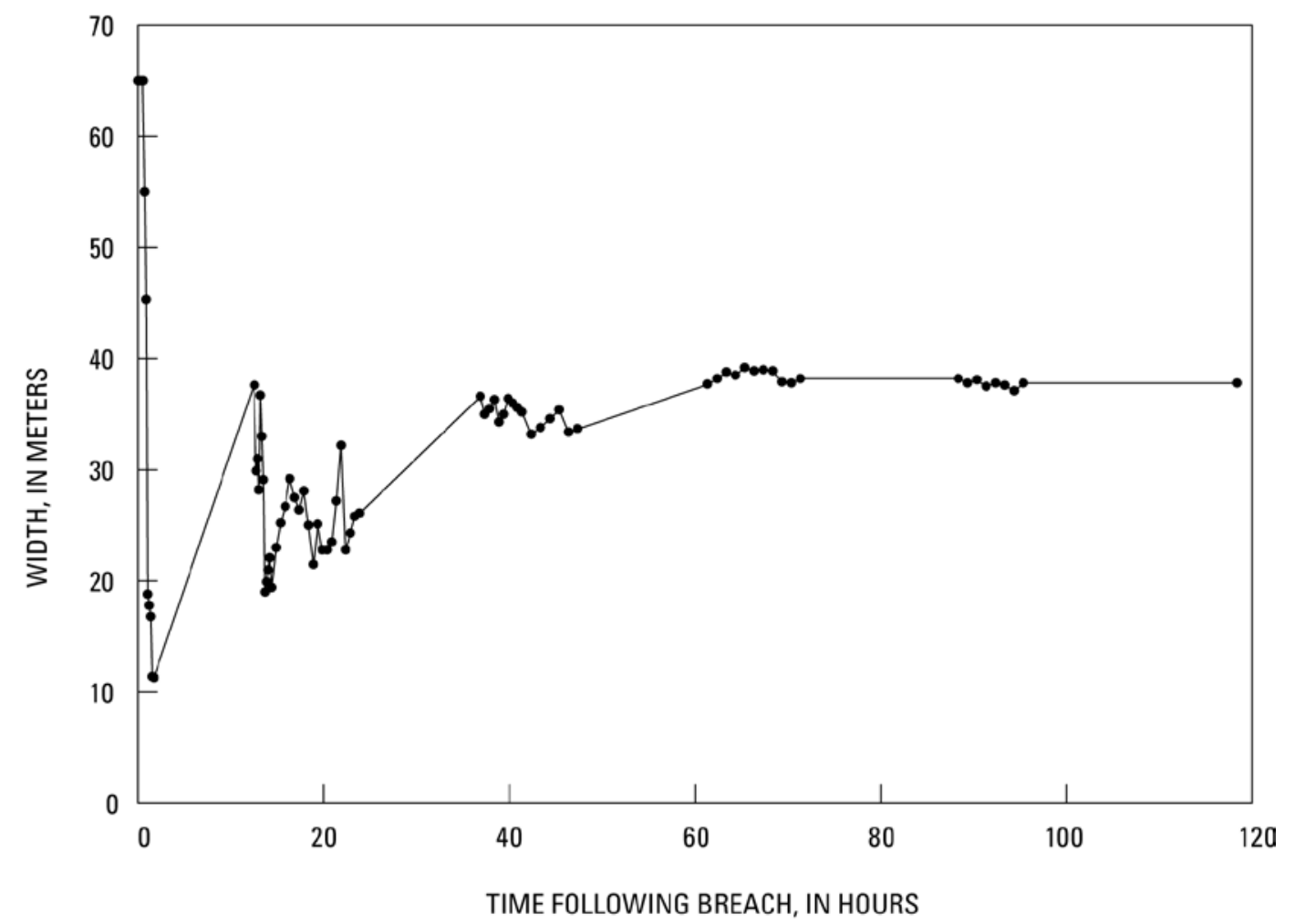

Figure 18. Channel width measured photogrammetrically following breaching of the coffer dam $8 \mathrm{~m}$ upstream the dam site. The initial width is the un-channeled, wetted width prior to coffer dam breaching.

Channel changes 2 weeks to 2 years following dam removal

The first field-based topographic surveys, coinciding and comparing favorably with the last time-lapse photography measurements, confirm increases in channel width of $20 \mathrm{~m}$ to $34 \mathrm{~m}$ and a decrease in water-surface elevation of more than $7 \mathrm{~m}$ in the lower Reservoir Reach near the coffer dam crest during the two weeks following removal. 


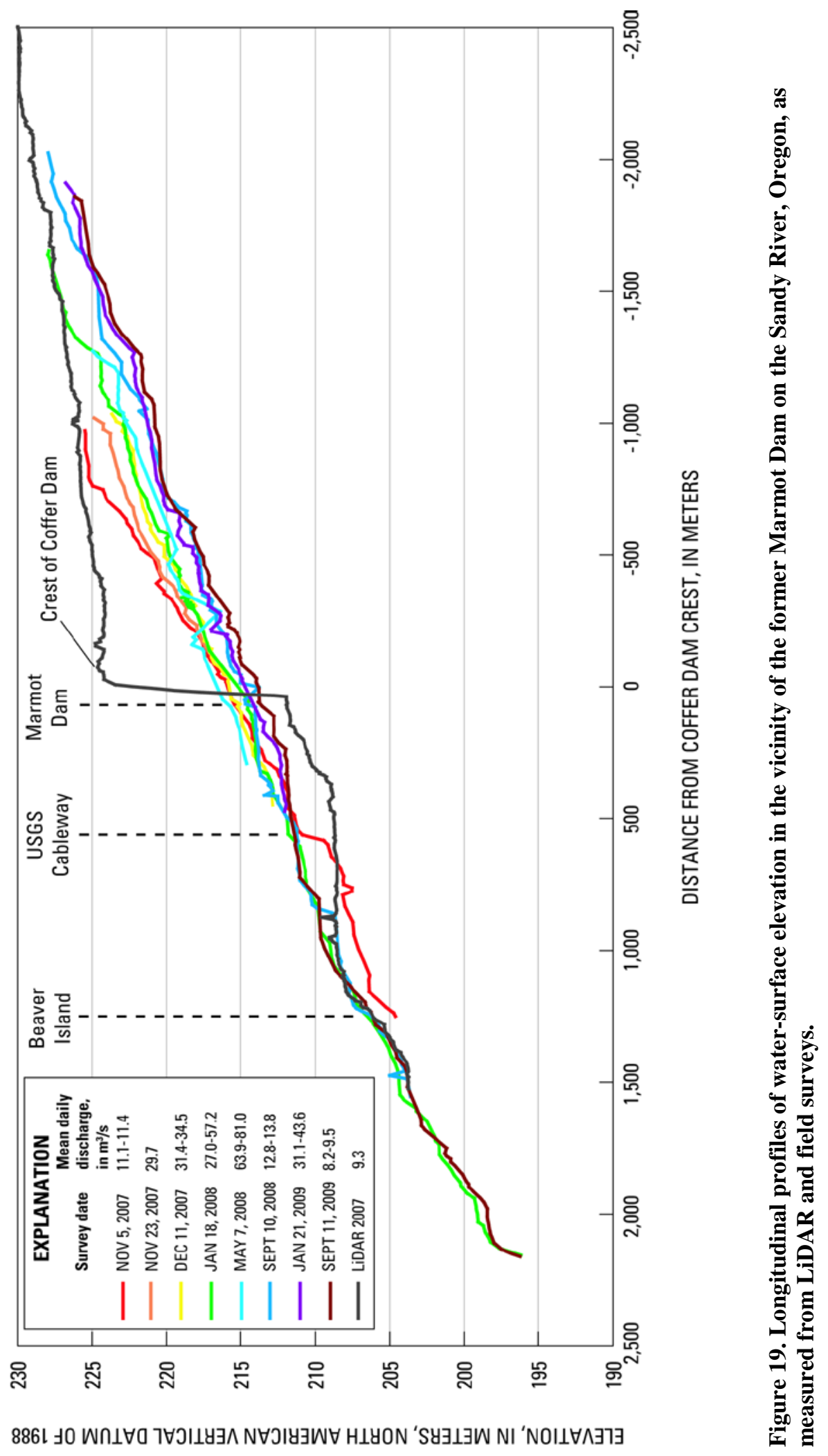


The water-surface gradient in the Reservoir Reach during the 5-7 November 2007 survey was $0.011 \mathrm{~m} / \mathrm{m}$ extending 1,000 $\mathrm{m}$ upstream of the dam site (Figure 19), much steeper than the pre-removal profile of $0.002 \mathrm{~m} / \mathrm{m}$. By the 23 November survey, a slight decrease in water-surface gradient to $0.008 \mathrm{~m} / \mathrm{m}$ extending $1,000 \mathrm{~m}$ upstream occurred. A decrease in water-surface elevation exceeded $1.5 \mathrm{~m}$ about $800 \mathrm{~m}$ upstream of the dam site for the same time period (Figure 20). Surveys on 11-12 December 2007 and 18 January 2008 showed a continual decline in both water-surface gradient $(0.007 \mathrm{~m} / \mathrm{m})$ and rate of incision. Spring snow melt in May 2008, and a high flow event $\left(181 \mathrm{~m}^{3} / \mathrm{s}\right.$ on 17 May 2008), caused another episode of rapid change in the Reservoir Reach. The watersurface gradient through the Reservoir Reach was 0.006 m/m extending 1,400 m upstream, shallower than the previous survey and possibly attributable to the elevated stage of the river associated with higher discharge (Table 4). Incision 1,250 m upstream of the coffer dam was not greater than $1.2 \mathrm{~m}$ since the previous survey (Figure 20). Average daily flow did not exceed $181 \mathrm{~m}^{3}$ /s over the 2008 summer and was usually far less. The mean monthly flow for June, July, and August 2008 was $77.4 \mathrm{~m}^{3} / \mathrm{s}, 32.4 \mathrm{~m}^{3} / \mathrm{s}$, and $20.1 \mathrm{~m}^{3} / \mathrm{s}$, respectively. The 11 September 2008 survey shows a slight increase in gradient to $0.007 \mathrm{~m} / \mathrm{m}$ and additional incision of $1.4 \mathrm{~m}$ at a location about $1,200 \mathrm{~m}$ upstream of the dam site (Figure 20), although differences in discharge (as much as 68 $\mathrm{m}^{3} / \mathrm{s}$ ) between these surveys (Table 4 ) add to uncertainty. Changes within the Reservoir Reach through January 2009 were still substantial but minor in comparison to changes taking place in the first three months following breaching of the coffer dam. Nearly two 
years after breaching, a September 2009 survey indicates a Reservoir Reach gradient remaining at about $0.006 \mathrm{~m} / \mathrm{m}$ (Figure 19), and incision between $800 \mathrm{~m}$ and 1,000 m upstream of the dam site exceeding $4.6 \mathrm{~m}$ since the first November 2007 survey. As much as 1.9 m of incision occurred in the upper Reservoir Reach during the second year at a location 1,800 m upstream (Figure 20).

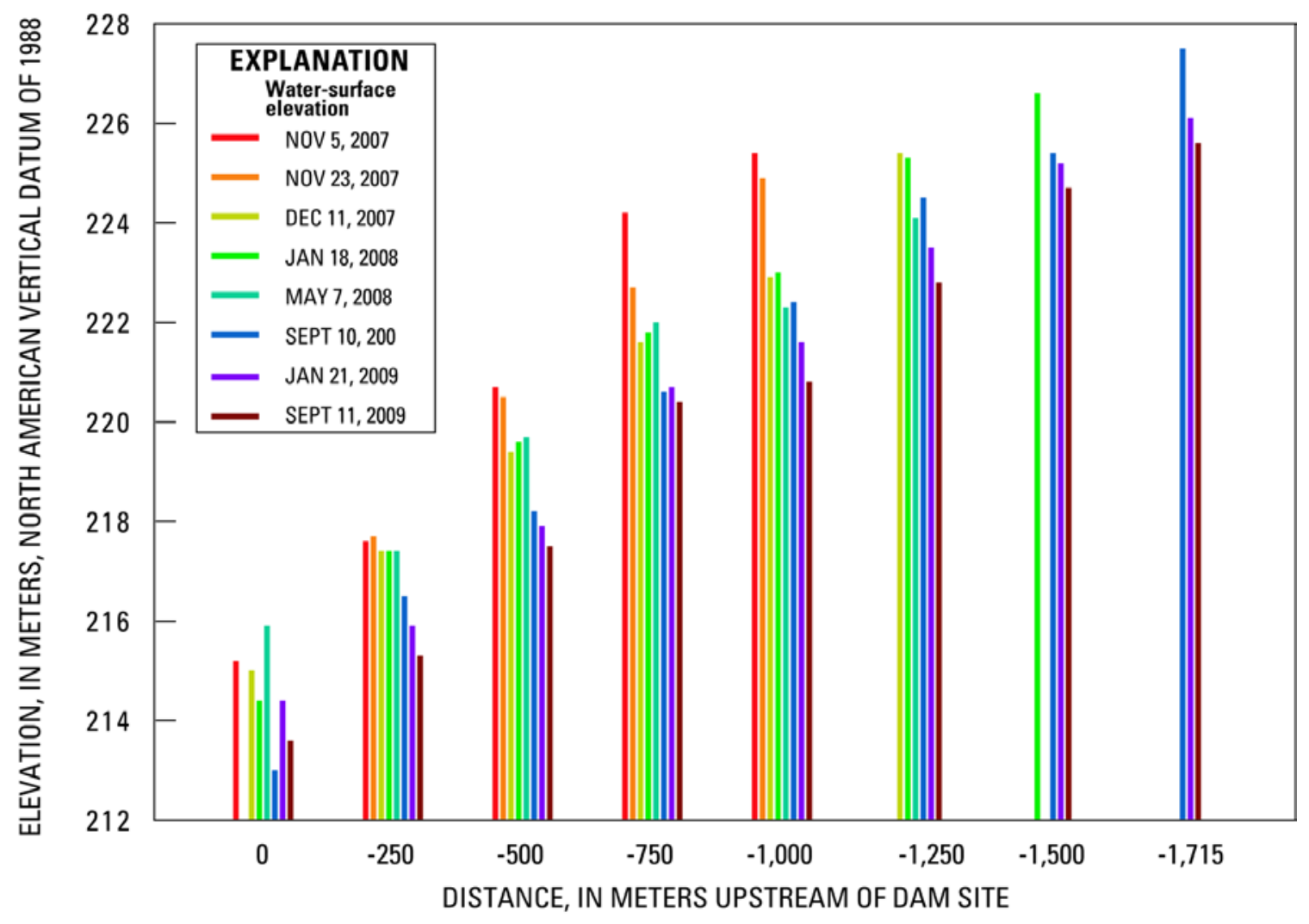

Figure 20. Water-surface elevation during the 2 years following the removal of Marmot Dam on the Sandy River, Oregon.

Channel widening in the Reservoir Reach followed a pattern similar to that of channel incision; rapid changes in width occurred shortly after dam removal and were 
followed by diminishing rates of widening. The greatest change in channel width was measured between the two November surveys, with increases in width varying from 13.4 $\mathrm{m}$ at a location $250 \mathrm{~m}$ upstream of the dam site to $2.5 \mathrm{~m}$ at a location $750 \mathrm{~m}$ upstream (Figure 21). Overall, rates of channel widening remained high through the winter as runoff increased. Minimum daily average rates varied up from $0.74 \mathrm{~m} /$ day through December 2007 to $0.11 \mathrm{~m} /$ day through January 2008. Continual failure of oversteepened banks in the Reservoir Reach contributed to extensive channel widening. By May 2008, the channel had increased in width by more than $30 \mathrm{~m}$ since 5 November 2007 at a location $750 \mathrm{~m}$ upstream of the dam site. Channel-width adjustments were still evident in summer 2008, but to a far less degree likely due to decreased discharges and depletion of reservoir sediment. The Sandy River channel widened through the lower 1 $\mathrm{km}$ of the Reservoir Reach by as much as $31 \mathrm{~m}$ in the year following removal, but only about $5 \mathrm{~m}$ of that width increase occurred after May 2008 (Figure 21). Channel width increased slightly with the onset of high river discharges at the beginning of water year 2009 (1 October, 2008 through 30 September, 2009), in the middle Reservoir Reach and widened by as much as $21 \mathrm{~m}$ after a 5-year flood event in January 2009 at locations 500 $\mathrm{m}$ to $750 \mathrm{~m}$ upstream of the dam site (Figure 3). Following the January 2009 flood, channel width in the Reservoir Reach remained relatively stable. Approximately 2 years following the removal of Marmot Dam, widths of the Reservoir Reach widths averaged $50 \mathrm{~m}$ to $90 \mathrm{~m}$ (Figure 21), as compared to 30 to $60 \mathrm{~m}$ measured two weeks after breaching of the coffer dam. 


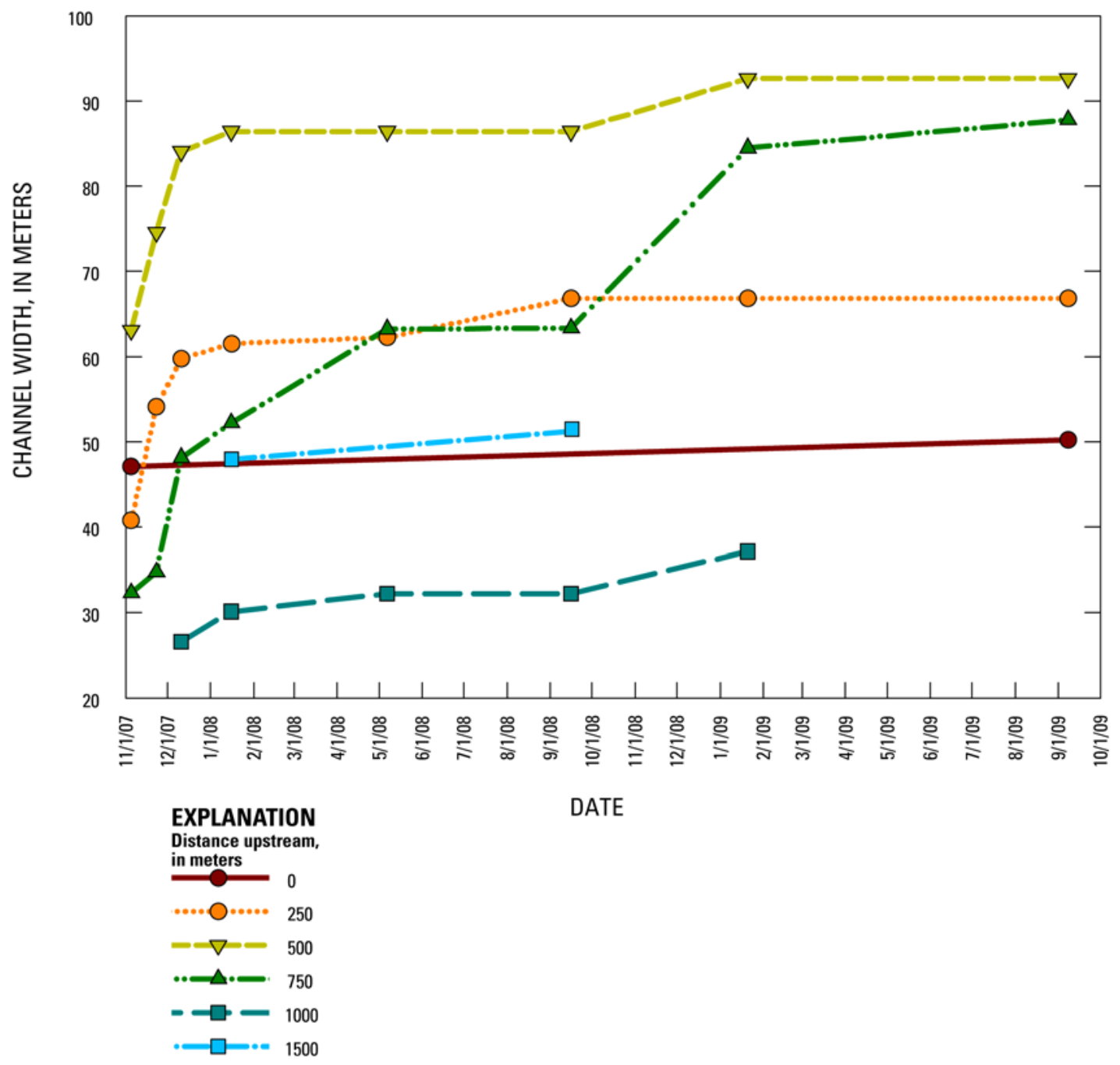

Figure 21. Active channel width within the Reservoir Reach following the removal of Marmot Dam. 


\section{Chapter V: Reservoir erosion and volume change}

LiDAR acquired in the autumn of 2007 and 2008, repeat field-based surveys, and repeat cross-sectional surveys collected annually between 2005 and 2009, at about 200-m spacing through the Reservoir Reach (Table 3), were used to estimate volumetric changes in sediment erosion and its temporal and spatial patterns. Comparisons among datasets were made in ArcGIS 9.3 by constructing surfaces and then differencing those surfaces. All data sets were first converted to a common projection (UTM NAD 83) and vertical unit of measure (meters) before surfaces were constructed and differenced.

A pre-removal reservoir surface and post-removal surface approximately one year after removal were defined with LiDAR. The cross-sectional data were used in watersurface regions to define bathymetric channel changes. The differences in cross-sectional areas between the two data sets were integrated in Excel. Cross-sectional areas were inferred to be linear interpolations between DEA transects, and those areas were multiplied by one half the distances to the upstream and downstream adjacent cross section to estimate volumes. These volumes were later used in calculations to estimate Reservoir Reach erosion. The surface for conditions approximately two years following dam removal was based on field surveys completed in September 2009. Point data were interpolated to create this surface. The spatial density of ground elevations obtained by field surveys is sparse compared to the LiDAR data.

Intermittent field surveys were also conducted to derive erosion estimates after major high flow events. A triangulated irregular network (TIN) was created in ArcGIS 
9.3 from surveys. Cross-section information provided in these surveys is limited by river discharge conditions at the time of a survey. Bathymetry could not be measured, so the volume of sediment below water surface was assumed constant between surveys where the collection period did not coincide with cross-section survey collection (Table 4).

Erosion volume was computed by subtraction of raster surfaces using the 'Cut/Fill’ Spatial Analyst tool in ArcGIS 9.3. Results were exported to Excel for each area analyzed and summed to determine net change in volume. The water volume in the pre-breach reservoir was subtracted in this step.

Error introduced during data collection, interpolation, and surface subtraction varied with source. The average error in vertical elevation between the 2007 and 2008 LiDAR surveys was $0.23 \mathrm{~m}$ and ranged up to $0.3 \mathrm{~m}$ (Moore-Cookes, 2009), whereas Major and others (in press) use a conservative estimate of vertical error of $0.33 \mathrm{~m}$ from LiDAR surveys. I adopt a constant value of $0.33 \mathrm{~m}$ as an estimate even though errors in surface differencing are greatest in regions of relatively high relief. This is because steep surfaces have lower point density data per surface area, and therefore, a higher uncertainty (Wheaton and others, 2010). Maximum relief in the 2007 LiDAR occurs at the face of the coffer dam, 14 m over 55 m. Many of the steep channel banks in the 2008 LiDAR survey likely account for the greatest vertical error; although, relatively flat channel and terrace surfaces that bound steep banks constrain this vertical error.

Four major assumptions were made when combining data sets to create the topographic surfaces for volumetric change estimates. 1) Though river stage varied 
among topographic field surveys (Table 4) and translated to uncertainty in interpolated surfaces, resulting potential erosion or deposition between surveys was assumed negligible and no adjustments were made to calculated volume. 2) Although the dates of cross-sectional survey collection do not coincide with the 2007 and 2008 LiDAR and the September 2008 field survey (Table 4), these were low flow periods and no channel change was assumed negligible between these periods. 3) The spatial extent of fieldbased topographic surveys was assumed to capture the farthest upstream extent of Reservoir Reach change at a time of the survey. This is a valid assumption until the September 2009 survey, when erosion extended upstream, beyond the limits of the surveys. 4) Topographic and bathymetric coverage in the reach between the Marmot Dam and coffer dam was limited and calculated only for two weeks, one year, and two years after breaching. Erosion in this reach, between two weeks and one year following breaching, was assumed to occur during the 17 November and 3 December 2007 storm flows as indicated by little change between the December 2007 and January 2008 field surveys. The calculated volume was added to Reservoir Reach erosion volumes for those time periods. 
Reservoir Reach erosion volume change and rate

Differencing of surfaces from the 2007 LiDAR survey and first USGS survey (5 November, 2007) indicates that about 17 percent of the impounded sediment, 125,000 $\mathrm{m}^{3}$ had mobilized in less than 17 days (Table 5), with rates averaging 7,300 $\mathrm{m}^{3} / \mathrm{d}$. Examination of the hydrograph and time-lapse photography indicate that the majority of that erosion occurred within the first 60 hours following breaching; yielding erosion rates up to $50,000 \mathrm{~m}^{3} / \mathrm{d}$ (Table 5; Figure 22).

Table 5. Reservoir erosion volumes following the removal of Marmot Dam on the Sandy River, Oregon. [Abbreviations: $\mathrm{m}^{3}$, cubic meters; d, day]

\begin{tabular}{lcccccc}
\hline \multicolumn{1}{c}{ Date } & $\begin{array}{c}\text { Eroded Volume } \\
\left(\mathbf{m}^{3}\right)\end{array}$ & $\begin{array}{c}\text { Cumulative Volume } \\
\left(\mathbf{m}^{3}\right)\end{array}$ & $\begin{array}{c}\text { Percent } \\
\text { of } \\
\text { Deposit }\end{array}$ & $\begin{array}{c}\text { Erosion } \\
\text { Rate } \\
\left(\mathbf{m}^{3} / \mathbf{d}\right)\end{array}$ & $\begin{array}{c}\text { Gravel Volume* } \\
\left(\mathbf{m}^{3}\right)\end{array}$ & Sand Volume* $\left(\mathbf{m}^{3}\right)$ \\
\hline Nov 2007a & $125,000 \pm 17,000$ & $125,000 \pm 17,000$ & 17 & 7,350 & $57,000 \pm 17,000$ & $56,000 \pm 17,000$ \\
Nov 2007b & $82,000 \pm 4,000$ & $207,000 \pm 19,000$ & 28 & 4,560 & $85,000 \pm 19,000$ & $88,000 \pm 19,000$ \\
Dec 2007 & $79,000 \pm 3,000$ & $286,000 \pm 22,000$ & 39 & 4,330 & $120,000 \pm 22,000$ & $126,000 \pm 22,000$ \\
Jan 2008 & $42,000 \pm 2,000$ & $328,000 \pm 25,000$ & 45 & 1,170 & $139,000 \pm 25,000$ & $146,000 \pm 25,000$ \\
May 2008 & $20,000 \pm 1,000$ & $348,000 \pm 24,000$ & 48 & 180 & $147,000 \pm 24,000$ & $156,000 \pm 24,000$ \\
Sept 2008 & $25,000 \pm 1,000$ & $373,000 \pm 26,000$ & 51 & 200 & $163,000 \pm 26,000$ & $178,000 \pm 26,000$ \\
Jan 2009 & $43,000 \pm 1,000$ & $416,000 \pm 27,000$ & 57 & 320 & $177,000 \pm 27,000$ & $190,000 \pm 27,000$ \\
Sept 2009 & $6,000 \pm 1,000$ & $422,000 \pm 26,000$ & 58 & 30 & $184,000 \pm 26,000$ & $203,000 \pm 26,000$ \\
\hline
\end{tabular}

*Estimated 48-55 percent sand fraction (Squier Associates, 2000) 


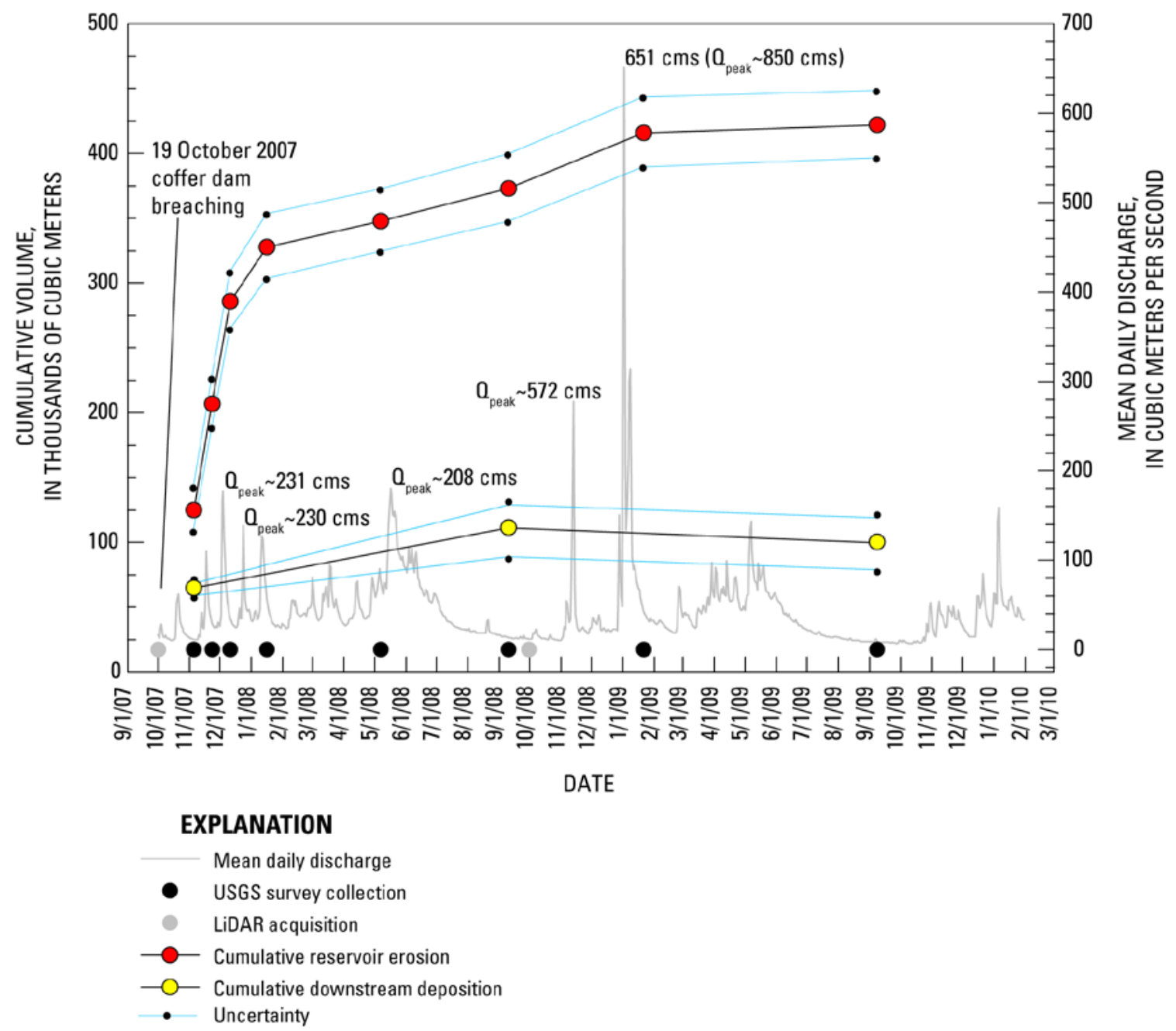

Figure 22. Cumulative reservoir erosion and downstream deposition two years following the removal of Marmot Dam including variation in discharge and collection dates for USGS and LiDAR surveys used to measure the change in volume.

Following breaching, the majority of erosion likely occurred during high flow events. The volume of sediment eroded by the first storm following breaching, 17 November 2007, which peaked at $175 \mathrm{~m}^{3}$ /s (USGS, 2009b), was measured at 82,000 $\mathrm{m}^{3}$ accounting for another 11 percent of volume initially impounded. The elapsed time since the previous survey was 17 days, yielding an average erosion rate of about 4,600 m³ $\mathrm{d}$. 
By 11 December 2007, the cumulative erosion had reached 286,000 $\mathrm{m}^{3}$, accounting for more than $1 / 3$ of the impounded sediment volume and an additional 11 percent since the previous survey, probably taking place during the 3 December flow event (231 m³ $/ \mathrm{s}$ ). Average erosion rates declined by about 73 percent between 11 December 2007 and the following survey on 16 January 2008. The additional 6 percent of eroded reservoir volume was likely attributable to two storm events, 23 December 2007 and 12 January 2008 (Figure 22, Table 5).

Nearly 50 percent of the impounded sediment had eroded by May 2008, and that amount remained unchanged through September 2008. Moderate flows in November $2008\left(\right.$ peak discharge $\left.=572 \mathrm{~m}^{3} / \mathrm{s}\right)$ and January $2009\left(\right.$ peak discharge $=651 \mathrm{~m}^{3} / \mathrm{s}$ ) cumulatively eroded approximately $43,000 \mathrm{~m}^{3}$, an amount similar to that eroded by a storm in January 2008, which had a peak discharge of $138 \mathrm{~m}^{3} / \mathrm{s}$. By September 2009, approximately 2 years following breaching about 422,000 $\mathrm{m}^{3}$, 58 percent, of impounded sediment had eroded (Figure 22, Table 4).

The erosion between the coffer dam and former site of Marmot Dam probably occurred during the storm events of 20 October, 17 November, and 3 December 2007. Although perhaps unrealistic, the volume change between the coffer dam and former dam site accounts for less than 1 percent of the estimated total erosion. The volume eroded during the second year following breaching is also less than 1 percent of the total volume eroded and probably occurred in a high flow in January 2009 (Figure 22). The rate of erosion from the Reservoir Reach rapidly decreased with time (Figure 22). 
Actual erosion rates are likely higher than the minimum average rates because sediment transport typically occurs in pulses that coincide with high discharge. At the USGS cableway ( $0.4 \mathrm{~km}$ downstream of the dam site) bed-load flux rates of up to $70 \mathrm{~kg} / \mathrm{s}$ (about 3,600 m³ d) were measured during the November 2007 and May 2008 high flows and were likely on the order of several hundred kg/s during the December 2007 event (Major and others, 2010a; Major and others, in press). A bed-load flux rate of $260 \mathrm{~kg} / \mathrm{s}$ (about 11,600 m³/d) was measured at Revenue Bridge in December 2007 (Pittman and Matthews, 2008; Major and others, in press).

Erosion varied with time longitudinally through the reach. Between $0 \mathrm{~m}$ and 620 m upstream of the dam site (Figure 23A, B, C), channel adjustments are greatest during the first year following breaching, and only minimal adjustments occur the second year. However, at locations $850 \mathrm{~m}$ and 1,290 $\mathrm{m}$ upstream of the dam site (Figure 23D, E), cross-sectional differences show roughly equal magnitude of change occurred in the first and second years following breaching. At 2,180 m upstream of the dam site (Figure 23F), minimal channel change was observed until during the second year. 

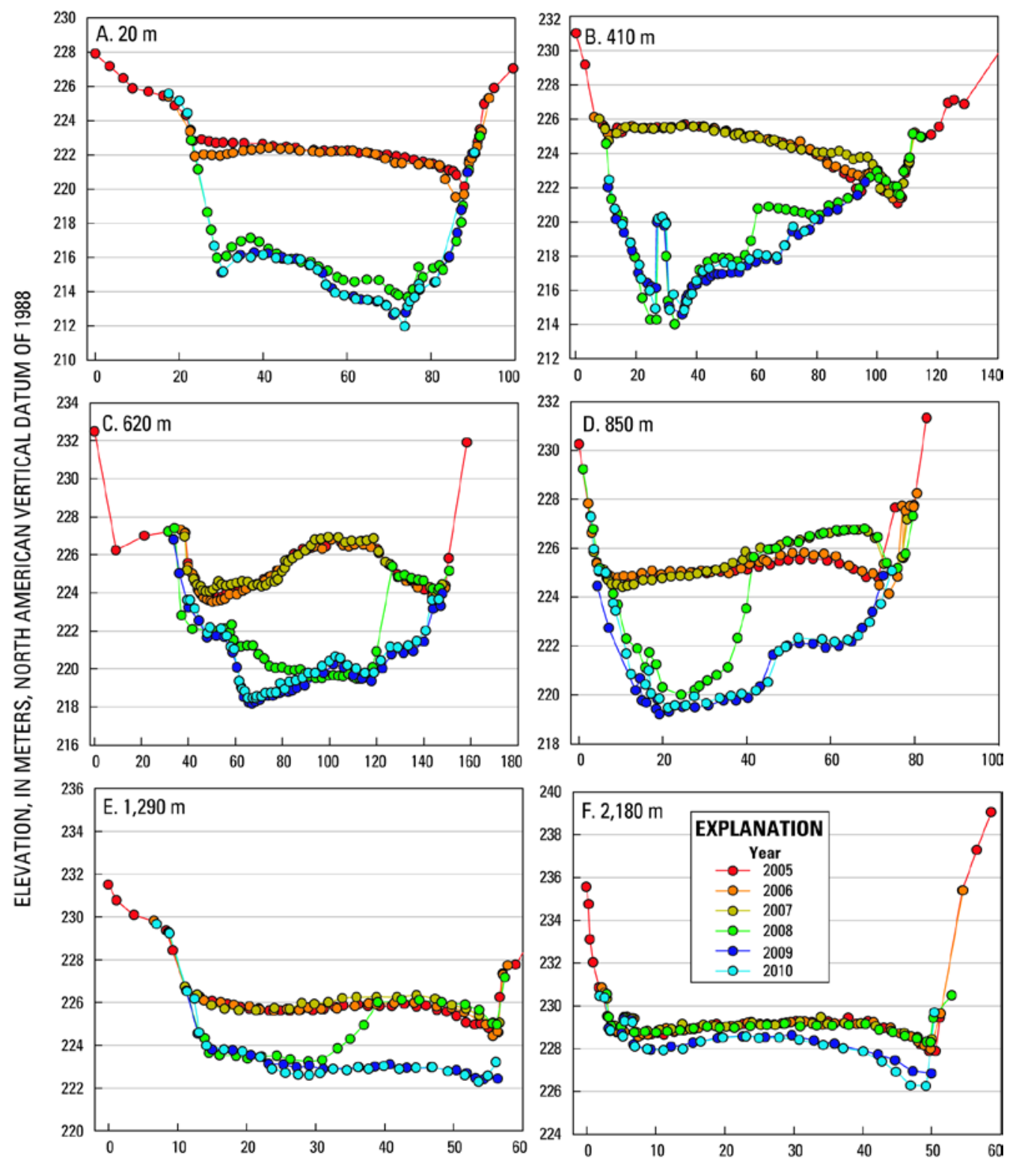

DISTANCE, IN METERS FROM LEFT TO RIGHT BANK

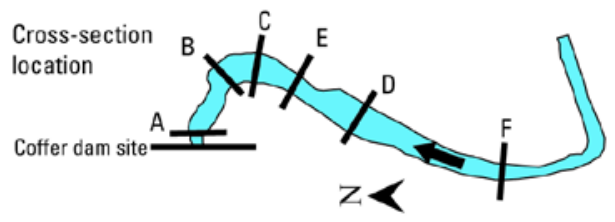

Figure 23. Select annual David Evans and Associates (DEA) cross sections at A) 20 m, B) $410 \mathrm{~m}, \mathrm{C}$ ) $620 \mathrm{~m}, \mathrm{D}) 850 \mathrm{~m}, \mathrm{E}) 1,290 \mathrm{~m}$, and F) 2,180 $\mathrm{m}$ upstream of the coffer dam site. Data from DEA (2005, 2006, 2007, 2008, 2009, 2010). 
Although approximately $125,000 \mathrm{~m}^{3}$ of sediment was evacuated from the Reservoir Reach within 60 hours of breaching, only about 50 percent of that volume was deposited in a 2-km-long sediment wedge that formed in the Beaver Island Reach. The remaining sediment passed into the Sandy River gorge. Coarse, gravel-sized sediment was likely deposited in pools in the gorge while sand and finer-sized sediment was transported downstream. One year following breaching, an additional 35,000 $\mathrm{m}^{3}$ was deposited in that wedge, and after two years there was a net decrease of 5,000 $\mathrm{m}^{3}$ (Major and others, in press). 


\section{Chapter VI: Changes in Bed Material and Bar Morphology}

Bed-material size and bar morphology evolved as the Sandy River incised

through the reservoir sediment. To measure the changes, pre- and post-dam bars were mapped from LiDAR, and surface and subsurface grain size distributions were collected following breaching. Characteristics of the impounded sediment are known (Squier Associates, 2000) and provided a basis against which post-removal sediment and characteristics were compared. Pre-removal grain-size information is summarized in Chapter II.

Several surfaces, some abandoned and some active, in the Reservoir Reach were created when the Sandy River incised through the reservoir deposit. These surfaces are a collection of terraces, high-elevation floodplain bars, and actively changing gravel bars nearer to water level. Distinct bar surfaces were delineated from pre-removal and postremoval LiDAR at a scale of 1:5,000 based on texture, elevation, and slope within the lower Reservoir Reach.

Bed-material samples were collected at 15 sites in the Reservoir Reach and at 6 sites below the dam site between January 2008 and April 2010 (Appendix C); only the Reservoir Reach samples are discussed. Each collection site was recorded with a Garmin CSX60 GPS or by field survey. Sampling transects were made along a bar surface. The lengths of sampling lines and number of lines varied with bar size. Repeat surface pebble counts of bed material were collected using a modified grid technique (Wolman, 1954; Kondolf and others, 2003) to characterize clast-size distributions on bars. These 
gravel bars were the channel bed for various periods of time during channel incision. Grain-size distribution is important to know because it can yield information about how sediment transport has changed over time. In general, the surface grain-size distribution of a bar is proportional to the caliber of sediment that is transported by the river. Coarser bars indicate coarser sediment is being transported. Additionally, comparison of the surface to subsurface distributions can indicate whether a river is transport or supply limited or whether there is a balance between supply and transport.

The b-axis, the intermediate perpendicular axis of measurement for a clast, of each sample was measured with a ruler, and approximately 100 clasts were sampled from each gravel bar, although a few samples consisted of fewer clast measurements (Table C1). Reproducibility associated with clast measurement may be of concern, and it has been shown that sample sizes consisting of 100 clasts will generally produce consistent results between measurements (Wolman, 1954; Kondolf and others, 2003); however, larger sample sizes further reduce operator measurement bias (Kondolf and others, 2003). Particles smaller than 2 mm are not measurable by pebble count method (Bunte and Abt, 2001; Leopold, 1970), and were simply recorded as less than $2 \mathrm{~mm}$. When a particle was too large to be picked up for measurement, the shorter of the two exposed axes was measured, as the c-axis (shortest perpendicular axis) is commonly perpendicular to ground surface (Leopold, 1970).

Each clast size was binned into half-phi categories according to the Wentworth (1922) sediment-size gradation scale (Table 6). For example, a clast b-axis measuring 59 
mm was grouped with other clasts finer than $64 \mathrm{~mm}$ but larger than $45 \mathrm{~mm}$. Various metrics were derived from grain-size measurements collected by surface and subsurface (method described below) sediment sampling. The $16^{\text {th }}, 50^{\text {th }}$, and $84^{\text {th }}$ percentiles $\left(\mathrm{D}_{\mathrm{i}}\right)$ were determined from the sediment data for each bed-material sample. Additionally, the median grain size for the gravel fraction was determined, excluding sand (particles less than $2 \mathrm{~mm}$ in diameter).

Table 6. Grain size classes used to bin particle count data. [Abbreviations: mm, millimeters]

\begin{tabular}{|c|c|c|c|}
\hline $\begin{array}{l}\text { Wentworth } \\
\text { Classification } \\
\text { System }\end{array}$ & $\begin{array}{c}\text { AGU } \\
\text { Classification } \\
\text { System }\end{array}$ & $\begin{array}{c}\text { Grain Size } \\
\text { Finer Than } \\
(\mathrm{mm})\end{array}$ & $\begin{array}{l}\text { Phi Size } \\
\text { Finer Than }\end{array}$ \\
\hline \multirow{3}{*}{ Boulder } & Large boulders & 1024 & -10.0 \\
\hline & \multirow{2}{*}{ Small boulders } & 512 & -9.0 \\
\hline & & 360 & -8.5 \\
\hline \multirow{4}{*}{ Cobble } & \multirow{2}{*}{ Large cobbles } & 256 & -8.0 \\
\hline & & 180 & -7.5 \\
\hline & \multirow{2}{*}{ Small cobbles } & 128 & -7.0 \\
\hline & & 90 & -6.5 \\
\hline \multirow{8}{*}{ Pebble } & \multirow{2}{*}{$\begin{array}{l}\text { Very coarse } \\
\text { gravel }\end{array}$} & 64 & -6.0 \\
\hline & & 45 & -5.5 \\
\hline & \multirow{2}{*}{ Coarse gravel } & 32 & -5.0 \\
\hline & & 22.6 & -4.5 \\
\hline & \multirow{2}{*}{ Medium gravel } & 16 & -4.0 \\
\hline & & 11 & -3.5 \\
\hline & \multirow{2}{*}{ Fine gravel } & 8 & -3.0 \\
\hline & & 5.6 & -2.5 \\
\hline \multirow{2}{*}{ Granule } & \multirow{2}{*}{ Very fine gravel } & 4 & -2.0 \\
\hline & & 2.8 & -1.5 \\
\hline $\begin{array}{l}\text { Very coarse sand } \\
\text { and finer }\end{array}$ & $\begin{array}{l}\text { Very coarse } \\
\text { sand and finer }\end{array}$ & 2 & -1.0 \\
\hline
\end{tabular}

Mass and additional grain-size distribution data measured by myself, National Center for Earth Dynamics (NCED) undergraduate interns, and the USGS during 2009 
and 2010 were used to supplement this study’s grain-size data. Bulk sampling of subsurface sediment and surficial pebble counts provide constraints on mass distribution of subsurface material as well as armoring ratios (ratio of $\mathrm{D}_{50}$ surface to $\mathrm{D}_{50}$ subsurface). Additionally, the subsurface bulk density was estimated from the total sample mass and measured volume of an excavated pit. Bulk subsurface grain-size data were derived from field sieving of particles with $8 \mathrm{~mm}, 16 \mathrm{~mm}$, and $32 \mathrm{~mm}$ sieves as well as using a squarehole gravel template, gravelometer, for measurement of larger grain sizes. Grains were excavated from an approximate $1 \mathrm{~m}^{3}$ pit, sieved, and weighed.

The timing of terrace formation in the Reservoir Reach can be constrained by the USGS repeat surveys and by the early morphologic developments captured in the timelapse photography. The repeat surveys defined different terraces, as well as other features such as bars and water’s edge, within the Reservoir Reach. Furthermore, survey dates that constrain terrace development can be linked to the spatial location of surficial grain-size data. The relative heights of terraces and bed-material sampling transects were referenced to the elevation of the water surface measured in the 2008 post-removal LiDAR. Dates associated with terrace formation were then tied to the relative height above that water-surface elevation.

I examined changes in surface grain-size distributions following dam removal in three ways: 1) vertical trends in size-distribution response to channel incision, 2) longitudinal trends in response to headward erosion, and 3) temporal variance in grainsize distribution on the same surface. 
Mapping of reservoir surfaces from pre- and post-removal LiDAR showed an increase in the number bars and bar area exposed in the year following breaching of the coffer dam. In 2007, prior to dam removal, six bars were visible in the lower $\sim 1,700 \mathrm{~m}$ of the Reservoir Reach. Approximately 16 different surfaces can be depicted on those bars in the 2007 LiDAR image. In 2008, by contrast, approximately 56 surfaces can be depicted in the post-removal LiDAR image. The bars prior to dam removal covered a surface area of approximately 38,600 m², whereas those exposed in 2008 covered 55,000 $\mathrm{m}^{2}$ (Figure 24). 


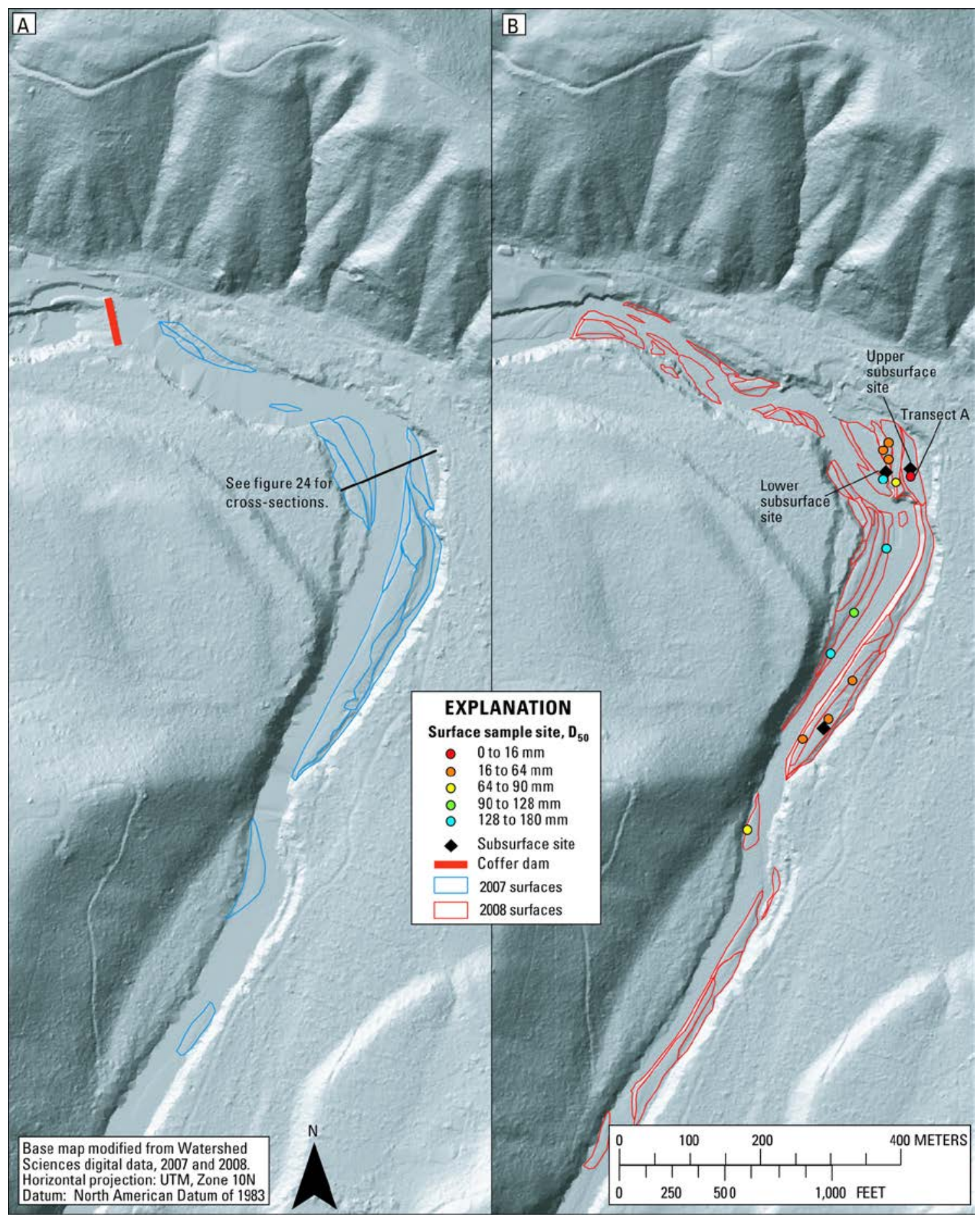

Figure 24. Outline of distinct reservoir bar surfaces mapped from aerial photography and LiDAR for A) pre-removal of Marmot Dam in 2007 and B) post-removal, about one year later in 2008. Reservoir bed-material surface sampling sites are shown on $B$ and colored by median grain size. The point locations represent the upstream coordinate of transect. 
Surficial bed-material sampling within the Reservoir Reach illustrates a wide range of clast sizes dependent largely on the location of the sampling transect (Figure 24) relative to height above the 2008 water surface elevation (Figure25) as coarser distributions trended towards lower relative heights above the channel. Also, bar surfaces coarsened toward the center of the valley, partly due to the Sandy River focusing flow into a narrow channel as it incised into the impounded sediment (Figure 26). Bar surfaces having the finest grain size were located at highest elevations above the 2008 LiDAR water surface (Figure25; Figure 26; Figure 27) and close to the valley margins. The coarser surfaces trend towards lower elevations and closer to channel center. No longitudinal trend with regard to spatial distribution of grain size within the Reservoir Reach is evident. Reservoir Reach clasts can exceed boulder size (720 mm) and likely derived from hillslopes surrounding the reservoir. The median grain-sizes for bars in this reach range from 2 to $146.9 \mathrm{~mm}$ (Figure 24; Table C1). The sand fraction was greatest, up to 86 percent, at transect A (Figure 24), a surface that was seasonally inundated during dam operations as apparent from pre-removal aerial photography. The sand content tended to be greatest at higher elevation surfaces and for early counts at repeat locations. Figure 28 shows the grain size distribution of samples collected in the reservoir. See Table C2 for grain size distributions at each sampling location. 


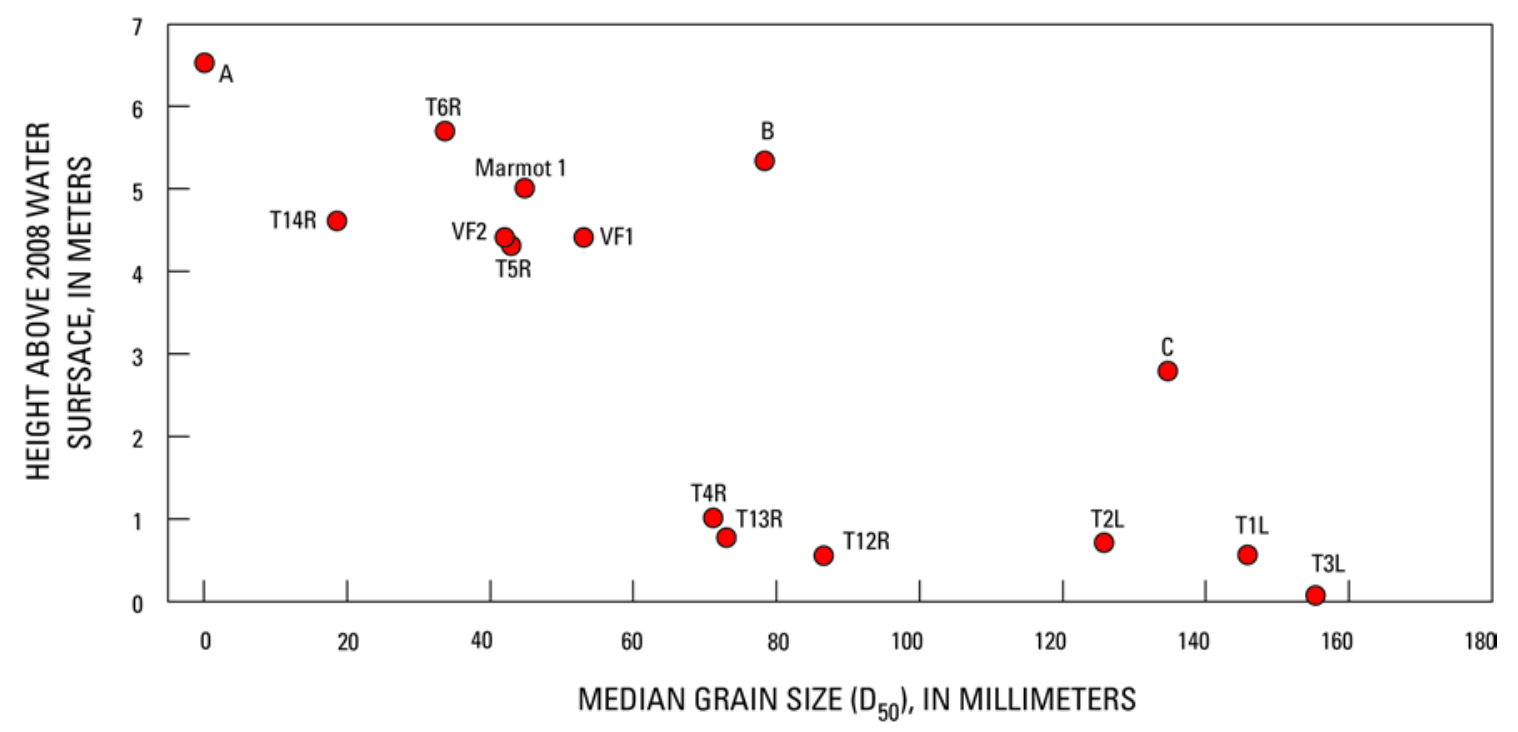

Figure 25. Median grain size of bed-material samples collected in the Reservoir Reach relative to height above the 2008 LiDAR water surface in the Reservoir Reach of the Sandy River. See appendix $C$ for sample location. 


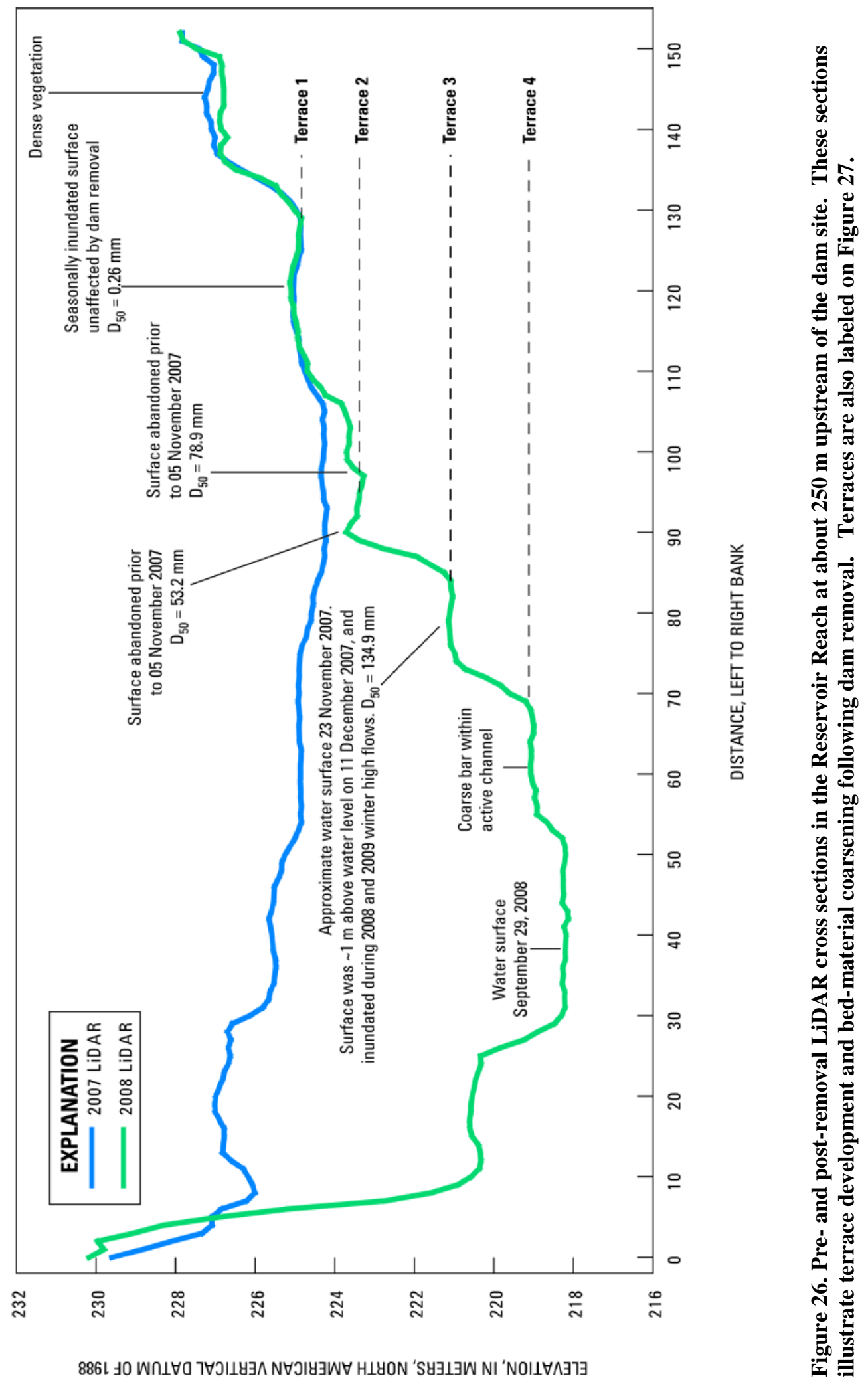




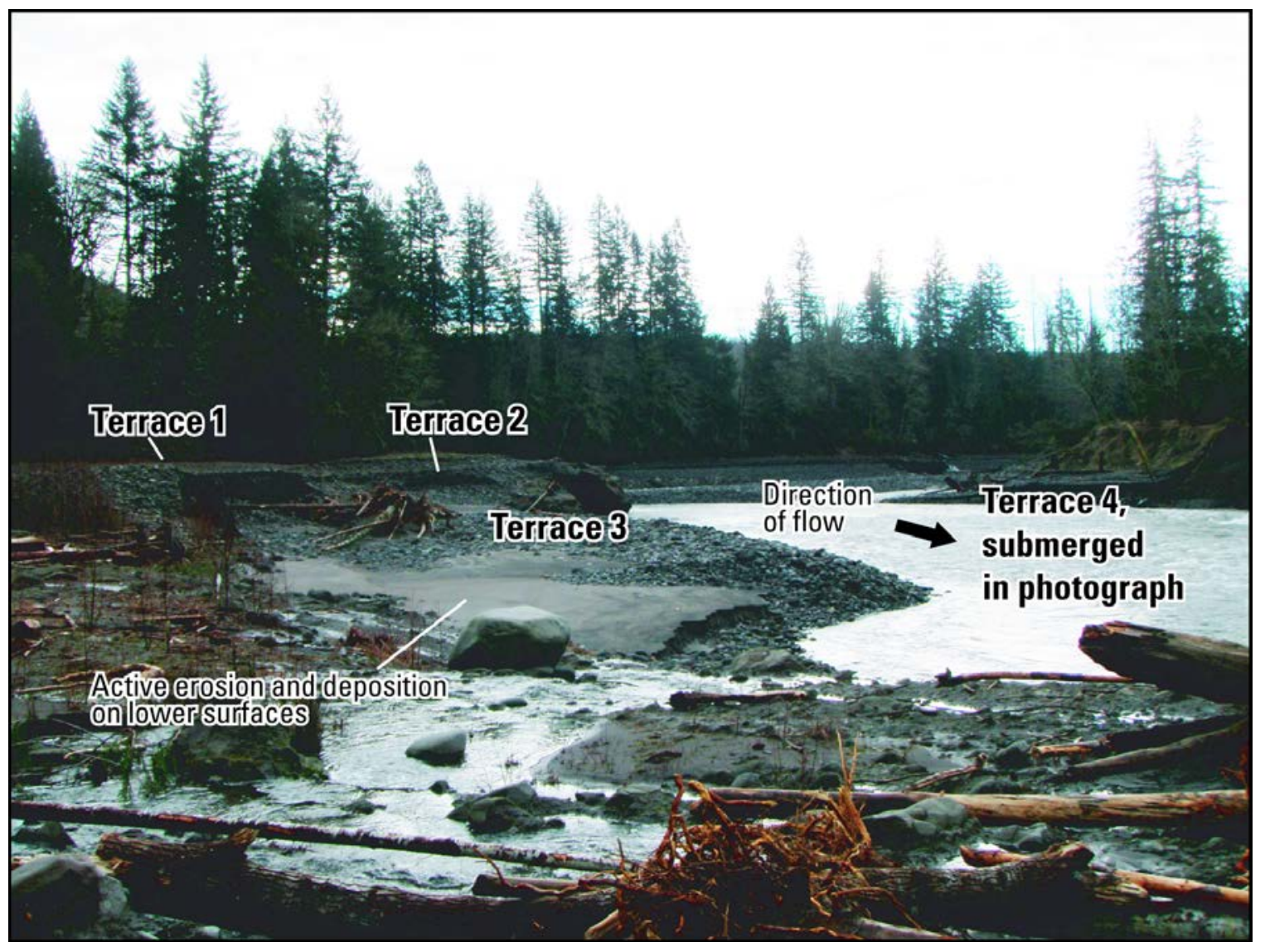

Figure 27. Photograph of bedrock and remaining sediment relative to channel position in the Reservoir Reach of the Sandy River following dam removal. Terrace locations denoted on Figure 26. 


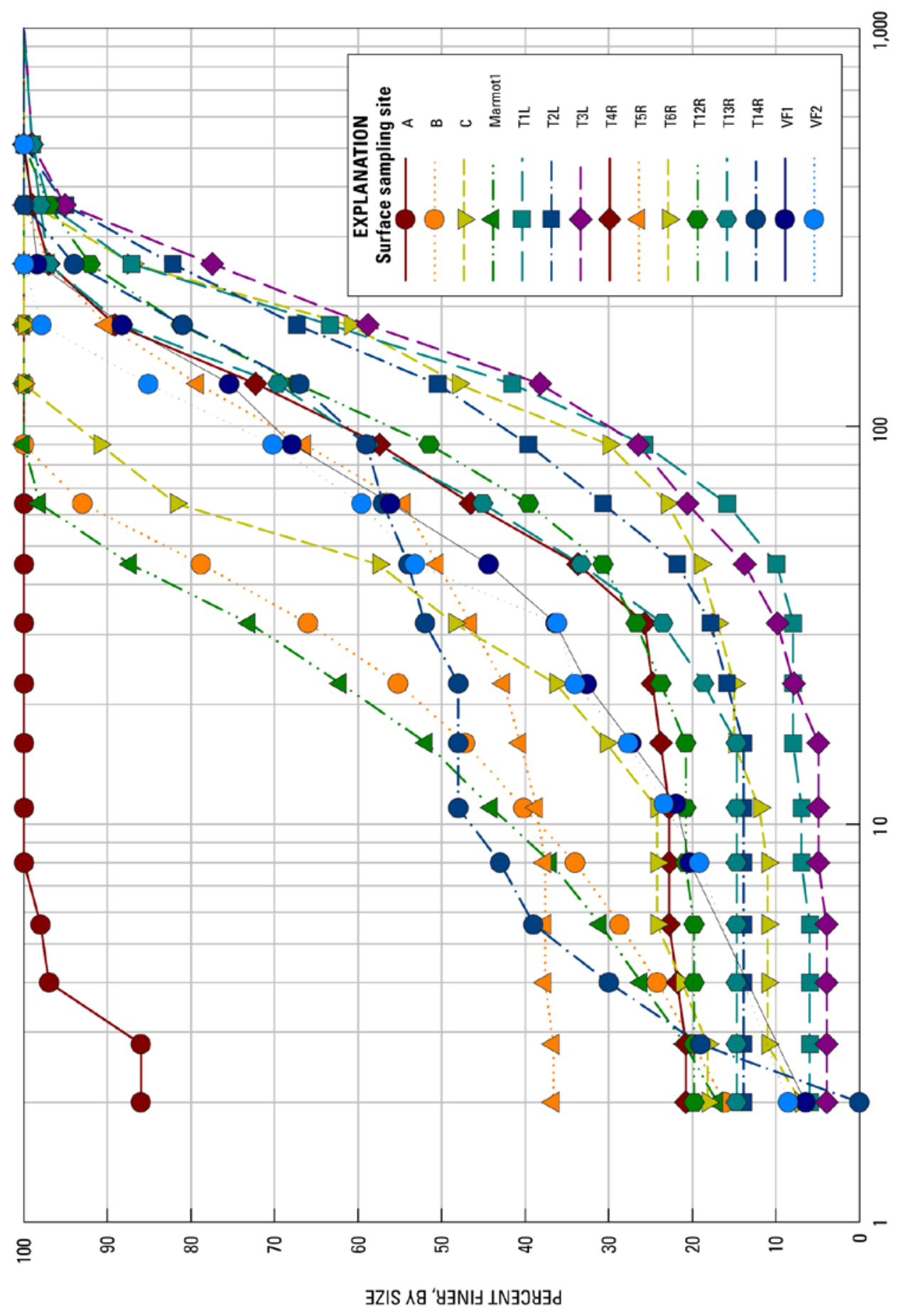


In addition to vertical changes in grain size owing to channel incision, some surfaces that were frequently inundated by flow coarsened with time. For example, at a location 250 m upstream of the dam site where a moderate vertical change in bar elevation occurred, the median grain size increased from $0.3 \mathrm{~mm}$ to $135 \mathrm{~mm}$ between 2008 and 2009.

Subsurface sampling at the upper and lower subsurface sites on terraces located $250 \mathrm{~m}$ upstream of the dam site (Figure 24) detected median grain diameters of $6.5 \mathrm{~mm}$ and $72 \mathrm{~mm}$, respectively compared to surface median diameters of $1.8 \mathrm{~mm}$ and $79 \mathrm{~mm}$, yielding armoring ratios of 0.3 and 1.1. Approximately $900 \mathrm{~m}$ upstream of the dam site, a subsurface sample had a median diameter of $55 \mathrm{~mm}$ compared to $43 \mathrm{~mm}$ on the surface and approximate armoring ratio of 0.8 . The range of armoring ratios indicates sediment transport in the Reservoir Reach probably varied as the river rapidly incised through the sediment with more transport at possible at lower armoring ratios. All armoring ratio values were less than 2.0, indicating a transport limited system (Bunte and Abt, 2001); more sediment was available than the river had capacity to transport.

Errors associated with sampling can arise from sampling technique, operator error, or a sample size that is not statistically large enough. Surface measurements are particularly subject to errors from sampling technique including using a ruler to measure the b-axis as opposed a standardized gravel template which is becomes more significant as grain size decreases. Other sampling technique errors may stem from operator bias towards selecting larger clasts which can be avoided by selecting particles spaced evenly 
along a tape measure. Small sample sizes also create error but can be avoided by increasing the number of particles measured. Subsurface measurements are subject to these same errors as well as other operator errors-spilling of fine material, and sampling technique errors-sizes of sieves used to separate grains. In this study for example, the smallest sieve size used in the 2009 subsurface samples was $8 \mathrm{~mm}$ which likely coarsely skews measurements for samples with abundant clasts smaller than $8 \mathrm{~mm}$. Larger phi sieve sizes should be used if this is the case. Additionally, the largest clast should not make up more than 1 percent of the total sample to achieve an adequate sample size (Bunte and Abt, 2001). Two subsurface samples each had a $512 \mathrm{~mm}$ clast accounting for 2 percent and 2.5 percent of the respective total sample mass, accounting for minimal error. 


\section{Chapter VII: Discussion}

Several factors dictate how a channel might respond to dam removal including: the height and width of the structure, length of time it has been in place, channel gradient, volume of sediment in storage, grain-size distribution and stratigraphy of the reservoir deposit, typical sediment transport loads, variation in discharge seasonally and annually, and reservoir morphology among others (Pizzuto, 2002). The extent of geomorphic channel change caused by the presence of the dam coupled with a variable hydrologic regime may prevent a river from fully regaining its original form following dam removal. It could possible permanently change the connectivity with the upstream and downstream reaches or how the channel interacts with the floodplain. River discharge, long term duration of high discharge and peak flows, is a driver behind the volume of sediment eroded from a reservoir impoundment. If river discharges are insufficient to transport sediment, the reach may not return to a pre-dam state. Alternatively, flows may have the capacity to transport impounded sediment, but if some of the remaining deposit is perched above an incised channel, on bedrock or in terraces or is in some way hydraulically out of reach, the initial channel state may not ensue. Factors that appeared to control the physical changes that occurred on the Sandy River following the removal of Marmot Dam include the volume and grain-size distribution of the impounded sediment, hydrologic drivers, and the inherent valley and channel morphology. In the case of Marmot Dam, moderate discharge events were observed to erode and transport large amounts of sediment. 
The techniques used to assess the initial rates of channel response to dam removal may provide tools useful for monitoring channel change following future dam removals. The response of the Sandy River channel documented here may also help refine development of conceptual and numerical models that have been used to predict channel responses to dam removals and show how quickly river systems can respond. From historical maps and descriptions, the Sandy River Reservoir Reach prior to construction of Marmot Dam in 1913 was characterized by a fast flowing river over coarse bed-material, confined by bedrock walls. A longitudinal profile from 1911 generally is steep, $0.006 \mathrm{~m} / \mathrm{m}$, through the Reservoir Reach, declines just below the dam site to $0.001 \mathrm{~m} / \mathrm{m}$, and then returns to a relatively steep gradient, $0.004 \mathrm{~m} / \mathrm{m}$, about $1 \mathrm{~km}$ downstream of the dam site. Most of the pre-dam channel elevations along the upper 0.8 $\mathrm{km}$ of the Beaver Island Reach are inferred to be higher than present, post-removal elevations by about 2 m. Differences between the 1911 and 2007 elevations may be a sign of how the Sandy River responded to dam emplacement: channel incision downstream of the dam in response to dam construction, although it is unlikely that $2 \mathrm{~m}$ of incision took place along this boulder and bedrock reach in the 95 years following dam construction. Following the completion of Marmot Dam, bed degradation just downstream of the dam site was probably less than $1 / 2 \mathrm{~m}$. It is also likely that the reservoir filled with sediment within 5 to 20 years following construction given average transport rates, and therefore, sediment passing over the dam likely would again be supplying material to the Beaver Island Reach. The base-line morphometrics, such as 
pre-dam channel elevations, widths, and gradients, provide context with which to gage the response of the Sandy River to dam removal and release of reservoir sediment. These morphometrics may provide the state toward which the Sandy River channel near the dam will evolve, because anthropogenically altered streams may shift toward natural conditions when a stressor is removed (Doyle and others, 2005).

When a dam obstructs natural stream flow, reaches upstream of the dam are subject to backwater effects and reservoir filling, which reduce channel gradient (Leopold and others, 1964; Julien, 1998). After removing a dam, a steep gradient between the sediment impounded behind the dam and the channel downstream of the dam produces a change in local base level. Channel incision and widening occur in response to the river's sudden ability to transport greater amounts of larger caliber sediment. Following dam removal, a channel will cut downward through the unconsolidated sediment deposited in the reservoir. Commonly, rapid incision narrows the channel through the deposit and is then followed by lateral erosion (Cantelli and others, 2004) as near vertical banks are vulnerable to collapse which can often be instigated by channel undercutting and is a function of grain size (Thorne, 1982, Doyle, 2003b). This is the scenario observed in the Sandy River Reservoir Reach.

The initial channel changes after breaching of Marmot Dam followed a series of rapid downcutting and widening events in conjunction with headward erosion through the impounded sediment. Time-lapse photography captured these changes in the lower Reservoir Reach. Channel widening persisted for over weeks as rapidly incised 
unconsolidated sediment became exposed and over steepened. Bank failures and channel bank erosion in the lower Reservoir Reach were the main mechanism of channel widening and were dramatic as the Sandy River responded to a sudden change in base level.

Knickpoint development and migration is typically controlled by gradient, water discharge, sediment composition, and the presence of confining bed morphology, such as bedrock walls that might confine lateral movement (Gardner, 1983; Grant and others, 2008). The channel evolved as headcutting propagated upstream; a knickpoint rapidly migrated through the unconsolidated and non-cohesive sediment (Wallick and others, 2008). The steep gradient changes over the face of the coffer dam, $0.25 \mathrm{~m} / \mathrm{m}$, also promoted initial upstream movement while bedrock topography upstream of the dam site controlled the course of the knickpoint (Grant and others, 2008).

In the weeks and months following breaching of the coffer dam, channel changes slowed. After about one year discharges greater than the 5-year-recurrence-interval flow $\left(632 \mathrm{~m}^{3} / \mathrm{s}\right)$ were necessary to substantially erode and transport sediment. Such large discharges are likely needed in the future to cause appreciable channel change as channel characteristics evolve toward pre-dam conditions (see Figure 19; Figure 21). This is to be expected; as reach gradient decreases, channel change will evolve more slowly. Bar texture and reach bed form characteristics are still evolving towards a pre-dam state while other characteristics, such as gradient, appear to be much closer to the natural channel. Longitudinal surveys show that the gradient as of $2008(0.006 \mathrm{~m} / \mathrm{m})$ approximates its pre- 
dam value $(0.006 \mathrm{~m} / \mathrm{m})$. These water-surface gradients likely are a good estimate of the reach average channel bed even though water surface data was used as a proxy for channel gradient and may not accurately portray the local variances in channel gradient. Additionally, water-surface profiles vary with river discharge which ranged from 12.8 $\mathrm{m}^{3} / \mathrm{s}$ to $81.0 \mathrm{~m}^{3} / \mathrm{s}$ during the various surveys; however, the differences in elevation induced by differences in stage are less than a couple meters and were ignored. Some confidence in this assumption is provided by the cross-sectional surveys which measured to the channel bottom and aligned with the longitudinal profiles.

Channel widths and overall morphology in the Reservoir Reach are most different from the pre-dam channel form where gravel bars have remnant terraces not present in the pre-dam configuration. The areal extent of active gravel bars increased substantially within just a few months in the Reservoir Reach following breaching of the coffer dam; however, relict surfaces of some of the formerly active bars are preserved in terraces left behind. The location of terraces largely appears to be controlled by bedrock that crops out within the channel as these terraces are perched on top of bedrock above the channel or remain protected in the wake of in-channel bedrock outcrops. These terraces may ultimately store some of the impounded sediment long term as it is elevated above heights reached by typical streamflows. Under the right circumstances, however, sufficiently high stage and stream power, greater than that of a 5-year recurrence interval flow and possibly similar to the 1964 flood-of-record, may transport some of the remaining sediment out of the Reservoir Reach. The reach will continually evolve 
whether or not all the impounded sediment has been removed but to fully return to a predam state, more of the reservoir impoundment likely will need to be eroded.

As the channel incised and widened, bed textures changed. The variation in particle size in reservoir sediment may determine where and how much sediment is transported as grain sizes coarsen and become more uniform (Leopold and others, 1964; Yang, 1996), although future sediment supply to the reach could promote coarsening or fining. Following the construction of the dam, the Reservoir Reach filled with particle sizes smaller than the estimated pre-dam distribution (Figure 6). The capacity of the Sandy River to transport material is great and the removal of sand and small gravel fraction lead to a general coarsening of the bed material. Vertical downward coarsening was observed from surficial grain size data collected after dam removal. Remaining bar surfaces having the finest grain size were located at highest elevations above the water surface and close to the valley margins. Surfaces also coarsened toward the valley center following incision of the channel through the reservoir deposit. Reservoir Reach armoring ratios were between 0.3 and 1.1 indicating the reach was transport limited (an armoring ratio near 2.0 suggests a balance between supply and transport and values greater than 2.0 suggest a supply limited setting), although, sediment transport probably varied as the river rapidly incised through the impoundment. During initial erosion through the unconsolidated sediment, the Sandy River was overloaded with sediment and it is likely relatively finer sediment was transported first followed by coarser particles. Over time, sediment transport varied with fluctuations in discharge. Additionally, as the 
river incised through the impoundment, it is likely that different grain-size populations were encountered and eventually reaching a coarse, pre-dam channel bed.

Downstream of the breached dam an aggradational wedge, 2-km-long, formed (Major and others, 2008; Major and others, in press). Composed of cobbles, gravel, and some sand, ( $\mathrm{D}_{50} \sim 45 \mathrm{~mm}$ to $111 \mathrm{~mm}$, Table C1) the wedge mantled the existing channel bed in the Beaver Island Reach, whereas the finer material was chiefly flushed to the channel edges and farther downstream. Maximum aggradation occurred just downstream of the former dam site and the wedge thinned through the Beaver Island Reach to the entrance of the Sandy River gorge. Although most of the sediment deposition occurred in the hours and days following breaching, aggradation continued as the reservoir deposit eroded through the first year following removal. Wedge volume decreased after the first year indicating the Beaver Island Reach shifted from an accumulation zone to one of transport and mild erosion.

Burroughs and others (2009) observed a general decrease in the channel width over a 10 year period following the removal of the Stronach Dam on the Pine River, Michigan. Local variation in slope and geology influenced the planform that developed, with the greatest narrowing near the dam site and decreasing in the upstream direction. In conjunction with width changes, slope through that reach increased over the same period. There were only slight increases in median grain size within the impounded sediment but significant increases in overall grain-size distributions. Comparatively on the Sandy River, the channel through the Reservoir Reach had widened after some initial 
narrowing. Similar to what was observed on the Pine River reservoir, the evolution of the Reservoir Reach was controlled largely by the local geology, and the gradient in the Sandy River Reservoir Reach increased rapidly at first, as compared with the pre-removal reach-average gradient, but then slowed (Figure 19). Several factors likely account for the differences in reservoir-reach channel evolution observed following dam removal in these two cases (Table 7), including the size of the dam as it provided a drop in base level between the upstream and downstream reaches, the type of removal, initial grain-size distribution, average annual transport, local gradients following the beginning of dam removal, and many other regional climatic and geologic conditions.

Table 7. Attributes of the Stronach Dam on the Pine River, Michigan and Marmot Dam on the Sandy River, Oregon that may explain different post-removal reservoir evolution. [Abbreviations: $\mathrm{m}$, meter; $\mathbf{m}^{3}$, cubic meter; yr, year]

\begin{tabular}{lll}
\multicolumn{1}{c}{ Attributes/Dam } & \multicolumn{1}{c}{ Stronach Dam } & Marmot Dam \\
\hline Stored sediment volume $\left(\mathrm{m}^{3}\right)$ & 789,000 & 750,000 \\
Dam height $(\mathrm{m})$ & 4.6 & 14.3 \\
Removal type & stepped over 7 years & single season \\
Dominant grain size & sand & gravel \\
Average annual transport $\left(\mathrm{m}^{3} / \mathrm{yr}\right)$ & 28,000 & 37,000 \\
Upstream gradient, pre-removal & 0.001 & 0.002 \\
Downstream gradient, pre-removal & 0.003 & 0.007 \\
\hline
\end{tabular}

Doyle and others (2003a) observed a general pattern in reservoir evolution following the removal of small dams on two rivers in Wisconsin. They observed bed degradation and channel widening to occur upstream of the dam site and channel-bed aggradation to occur downstream of the dam site. Although the dams removed in Wisconsin were smaller than Marmot Dam, the evolutionary patterns within the reservoir 
reaches behind those dams were similar to Marmot Dam. Doyle and others (2003a) observed that erosion was largely controlled by knickpoint migration rate which was measured at $10 \mathrm{~m} /$ day in the first 24 hours following the Rockdale Dam removal on the Koshkonong River. They also monitored how erosion happened much quicker in an unconsolidated reservoir impoundment compared to consolidated sediment on the Baraboo River following the removal of the La Valle Dam. At Marmot Dam, knickpoint migration was measured at rates of 480 to $4,800 \mathrm{~m} /$ day over the first few days following breaching. Several factors may explain differences in how each reservoir evolved following dam removal. The height of the Wisconsin dams, less than $3.3 \mathrm{~m}$, formed a smaller drop in base level between the upstream and downstream reaches, and removal strategies varied as the dams were dewatered or breached and the remaining structure was removed about 7 months to 1 year later. Reservoir grain-size distribution of unconsolidated sediment was likely a significant factor in the patterns of knickpoint migration, dominantly sand and finer material in the Wisconsin Rivers, versus a graveldominated reservoir deposit on the Sandy River. Local, pre-dam gradients were similar ( 0.002 to $0.005 \mathrm{~m} / \mathrm{m}$ at Marmot Dam vs. 0.002 to $0.007 \mathrm{~m} / \mathrm{m}$ at the Wisconsin dams).

Numerical modeling of the lower $1 \mathrm{~km}$ of the Marmot Dam reservoir predicted a decrease in impounded sediment thickness of 3 m, 4 m, and 5 m after 30 days, 60 days and 1 year following breaching (Stillwater Sciences, 2000a,b). Also, reach-averaged gradient was predicted to be 0.005 in the lower $1 \mathrm{~km}$ of the Reservoir Reach after one year (Stillwater Sciences, 2000a,b; Cui and Wilcox, 2008). Longitudinal profiles from 
the first two years following removal are close to the modeled outcome, as decreases of 6.8 to $7.7 \mathrm{~m}$ in deposit thickness occurred in the lower $100 \mathrm{~m}$ of the reservoir within two weeks following breach, $10 \mathrm{~m}$ after 60 days, and about $12 \mathrm{~m}$ after 1 year. This shows more rapid erosion compared to modeling results. Longitudinal water surface profiles illustrate average water surface gradients of $0.006 \mathrm{~m} / \mathrm{m}$ in the first year following the removal. The rates of actual change are more rapid than modeled which is likely due to averaging channel information over a cross-section and over time in the one-dimensional models, the uncertainty of input parameters such as grain sizes, or that models are based on theory of sediment transport processes that are not fully understood (Stillwater Sciences, 2000a,b, Cui and others, 2011).

The extent to which changes occurred in the Reservoir Reach was largely controlled by existing geomorphic and hydrologic conditions. Early erosion through the first storm season following dam removal was dependent chiefly on the abundance of unconsolidated sediment responding to a sudden change in base level and less dependent on river discharge. However, timing of erosion and significant changes in the second year following removal mimics variations in the hydrograph. Although relatively larger discharge events were observed in the second year following removal than the first, second year erosion volumes are much smaller than initial erosion amounts. Reservoir erosion was driven by discharge so when discharge increased, the relative amount of erosion associated with a storm event increased. Locations of gravel bars do not differ appreciably between the pre-dam, dam-era, and post-dam channel forms in this reach. 
Valley morphology and channel hydraulics appear to be driving the resting location for these features. Additionally, bedrock terraces and walls have driven post-removal placement of gravel, laterally and stratigraphically as observed with many gravel bars.

Channel evolution within the Reservoir Reach followed prior conceptual models of river response to dam removal (for example Doyle and others, 2003b) in that the channel incised and widened through the impounded deposit and grain sizes coarsened with time. Additionally, the majority of changes that occurred did so soon after the breaching process and slowed with time. However, comparisons to other documented dam removals and modeled predictions show the rates of channel change on the Sandy River occurred much quicker than expected.

The large volume of sediment retained by Marmot Dam, remaining distribution of Reservoir Reach deposits, and channel geometry, including bedrock topography and bar locations, are factors that may prevent post-removal evolution of the Sandy River from fully achieving its pre-dam morphology. Also, future river discharges will dictate when and where quasi-equilibrium channel occurs. As some of the remaining reservoir deposit is stored in terraces and above the channel or sheltered in the wake of in-channel bedrock, this sediment is out of reach under normal flow conditions. River flows must become sufficiently large to reach higher elevation sediment for erosion to take place; otherwise, the remaining sediment will likely remain in place and the channel will not revert to its exact pre-dam state. 
A broader characterization of changes in the Reservoir Reach over many years could potentially be useful in the overall understanding the effects of a large dam removal. Ongoing research on how the Sandy River is physically adjusting to the removal of Marmot Dam includes monitoring by PGE as part of the FERC decommissioning settlement agreement, probable annual topographic survey collection by the USGS, and research on the downstream response by Johns Hopkins University. Other interest groups, researchers, and stakeholders also continue to monitor biologic, economic, and social impacts of decommissioning the Bull Run Hydroelectric Project. A more in-depth analysis of channel morphology from aerial photography and LiDAR, including future acquisitions, would likely be beneficial to the ongoing studies concerning geomorphic change at Marmot Dam and for dam removal in general. More grain-size data collection over a broader spatial extent could provide a linkage between the connection upstream and downstream of the dam site. Additional grain-size could possibly be used to infer information about sediment transport conditions over time following the removal.

The techniques used to monitor the geomorphic evolution of the Reservoir Reach were adequate at the time most of this thesis research was being completed. Future dam removal investigations, on the Sandy River and for other dam removals, could follow the same basic methodology but would likely benefit from slight adjustments to the methods presented in this research. Additionally, newer software and techniques are now available. For example, the combination of time-lapse photography and photogrammetry 
software is an effective tool to measure geomorphic change, especially at small time intervals where repeat ground or airborne surveys are not feasible. While a minimum of three photograph vantage points were needed to construct a three-dimensional model, more photographs with more overlap appeared to produce better models. Also, the cameras used in this study only recorded change in the lower $100 \mathrm{~m}$ of the Reservoir Reach. More spatial coverage of the reservoir with time-lapse cameras to capture change farther upstream would have been helpful in more fully explaining initial processes throughout reservoir; although, this would have required more cameras. Newer photogrammetric software that can automatically match points between the photographs would reduce the time necessary to process three-dimensional models and probably provide a denser point distribution of the reservoir models which could be used to generate digital terrain models. Additionally, new techniques such as terrestrial laser scanning are becoming more economically viable. This could be used to replace fieldbased topographic surveys, saving time and providing a more robust density on surface information to create surfaces. 


\section{Chapter VIII: Conclusions}

Overall, my findings indicate valley morphology and local in-channel bedrock topography controlled the spatial distribution of post-dam reservoir sediment while variability in river discharge determined the timing of episodic sediment release. The timing and intensity of flow events are in part responsible for the rapid changes within the Reservoir Reach shortly after dam removal and subsequent slowing of change. Longitudinal and stratigraphic spatial variations of grain-size distributions of the impoundment and remaining bar and terrace formations, as well as pre-dam topography and existing valley morphology, affected rates of reservoir evolution.

Reconstruction of pre-dam conditions, derived from qualitative descriptions of the pre-dam channel and historical channel maps, indicate that the Reservoir Reach was characterized by a steep, energetic mountain river. Starting in 1913 and for the next 94 years, the Marmot Dam altered the natural river processes such that sediment impounded behind the dam. In 2007, the dam was breached and I monitored reservoir response. Over the hours and days following breaching of the coffer dam, photographic monitoring indicates a rapid drop in the elevation of the channel bed in the Reservoir Reach at a rate of up to $12.6 \mathrm{~m} / \mathrm{hr}$ as the river incised through the unconsolidated deposit. Channel widening closely followed rapid incision in the first hours following removal at rates up to $26.3 \mathrm{~m} / \mathrm{hr}$. With time, the rates of channel adjustment decreased, with significant changes in horizontal and vertical channel patterns requiring greater catalysts, such as increases in discharge, to facilitate further channel alteration. 
Reservoir bar and terrace morphology and grain-size distributions reflect changing base-level conditions over time through an increase in the number of reservoir surfaces and coarsening of sediment. Complex bar and terrace surfaces developed as the Sandy River episodically cut through and migrated within the reservoir. Median grain sizes on these surfaces follow an increasing trend with decreasing vertical proximity towards the water-surface level. Additionally, repeat measurements of grain size at the same location over time show coarsening. After two years, coarse sediment of the original pre-dam channel bed was likely exhumed and intermixed with the remaining reservoir deposit as sediment as flows continued to mobilize impounded sediment in the reach.

The volume of sediment eroded from the Reservoir Reach was estimated to be about 125,000 $\mathrm{m}^{3}$ within the first two weeks following breach. Large volumes of sediment continued to erode through the first year following removal, although these volumes were decreasing with time as evidenced by event-based Reservoir Reach surveys. By the end of the first year, 50 percent of the $730,000 \mathrm{~m}^{3}$ deposit had been eroded.

Comparison of the channel changes that occurred following dam removal with the Sandy River's pre-dam form indicate that channel gradient, width, and planform are approaching a quasi-equilibrium state. A comparison of geomorphic predictions based on pre-removal numerical modeling with actual outcomes shows that modeling was an efficient means of assessing possible outcomes. However, site-specific research on 
future dam removals may be needed to refine predictive capabilities. As the channel continues to stabilize and the evacuation of the impoundment from and the location of remaining in the reservoir has a waning effect on channel form in the study area, it is difficult to tell how this area will respond. 


\section{Works Cited}

American Rivers and Trout Unlimited, 2002, Exploring dam removal, A decision making guide: American Rivers and Trout Unlimited, 85 p.

http://act.americanrivers.org/site/DocServer/Exploring_Dam_Removal-A_DecisionMaking_Guide.pdf?docID=3641

Aspen Institute, 2000, Dam removal, A new option for a new century: Queenstown, Maryland, The Aspen Institute, 81 p. http://www.aspeninstitute.org/publications

Barnes, F.F. and Butler, J.W., Jr., 1930, The structure and stratigraphy of the Columbia River Gorge and Cascade Mountain in the vicinity of Mount Hood: University of Oregon, Eugene, Oregon, M.A. Thesis, 156 p., 5 sheets.

Bauer, T.R., 2009, Profile of the Sandy River for Marmot Dam Removal: U.S. Bureau of Reclamation, Technical Service Center, Sedimentation and River Hydraulics Group, 8668240, SRH-2009-44, 20 p.

Brummer, C.J. and Montgomery, D.R., 2006, Influence of coarse lag formation on the mechanics of sediment pulse dispersion in a mountain stream, Squire Creek, North Cascades, Washington, United States: Water Resources Research, v. 42, 16 p., W07412, doi:10.1029/2005WR004776.

Bunte, Kristin and Abt, S.R., 2001, Sampling surface and subsurface particle-size distributions in wadable gravel and cobble-bed streams for analyses in sediment transport, hydraulics, and stream-bed monitoring: U.S. Department of Agriculture, Forest Service, Rocky Mountain Research Station, General Technical Report RMRS-GTR-74, $428 \mathrm{p}$.

Bureau of Land Management (BLM), 2009, Land Status and Cadastral Records Viewer, Willamette Meridian-Oregon and Washington States: U.S. Department of the Interior, Bureau of Land Management, accessed 2009 at http://www.blm.gov/or/landrecords/survey/ySrvy1.php.

Burnett, J., 1860, Field survey notes, Survey of the east boundary of Township 2 South, Range 5 East: Bureau of Land Management, Oregon State Office, Land Status and Cadastral Survey Records, Willamette Meridian-Oregon and Washington, v. OR R0064, survey p. 0237.0-0244.0, http://www.blm.gov/or/landrecords/survey/ySrvy1.php.

Burroughs, B.A., Hayes, D.B., Klomp, K.D., Hansen, J.F., and Mistak, Jessica, 2009, Effects of Stronach Dam removal on fluvial geomorphology in the Pine River, Michigan, United States: Geomorphology, v. 110, p. 96-107. 
Cameron, K.A. and Pringle, P.T., 1986, Post-glacial lahars of the Sandy River basin, Mount Hood, Oregon: Northwest Science, v. 60, p. 225-237.

Cameron, K.A. and Pringle, P.T., 1987, A detailed chronology of the most recent major eruptive period at Mount Hood, Oregon: Geological Society of America Bulletin, v. 99, p. 845-851. doi: 10.1130/0016-7606(1987)99<845:ADCOTM>2.0.CO;2

Cantelli, Alessandro, Paola, Chris, and Parker, Gary, 2004, Experiments on upstreammigrating erosional narrowing and widening of an incisional channel caused by dam removal: Water Resources Research, v. 40, 12 p., doi:10.1029/2003WR002940

Charlton, Ro, 2008, Fundamentals of Fluvial Geomorphology: New York, Routledge, $234 \mathrm{p}$.

Cooper, R.M., 2005, Estimation of peak discharges for rural, unregulated streams in Western Oregon: U.S. Geological Survey Scientific Investigations Report 2005-5116, $134 \mathrm{p}$.

Crandell, D.R., 1980, Recent eruptive history of Mount Hood, Oregon, and potential hazards from future eruptions: U.S. Geological Survey Bulletin 1492, 91 p.

Cui, Yantao, Dusterhoff, S.R., Wooster, J.K., and Downs, P.W., 2011, Practical considerations for modeling sediment transport dynamics in rivers in American Geophysical Union, ed., Stream Restoration in Dynamic Fluvial Systems: Scientific Approaches, Analyses, and Tools: American Geophysical Union, Geophysical Monograph Series 194, p. 503-527.

Cui, Yantao and Wilcox, Andrew, 2008, Development and application of numerical modeling of sediment transport associated with dam removal, in Garcia, M.H., ed., Sedimentation engineering: processes, measurements, modeling, and practice: American Society of Civil Engineers, Reston, Virginia, American Society of Civil Engineers Manual 110, p. 995-1020.

David Evans and Associates (DEA), 2005, Cross-section surveys of the Sandy River: prepared by David Evans and Associates for Portland General Electric, Portland, Oregon, digital data.

David Evans and Associates (DEA), 2006, Cross-section surveys of the Sandy River: prepared by David Evans and Associates for Portland General Electric, Portland, Oregon, digital data. 
David Evans and Associates (DEA), 2007, Cross-section surveys of the Sandy River: prepared by David Evans and Associates for Portland General Electric, Portland, Oregon, digital data.

David Evans and Associates (DEA), 2008, Cross-section surveys of the Sandy River: prepared by David Evans and Associates for Portland General Electric, Portland, Oregon, digital data.

David Evans and Associates (DEA), 2009, Cross-section surveys of the Sandy River: prepared by David Evans and Associates for Portland General Electric, Portland, Oregon, digital data.

David Evans and Associates (DEA), 2010, Cross-section surveys of the Sandy River: prepared by David Evans and Associates for Portland General Electric, Portland, Oregon, digital data.

Doyle, M.W., Stanley, E.H., and Harbor, J.M., 2002, Geomorphic analogies for assessing probable channel response to dam removal: Journal of the American Water Resources Association, v. 38, no. 6, p. 1567-1579.

Doyle, M.W., Stanley, E.H., and Harbor, J.M., 2003a, Channel adjustment following two dam removals in Wisconsin: Water Resources Research, v. 39, no. 1, p. 15, doi:10.1029/2002WR001714

Doyle, M.W., Stanley, E.H., Luebke, M.A., and Harbor, J.M., 2000, Dam removal: Physical, biological, and societal considerations: American Society of Civil Engineers Joint Conference on Water Resource Engineering and Water Resources Planning and Management, Minneapolis, Minnesota, July 30-August 2, 2000.

Doyle, M.W., Stanley, E.H., Orr, C.H., Selle, A.R., and Harbor, J.M., 2005, Response of stream ecosystems to dam removal: Lessons from the heartland: Geomorphology, v. 71, p. 227-244.

Doyle, M.W., Stanley, E.H., Selle, A.R., Stofleth, J.M., and Harbor, J.M., 2003b, Predicting the depths of erosion in reservoirs following dam removal using bank stability analysis: International Journal of Sediment Research, v. 18, no. 2, p. 115-121.

EBASCO, 1989, Marmot Dam Rehabilitation, Design Report for Portland General Electric Company: EBASCO Services Incorporated, various pagination.

EOS, System Inc., 2004, PhotoModeler User Manual: EOS, System Inc., various pagination. 
Esler, John, 2009, Going, going, gone: Reflections on the retirement of the Bull Run Hydroelectric Project: Open Spaces, v. 9, no. 4, p. 21-25.

Federal Energy Regulatory Commission (FERC), 2003, Final Environmental Impact Statement, Bull Run Hydroelectric Project (FERC Project No. 477-024)--Oregon: Federal Energy Regulatory Commission, Office of Energy Projects, Washington, D.C., 289 p.

Gardner, T.W., 1983, Experimental study of knickpoint and longitudinal profile evolution in cohesive, homogeneous material: Geological Society of America Bulletin, v. 94, p. 664-672.

Graf, W.L., 1999, Dam nation: A geographic census of American dams and their largescale hydrologic impacts: Water Resources Research, v. 35, no. 4, p. 1305-1311.

Graf, W.L., ed., 2003, Dam Removal Research, Status and Prospects, Proceedings of The Heinz Center's Dam Removal Research Workshop, October 23-24, 2002: Washington, D.C., The H. John Heinz III Center for Science, Economics and the Environment, 165 p.

Graf, W.L., 2005, Geomorphology and American dams: The scientific, social, and economic context: Geomorphology, v. 71, p. 3-26.

Gran, K.B. and Montgomery, D.R., 2005, Spatial and temporal patterns in fluvial recovery following volcanic eruptions: Channel response to basin-wide sediment loading at Mount Pinatubo, Philippines: Geological Society of America Bulletin, v. 117(1-2), p. 195-211. doi:10.1130/B25528.1

Grant, G.E., Marr, J.D., Hill, C., Johnson, S., Campbell, K., Mosheni, O., Wallick, J.R., Lewis, S.L., O'Connor, J.E., Major, J.J., and Burkholder, B.K., 2008, Experimental and field observations of breach dynamics accompanying erosion of Marmot cofferdam, Sandy River, Oregon, in Babcock, R.W. and Walton, R., eds., American Society of Civil Engineers Proceedings of the 2008 World Environmental and Water Resources Congress, Honolulu, Hawaii, May 12-16, 2008, 10 p.

Grant, G.E., Schmidt, J.C., Lewis, S.L., 2003, A geologic framework for the interpreting downstream effects of dams on rivers: Water Science and Application, v. 7, p. 209-225.

Heinz Center, 2002, Dam Removal, Science and decision making: Washington, D.C., The H. John Heinz III Center for Science, Economics and the Environment, 236 p. 
Hoffman, D.F. and Gabet, E.J, 2007, Effects of sediment pulses on channel morphology in a gravel-bed river: Geological Society of America Bulletin, v. 119, no. 1, p. 116-125.

Julien, P.Y., 1998, Erosion and Sedimentation: Cambridge University Press, New York, New York, 280 p.

Keith, M.K., Wallick, J.R., Major, J.J., O'Connor, J.E., Spicer, K.R., and Rhode, Abigail., 2009, Comparison of pre- and post-dam attributes of the reservoir reach of the Sandy River following removal of Oregon's Marmot Dam: Geological Society of America Abstracts with Programs, Annual Meeting, Portland, Oregon, v. 41, no. 7, p. 132, abstract $38-4$.

Kondolf, G.M., Lisle, T.E., Wolman, G.M., 2003, Bed sediment measurement in Kondolf, G.M. and Piegay, Herve, eds., Tools in Fluvial Geomorphology: John Wiley and Sons, Chichester, England, p. 347-396.

Lancaster, S.T., Underwood, E.F., and Frueh, W.T., 2010, Sediment reservoirs at mountain stream confluences: Dynamics and effects of tributaries dominated by debrisflow and fluvial process: Geological Society of America Bulletin, v. 122, no. 11/12, p. 1775-1786.

Leopold, L.B., 1970, An improved method for size distribution of stream bed gravel: Water Resources Research, v. 6, no. 5, p. 1357-1366.

Leopold, L.B., Wolman, M.G., and Miller, J.P., 1964, Fluvial Processes in Geomorphology: Dover Publications, INC., New York, 522 p.

Madej, Mary Ann, and Ozaki, Vicki, 1996, Channel response to sediment wave propagation and movement, Redwood Creek, California, USA: Earth Surface Processes and Landforms, v. 21, p. 911-927.

Major, J.J., Dzurisin, Dan, Schilling, S.P., and Poland, M.P., 2009, Monitoring lava-dome growth during the 2004-2008 Mount St. Helens, Washington eruption using oblique terrestrial photography: Earth and Planetary Science Letters, v. 286, p. 243-254.

Major, J.J., Janda, R.J., and Daag, A.S., 1996, Watershed disturbance and lahars on the east side of Mount Pinatubo during the mid-June 1991 eruptions, in Newhall, C.G. and Punongbayan, R.S., eds., Fire and Mud: Eruptions and lahars on Mount Pinatubo, Philippines: Seattle, University of Washington Press, p. 895-919. 
Major, J.J., O'Connor, J.E., Podolak, C.J., Keith, M.K., Spicer, K.R., Pittman, Smokey, Bragg, H.M., Wallick, J.R., Rhode, Abigail, Wilcock, P.R., Grant, G.E., in press, Geomorphic response of the Sandy River, Oregon, to removal of Marmot Dam: U.S. Geological Survey Professional Paper.

Major, J.J., O'Connor, J.E., Grant, G.E., Spicer, K.R., Bragg, H.M., Rhode, A., Tanner, D.Q., Anderson, C.W., and Wallick, J.R., 2008, Initial Fluvial Response to the Removal of Oregon's Marmot Dam: EOS Transactions of the American Geophysical Union, v. 89, no. 27, p. 241-252.

Major, J.J., O’Connor, J.E., Podolack, C.J., Keith, M.K., Spicer, K.R., Wallick, J.R., Bragg, H.M., Pittman, Smokey, Wilcock, P.R., Rhode, Abagail, Grant, G.E., 2010a, Evolving fluvial response of the Sandy River, Oregon, following removal of Marmot Dam: proceedings of the $2^{\text {nd }}$ Joint Federal Interagency Conference, Las Vegas, Nevada, June 27-July 1, 2010.

Major, J.J., Schilling, S.P., Pullinger, C.R., and Escobar, C.D., 2004, Debris-flow hazard at San Salvador, San Vicente, and San Miguel volcanoes, El Salvador: Geological Society of America Special Papers, v. 375, p. 89-109.

Major, J.J., Spicer, K.R., and Collins, R.A., 2010b, Time-lapse imagery of the breaching of Marmot Dam, Oregon, and subsequent erosion of sediment by the Sandy River, October 2007 to May 2008: U.S. Geological Survey Data Series 521, 5 p. Available at http://pubs.usgs.gov/ds/521/

Marr, J.D.G., Hill, C., Johnson, S., Grant, G., Campbell, K., Mohseni, O, 2007, Physical model study of Marmot Dam removal: Cofferdam notch location and resulting fluvial responses: prepared for Portland General Electric, Portland, Oregon, 20p.

McCammon, Bruce, 2009, Marmot and Little Sandy Dam removal, Final report: prepared by Bruce McCammon Photography for the U.S. Department of Agriculture Forest Service, Mount Hood National Forest, 34 p.

Moore-Cooks, Kimber, 2009, Accuracy Assessment of LiDAR Data: Intern project report prepared for National Center for Earth Dynamics and Johns Hopkins University, 9 p. Available at http://www.jhu.edu/marmot/.

Mount Hood National Forest, 1996, Chapter 4-Current conditions and trends in Upper Sandy Watershed Analysis: U.S. Department of Agriculture, Forest Service, Northwest Region, p 4.1-4.268. 
National Oceanic and Atmospheric Administration (NOAA), 2010, Datums and transformations: Office of Coast Survey, NOAA, accessed March 2010 at http://www.nauticalcharts.noaa.gov/csdl/learn_datum.html.

O'Connor, J.E., Major, J.J., and Grant, G.E., 2008, Down with the dams: Unchaining U.S. Rivers: Geotimes, available online at: http://www.geotimes.org/mar08/article.html?id=feature_dams.html.

Oregon Geospatial Enterprise Office, 2009, GEO spatial data library: Oregon Geospatial Enterprise Office, Oregon.gov, accessed 2009 at http://oregon.gov/DAS/EISPD/GEO/alphalist.shtml.

Orr, E.L. and Orr, W.N., 2000, Geology of Oregon, fifth edition: Dubuque, Iowa, Kendall/Hunt Publishing Company, 254 p.

Pierson, T.C., Pringle, P.T., and Cameron, K.A., 2011, Magnitude and timing of downstream channel aggradation and degradation in response to a dome-building eruption at Mount Hood, Oregon: Geological Society of America Bulletin, v. 123, no. 1/2, p. 3-20. doi: 10.1130/B30127.1

Pierson, T.C., Scott, W.E., Vallance, J.W., and Pringle, P.T., 2009, Eruption-related lahars and sedimentation response downstream of Mount Hood: Field Guide to volcaniclastic deposits along the Sandy River, Oregon in O’Connor, J.E., Dorsey, J.D., and Madin, I.P., eds., Volcanoes to Vineyards, Geologic Field Trips through the Dynamic Landscape of the Pacific Northwest: Geological Society of America, Boulder, Colorado, Field Guide 15, p. 221-236.

Pirot, Rachel, 2009, Initiation zone characterization of debris flows in November, 2006, Mount Hood, Oregon: Portland State University, Portland, Oregon, M.S. thesis, 180 p.

Pittman, Smokey and Matthews, Graham, 2008, Sandy River sediment monitoring project, Clackamas County, Oregon, WY2008 Annual Report: prepared by Graham Matthews and Associates, Weaverville, California for Sandy River Basin Watershed Council, Sandy, Oregon, 114 p.

Pizzuto, J.E., 2002, Effects of dam removal on river form and process: BioScience, v. 52, p. 683-691.

Poff, N.L. and Hart, D.D., 2002, How dams vary and why it matters for the emerging science of dam removal: BioScience, v. 52, p. 659-668. 
Pohl, M.M., 2003, American dam removal census: Available data and data needs, in Graf, W.L., ed., 2003, Dam Removal Research, Status and prospects, Proceedings of The Heinz Center's Dam Removal Research Workshop, October 23-24, 2002: Washington, D.C., The H. John Heinz III Center for Science, Economics and the Environment, 165 p.

Portland General Electric (PGE), 1911,Topographic map of Big Sandy dam construction plans: Prepared by J.G. White Engineering Corporation (inferred) for Mount Hood Railway and Power Company in Portland General Electric map archives.

Portland General Electric (PGE), 1999, Scoping document 2 for the Bull Run Hydroelectric Project, FERC Project No. 477: Portland General Electric, Portland, Oregon, and Federal Energy Regulatory Commission, Washington, D.C., 53 p.

Portland General Electric (PGE), 2002, Decommissioning plan for the Bull Run Hydroelectric Project, FERC Project No. 477: Prepared by Portland General Electric Company, Portland, Oregon for Federal Energy Regulatory Commission, Office of Hydropower Licensing, Washington, D.C., 52 p.

PRISM, 2009, PRISM Climate Group webpage: Oregon State University, Corvallis, Oregon, accessed 2009 at http:// www.prism.oregonstate.edu/

Rodolf, F., 1918, Field survey notes, Resurvey of the east boundary of Township 2 South, Range 5 East: Bureau of Land Management, Oregon State Office, Land Status and Cadastral Survey Records, Willamette Meridian-Oregon and Washington, v. OR R0064, survey p. 0632.0-0634.0, http://www.blm.gov/or/landrecords/survey/ySrvy1.php.

Scott, W.E., Pierson, T.C., Schilling, S.P., Costa, J.E., Gardner, C.A., Vallance, J.W., and Major, J.J., 1997, Volcano hazards in the Mount Hood region, Oregon: U.S. Geological Survey Open-file report 97-98, 14 p.

Simon, Andrew, 1999, Channel and drainage basin response of the Toutle River System in U.S. Geological Survey Open File Report 96-633, 130 p.

Squier Associates, 2000, Sandy River sediment study, Bull Run Hydroelectric Project (FERC Project No. 477): Prepared by Squier Associates for Portland General Electric, various pagination.

Stewart, Greg, 2006. Patterns and processes of sediment transport following sedimentfilled dam removal in gravel bed rivers: Oregon State University, Corvallis, Oregon, Ph.D. dissertation, 100 p., 43 fig. 
Stewart, Greg and Grant, G.E., 2005, Potential Geomorphic and Ecological Impacts of Marmot Dam Removal, Sandy River, Oregon: prepared for Portland General Electric, Portland, Oregon, 70 p.

Stillwater Sciences, 2000a, Evaluation of geomorphic effects of removal of Marmot and Little Sandy dams and potential impacts on anadromous salmonids: prepared by Stillwater Sciences, Berkeley, California for Portland General Electric, Portland, Oregon, $113 \mathrm{p}$.

Stillwater Sciences, 2000b, Numerical modeling of sediment transport in the Sandy River, OR following removal of Marmot Dam, Technical report: prepared by Stillwater Sciences, Berkeley, California for Portland General Electric, Portland, Oregon, 86 p.

Sutherland, D.G., Ball, M.H., Hilton, S.J., and Lisle, T.E., 2002, Evolution of a landslideinduced sediment wave in the Navarro River, California: Geological Society of America Bulletin, v. 114, no. 8, p. 1036-1048.

Taylor, Barbara, 1998, Salmon and steelhead runs and related events of the Sandy River basin-A historical perspective: prepared by Taylor, Barbara, independent consultant for Portland General Electric, Portland, Oregon, 55 p.

Thouret, J.C., 2005, The stratigraphy, depositional processes, and environment of the late Pleistocene Pollalie-period deposits at Mount Hood Volcano, Oregon, USA:

Geomorphology, v. 70, p. 12-32, doi:10.1016/j.geomorph.2005.03.008

Thorne, C.R., 1982, Processes and mechanisms of river bank erosion in Hey, R.D., Bathurst, J.C., and Thorne, C.R., eds., Gravel Bed Rivers, John Wiley, Chichester, United Kingdom, p. 227-272.

U.S. Army Corps of Engineers (USACE), 2009, CorpsMap National Inventory of Dams: U.S. Army Corp of Engineers, accessed 2010 at

http://geo.usace.army.mil/pgis/f?p=397:1:271260428131674

U.S. Geological Survey (USGS), 1914, Profile Surveys in Hood and Sandy River Basins, Oregon: U.S. Geological Survey Water Supply Paper 348, 8 p., 2 plates.

U.S. Geological Survey (USGS), 2009a, Dam Removal and Sediment Transport in the Sandy River Basin, Oregon website: Tanner, D.Q., U.S. Geological Survey, accessed 2009 at http://or.water.usgs.gov/projs_dir/marmot/index.html

U.S. Geological Survey (USGS), 2009b, National Water Information System: U.S. Geological Survey, accessed 2009 at http://waterdata.usgs.gov/nwi 
Wallick, J.R., Major, J.J., Spicer, K.R., Rhode, A., Keith, M.K., O'Connor, J.E., Burkholder, B.K., Grant, G.E., Tanner, D.Q., and Saunders, D., 2008, Erosion and redeposition of reservoir sediment in response to removal of Marmot Dam, Sandy River, Oregon: EOS, Transactions of the American Geophysical Union, v. 89, no. 53, abstract H42B-0995.

Watershed Sciences, 2006, LiDAR Remote Sensing Data Collection: Sandy River, Oregon: prepared by Watershed Sciences, Portland, Oregon for Portland General Electric, Portland, Oregon, 27 p. and digital data.

Watershed Sciences, 2008, LiDAR Remote Sensing Data Collection, Sandy River, Oregon. Final report submitted to Department of Geology and Mineral Industries, Oregon Department of Forestry, and Puget Sound LiDAR Consortium, digital data.

Watershed Sciences, 2009, LiDAR and true-color orthophotographs, airborne data acquisition and processing: Sandy River, Oregon: prepared by Watershed Sciences, Corvallis, Oregon for Grant, Gordon, U.S. Forest Service, Corvallis, Oregon, 31 p. and digital data.

Wentworth, C.K., 1922, A scale of grade and class terms for clastic sediments: The Journal of Geology, v. 30, no. 5, p. 377-392.

Wheaton, J.M., Brasington, James, Darby, S.E., and Sear, D.A., 2010, Accounting for uncertainty in DEMs from repeat topographic surveys: improved sediment budgets: Earth Surface Processes and Landforms, v. 35, p. 136-156. doi: 10.1002/esp.1886

Wise, W.S., 1969, Geology and petrology of the Mount Hood area: a study of High Cascade volcanism: Geological Society of America Bulletin, v. 80, no. 6, p. 969-1006.

Withrow-Robinson, Johannah, 2007, Erosion of reservoir sediment following the removal of the Marmot Dam, Sandy, River, Oregon: Whitman College, undergraduate thesis, 45 p. available at http://www.sandyriverpartners.org/reports/WinthRobinthesis \%20final.pdf?PHPSESSID=481e5de9739298cece7d26bae435d1c2

Wolman, M.G., 1954, A method of sampling coarse river-bed material: Transactions, American Geophysical Union, v. 35, no. 6, p. 951-956.

Yang, C.T., 1996, Sediment Transport, Theory and Practice: Malabar, Florida, Krieger Publishing Company, 396 p. 
Zilkoski, D.B., Richards, J.H., and Young, G.M., 1992, Special Report: Results of the general adjustment of the North American Vertical Datum of 1988: Surveying and Land Information Systems, v. 52, no. 3, p. 133-149. 
Appendix A. Resources and links to other Marmot Dam related studies. 


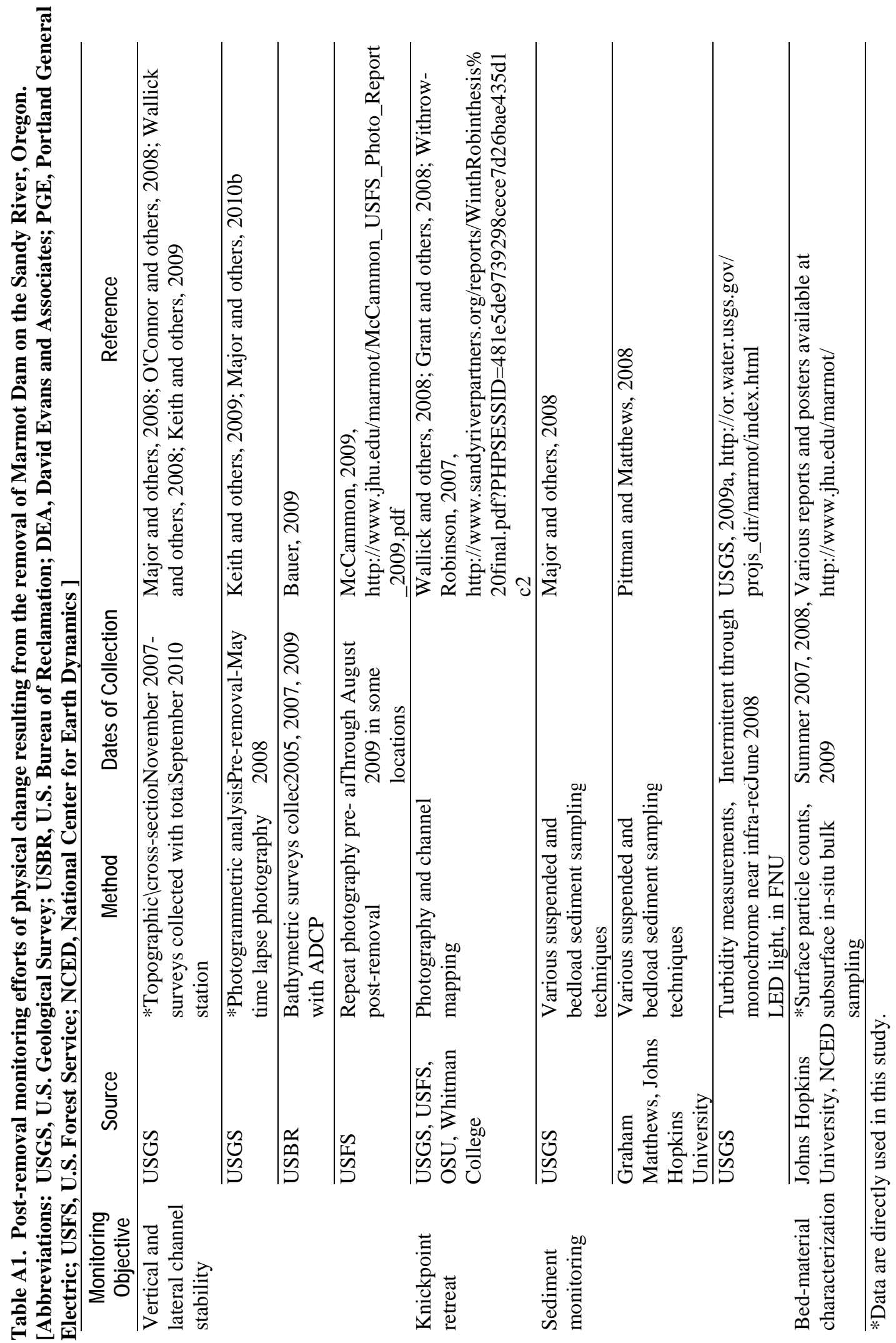


Appendix B. Photogrammetry model results obtained with PhotoModeler and repeat time lapse photography of the Marmot Dam reservoir. 


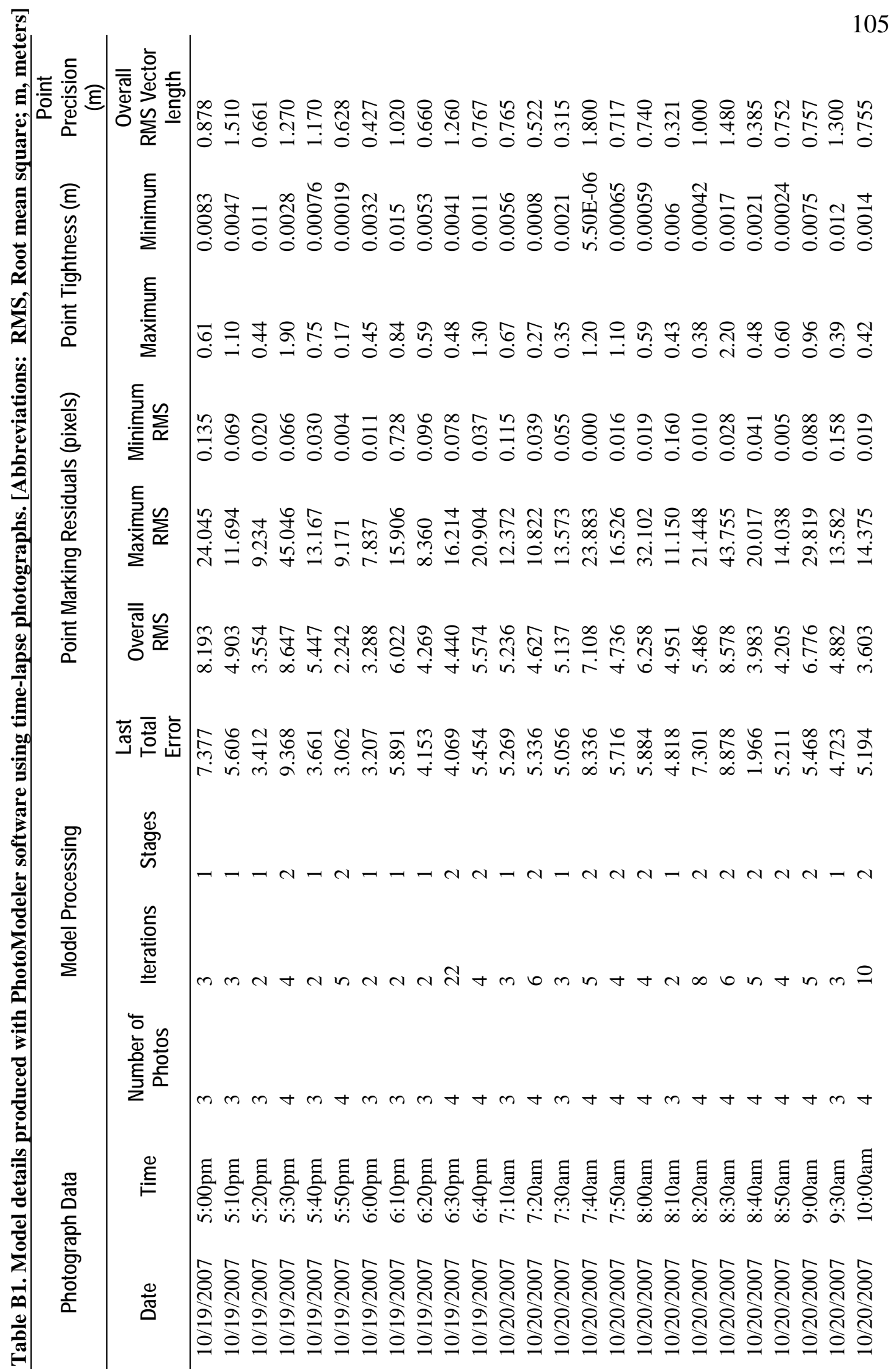




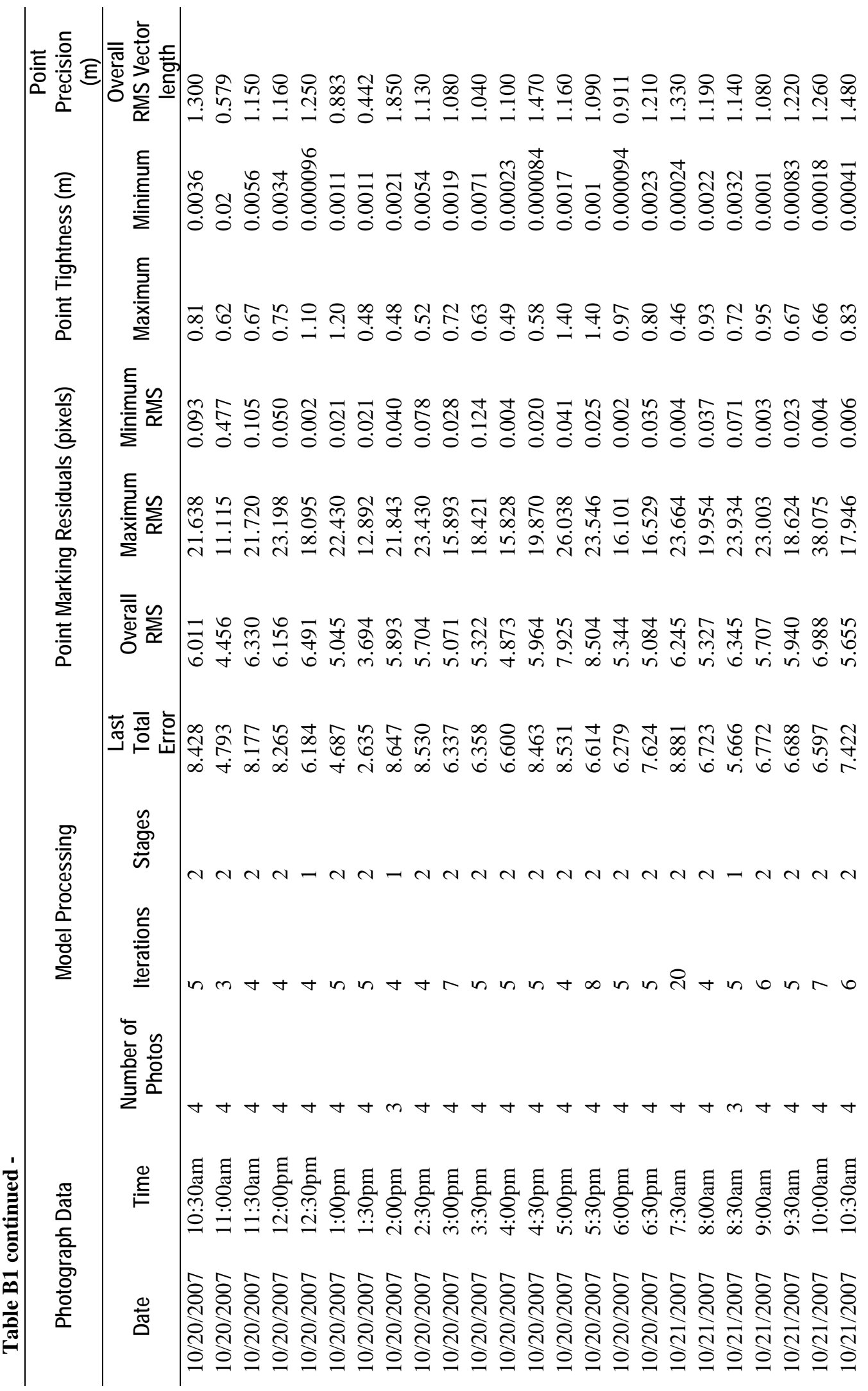




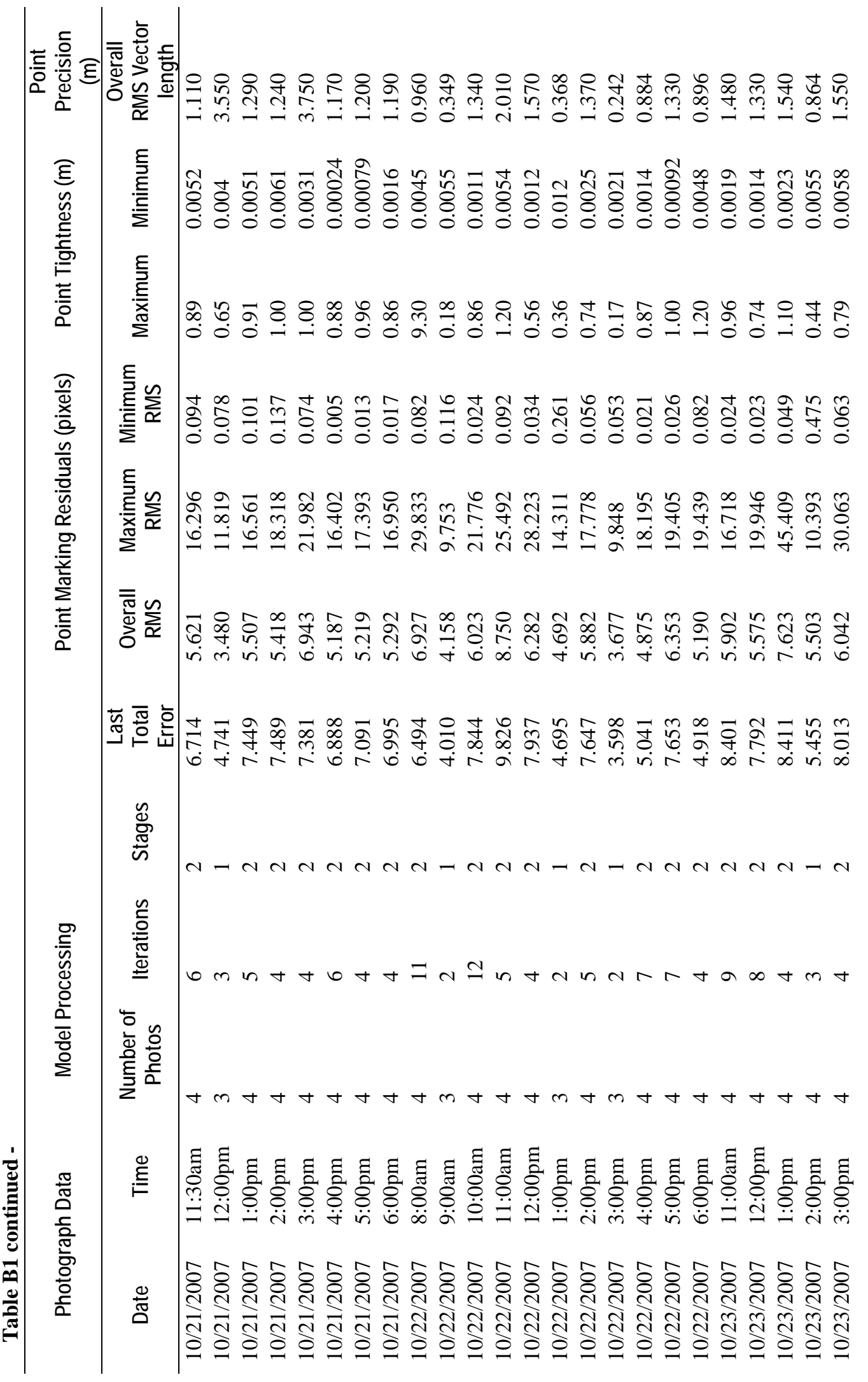




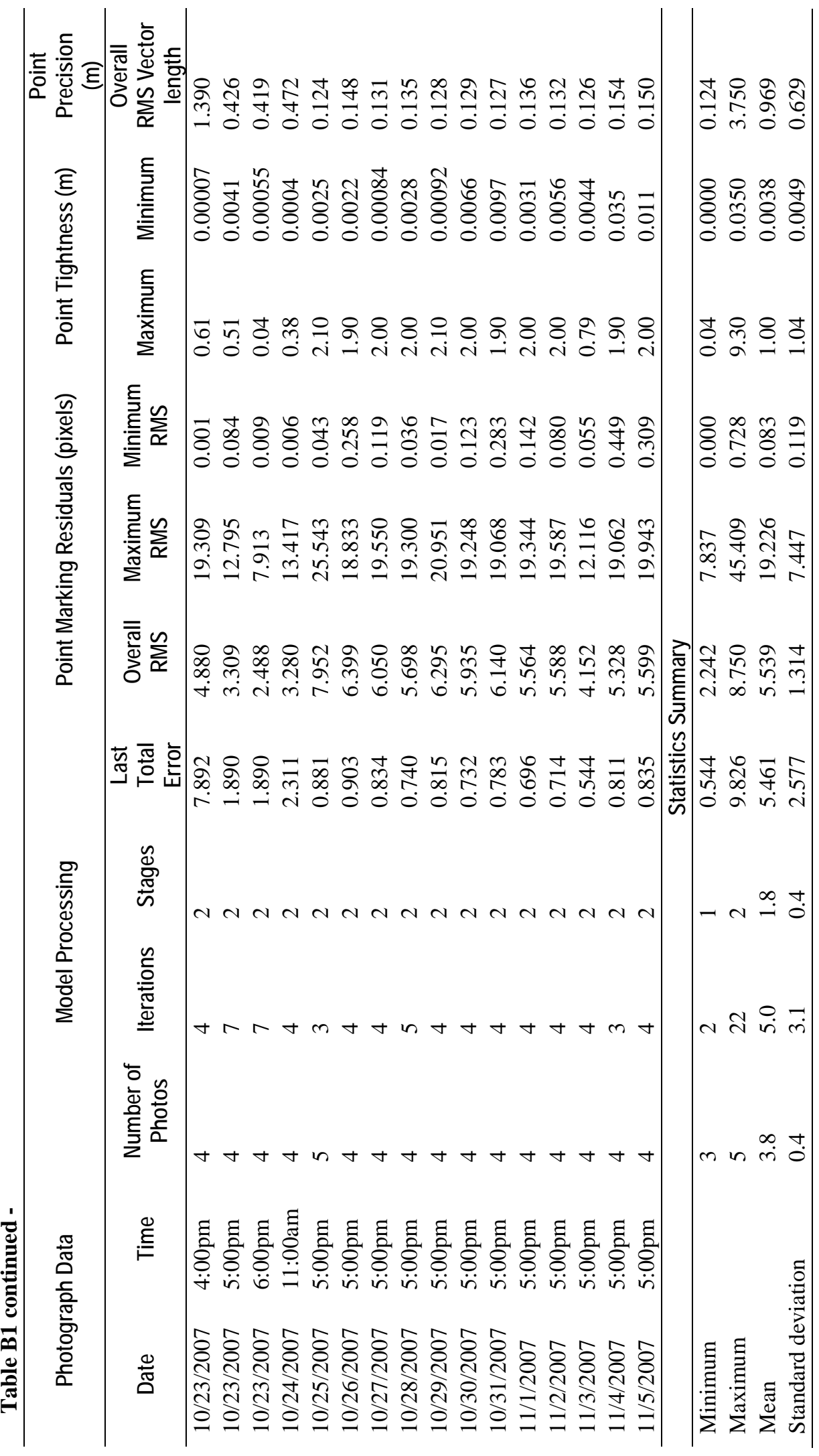


Appendix C. Grain sizes and statistics obtained from transects in the vicinity of Marmot Dam on the Sandy River, Oregon. 
Table C1. Surface grain size collection sites and summary. [Abbreviations: $D_{16}$, 16th percentile diameter; $D_{50}$, median diameter; $D_{84}, 84$ th percentile diameter; $D_{50 g}$, median diameter of gravel fraction]

\begin{tabular}{|c|c|c|c|c|c|c|c|c|c|c|}
\hline Transect & Date & $\begin{array}{c}\text { Number } \\
\text { of } \\
\text { Particles }\end{array}$ & Easting & Northing & $\begin{array}{l}\text { Height } \\
\text { Above } \\
\text { Channel, } \\
\text { in } \\
\text { meters* }\end{array}$ & $D_{16}$ & $\mathrm{D}_{50}$ & $\mathrm{D}_{84}$ & $\begin{array}{l}\text { Percent } \\
\text { Sand }\end{array}$ & $D_{50 \mathrm{~g}}$ \\
\hline A & $1 / 18 / 2008$ & 100 & 568408 & 5027498 & 6.52 & 0 & 0 & 2 & 86 & 3 \\
\hline B & $1 / 18 / 2008$ & 100 & 568386 & 5027489 & 5.33 & 1 & 79 & 177 & 19 & 101 \\
\hline C & $1 / 18 / 2008$ & 100 & 568370 & 5027497 & 2.78 & 23 & 135 & 246 & 7 & 148 \\
\hline Marmot1 & 2/26/2009 & 50 & 568293 & 5027153 & 5.00 & 0 & 45 & 180 & 38 & 88 \\
\hline Marmot2 & $2 / 26 / 2009$ & 30 & 567572 & 5027666 & 0.40 & 0 & 56 & 115 & 27 & 76 \\
\hline T1L & $10 / 25 / 2008$ & 101 & 568294 & 5027246 & 0.55 & 64 & 146 & 244 & 6 & 153 \\
\hline $\mathrm{T} 2 \mathrm{~L}$ & $10 / 27 / 2008$ & 101 & 568327 & 5027304 & 0.70 & 23 & 126 & 269 & 14 & 146 \\
\hline T3L & 10/27/2008 & 102 & 568370 & 5027395 & 0.06 & 51 & 156 & 291 & 4 & 161 \\
\hline T4R & $11 / 23 / 2008$ & 101 & 568176 & 5026995 & 1.00 & 1 & 71 & 162 & 21 & 97 \\
\hline T5R & $11 / 23 / 2008$ & 101 & 568254 & 5027124 & 4.30 & 0 & 43 & 149 & 37 & 95 \\
\hline T6R & $11 / 23 / 2009$ & 33 & 568291 & 5027153 & 5.69 & 1 & 34 & 69 & 18 & 46 \\
\hline T7Rd & 5/31/2009 & 101 & 567733 & 5027692 & 0.89 & 0 & 103 & 234 & 25 & 143 \\
\hline T8Rd & 5/31/2009 & 51 & 567749 & 5027685 & 0.17 & 48 & 111 & 220 & 4 & 114 \\
\hline T9Rd & 5/31/2009 & 100 & 567597 & 5027680 & 0.09 & 0 & 45 & 155 & 30 & 77 \\
\hline T10Rd & $6 / 12 / 2009$ & 100 & 567269 & 5027686 & 0.30 & 13 & 64 & 117 & 9 & 70 \\
\hline T11Rd & $6 / 12 / 2009$ & 102 & 566312 & 5027169 & 0.17 & 27 & 88 & 217 & 9 & 97 \\
\hline $\mathrm{T} 12 \mathrm{R}$ & 6/12/2009 & 102 & 566077 & 5027109 & 0.55 & 2 & 86 & 197 & 20 & 109 \\
\hline T13R & $6 / 12 / 2009$ & 102 & 566074 & 5027126 & 0.81 & 4 & 72 & 167 & 15 & 87 \\
\hline $\mathrm{VF}^{+}$ & 6/18/2009 & 187 & 568386 & $\sim 5027489$ & 4.40 & 5 & 53 & 161 & 6 & 59 \\
\hline $\mathrm{VF}^{+}$ & 6/18/2009 & 47 & 568386 & $\sim 5027489$ & 4.40 & 5 & 42 & 125 & 9 & 48 \\
\hline T14R & 4/3/2010 & 100 & 568376 & 5027546 & 4.60 & 1 & 19 & 195 & 0 & 19 \\
\hline
\end{tabular}

*Relative to the 2008 LiDAR water surface.

+Sample collected by NCED interns, near vertical face of surface where transect B was collected. 
Table C2. Surface grain size measurements in the vicinity of Marmot Dam following 19 October 2007 removal. [Abbreviations: $\mathrm{mm}$, millimeters]

\begin{tabular}{|c|c|c|c|c|c|c|c|c|c|c|c|c|c|c|c|c|c|c|}
\hline \multirow[t]{2}{*}{ Transect } & \multicolumn{18}{|c|}{ Percent Finer, sizes in $\mathrm{mm}$} \\
\hline & 2 & 2.8 & 4 & 5.6 & 8 & 11 & 16 & 22.6 & 32 & 45 & 64 & 90 & 128 & 180 & 256 & 360 & 51210 & \\
\hline$\overline{\mathrm{A}}$ & 86 & 0 & 11 & 1 & 2 & 0 & 0 & 0 & 0 & 0 & 0 & 0 & 0 & 0 & 0 & 0 & 0 & $\overline{0}$ \\
\hline B & 19 & 0 & 1 & 1 & 0 & 1 & 2 & 3 & 4 & 5 & 5 & 15 & 11 & 18 & 14 & 1 & 0 & 0 \\
\hline C & 7 & 4 & 0 & 0 & 0 & 1 & 3 & 0 & 2 & 2 & 4 & 7 & 18 & 13 & 26 & 12 & 1 & 0 \\
\hline Marmot1 & 19 & 0 & 0 & 0 & 1 & 0 & 0 & 1 & 2 & 2 & 3 & 7 & 4 & 3 & 3 & 5 & 0 & 0 \\
\hline Marmot2 & 8 & 0 & 0 & 0 & 0 & 0 & 0 & 1 & 0 & 3 & 5 & 4 & 6 & 2 & 1 & 0 & 0 & 0 \\
\hline $\mathrm{T} 1 \mathrm{~L}$ & 6 & 0 & 0 & 0 & 1 & 0 & 1 & 0 & 0 & 2 & 6 & 10 & 16 & 22 & 24 & 10 & 2 & 1 \\
\hline T2L & 14 & 0 & 0 & 0 & 0 & 0 & 0 & 2 & 2 & 4 & 9 & 9 & 11 & 17 & 15 & 13 & 5 & 0 \\
\hline T3L & 4 & 0 & 0 & 0 & 1 & 0 & 0 & 3 & 2 & 4 & 7 & 6 & 12 & 21 & 19 & 18 & 4 & 1 \\
\hline T4R & 21 & 0 & 1 & 1 & 0 & 0 & 1 & 1 & 1 & 8 & 13 & 11 & 15 & 17 & 8 & 2 & 1 & 0 \\
\hline T5R & 37 & 0 & 1 & 0 & 0 & 1 & 2 & 2 & 4 & 4 & 4 & 12 & 13 & 11 & 7 & 3 & 0 & 0 \\
\hline T6R & 6 & 0 & 1 & 1 & 0 & 0 & 2 & 2 & 4 & 3 & 8 & 3 & 3 & 0 & 0 & 0 & 0 & 0 \\
\hline T7Rd & 25 & 0 & 0 & 0 & 0 & 0 & 1 & 0 & 1 & 7 & 7 & 5 & 12 & 15 & 16 & 10 & 2 & 0 \\
\hline T8Rd & 2 & 0 & 0 & 0 & 0 & 0 & 0 & 1 & 1 & 3 & 6 & 6 & 11 & 10 & 5 & 5 & 1 & 0 \\
\hline T9Rd & 30 & 0 & 2 & 0 & 3 & 1 & 2 & 2 & 6 & 4 & 10 & 9 & 10 & 9 & 10 & 1 & 1 & 0 \\
\hline T10Rd & 9 & 0 & 1 & 0 & 0 & 0 & 0 & 9 & 7 & 16 & 8 & 16 & 24 & 10 & 0 & 0 & 0 & 0 \\
\hline T11Rd & 9 & 0 & 0 & 0 & 1 & 0 & 1 & 3 & 5 & 7 & 12 & 14 & 17 & 13 & 7 & 7 & 4 & 2 \\
\hline T12R & 20 & 0 & 0 & 0 & 1 & 0 & 0 & 3 & 3 & 4 & 9 & 12 & 16 & 14 & 11 & 5 & 3 & 0 \\
\hline T13R & 15 & 0 & 0 & 0 & 0 & 0 & 0 & 4 & 5 & 10 & 12 & 14 & 11 & 19 & 9 & 1 & 1 & 1 \\
\hline T14R & 0 & 19 & 11 & 9 & 4 & 5 & 0 & 0 & 4 & 2 & 3 & 2 & 8 & 14 & 13 & 6 & 0 & 0 \\
\hline
\end{tabular}

